Florida International University

FIU Digital Commons

FIU Electronic Theses and Dissertations

University Graduate School

3-30-2018

\title{
Promoting Healthy Eating Habits and Physical Activity among School-aged Children in Kuwait - "My Healthy Habits" Summer Camp
}

Ghanima Alabdullah

galab001@fiu.edu

DOI: 10.25148 /etd.FIDC006544

Follow this and additional works at: https://digitalcommons.fiu.edu/etd

Part of the International and Community Nutrition Commons

\section{Recommended Citation}

Alabdullah, Ghanima, "Promoting Healthy Eating Habits and Physical Activity among School-aged Children in Kuwait - "My Healthy Habits" Summer Camp" (2018). FIU Electronic Theses and Dissertations. 3704.

https://digitalcommons.fiu.edu/etd/3704

This work is brought to you for free and open access by the University Graduate School at FIU Digital Commons. It has been accepted for inclusion in FIU Electronic Theses and Dissertations by an authorized administrator of FIU Digital Commons. For more information, please contact dcc@fiu.edu. 


\section{FLORIDA INTERNATIONAL UNIVERSITY}

Miami, Florida

PROMOTING HEALTHY EATING HABITS AND PHYSICAL ACTIVITY AMONG SCHOOL-AGED CHILDREN IN KUWAIT - "MY HEALTHY HABITS" SUMMER CAMP

A dissertation submitted in partial fulfillment of the requirements for the degree of DOCTOR OF PHILOSOPHY

in DIETETICS AND NUTRITION

by

Ghanima Alabdullah 
To: Dean Tomás R. Guilarte

Stempel College of Public Health and Social Work

This dissertation, written by Ghanima Alabdullah, and entitled Promoting Healthy Eating Habits and Physical Activity among School-aged Children in Kuwait - "My Healthy Habits" Summer Camp, having been approved in respect to style and intellectual content, is referred to you for judgment.

We have read this dissertation and recommend that it be approved.

$\begin{array}{r}\hline \text { Catherine Coccia } \\ \hline \text { Adriana Campa } \\ \hline \text { Florence George } \\ \hline \text { Lamia Shaban } \\ \hline \text { Fatma G. Huffman, Major Professor }\end{array}$

Date of Defense: March 30, 2018

The dissertation of Ghanima Alabdullah is approved.

Dean Tomás R. Guilarte Stempel College of Public Health and Social Work

Andrés G. Gil Vice President for Research and Economic Development And Dean of the University Graduate School

Florida International University, 2018 
(c) Copyright 2018 by Ghanima Alabdullah

All rights reserved. 


\section{DEDICATION}

This dissertation is dedicated to everyone that supported me to make this dissertation possible. Special thanks to my husband Waleed for being there for me to give me support and making it possible even from thousands of miles away. Thanks also goes to my father Abdullrazag for his continue support and making sure that I have a decent life. Thanks to my mother who was here for me taking care of me and my kids. Thanks to my brothers and sisters for being part of this Journey. Thanks to my mother in law Modi and my sister in law Maryam for sharing this journey. Last but not least, thanks go to my children Saqer and Dana for being with me and sharing this beautiful experience. 


\section{ACKNOWLEDGMENTS}

I would like to thank my committee members for their guidance from the beginning of the proposal until I completed this dissertation. Special thanks go to my major professor Dr. Fatma Huffman for making this achievable and her continue support since I started my PhD degree. Thanks to Dr. Adriana Campa and Dr. Catherine Coccia for working on making this dissertation as best as possible. Thank you, Dr. Florence George, for your statistical advice to get the best out of the data, and thanks to Dr. Lamia Shaban for facilitating the research process in Kuwait. I also want to thank the participating summer camps; My Gym and Little Gym for providing space and facilitating the recruitment process. I also want to thank Reem AlAwadhi for volunteering in data collection. Finally, I want to thank Kuwait ministry of Health and Food and Nutrition department for providing a scholarship for my education in the USA. 


\begin{abstract}
OF THE DISSERTATION
PROMOTING HEALTHY EATING HABITS AND PHYSICAL ACTIVITY AMONG

SCHOOL-AGED CHILDREN IN KUWAIT - "MY HEALTHY HABITS” SUMMER

CAMP

by
\end{abstract}

Ghanima Alabdullah

Florida International University, 2018

Miami, Florida

Professor Fatma G. Huffman, Major Professor

The effectiveness of an eight-week nutrition and physical activity intervention at a summer camp to prevent obesity, and promote healthy eating habits and physical activity among children in Kuwait was studied. Two summer camps were recruited for intervention and comparison groups. Convenient sampling was used $(\mathrm{N}=79)$. Pretest/post-test assessment were used for the participants in the intervention and comparison groups. Modified Healthy Habits Survey (HHS) was used to measure children's knowledge, behavior and attitude about nutrition, screen time and physical activities, BMI-for age percentile were collected. Statistical analysis included independent t-test, paired t-test, chi-squared test, McNemar's test, and multiple regression. Results indicated that there was a significant increase in nutrition knowledge score $(\mathrm{P}<0.001)$ in intervention group. There was a significant increase in the number of servings of healthy foods: significant increases in dairy, fruits, vegetables, whole grains, and protein consumption were observed $(p=0.013, p=0.007,<0.001, p=0.002$, and $p=$ 0.012 , respectively). There was no significant decrease in the number of servings of 
unhealthy foods for french-fries and chips, fruit flavored drinks or soft drinks. The only significant decrease in the unhealthy food intake was seen in the number of servings of sweets and candies. Thirty-three-point-three percent of participants in the intervention group decreased their consumption of sweets and candies to 1 time or less per day $(\mathrm{P}=0.001)$. There was a significant increase in the intervention group in both physical activity and screen time knowledge $(\mathrm{P}<0.001)$ and behavior related to screen viewing and physical activities $(p<0.001)$. The participants BMI and Waist-to-height ratio decreased significantly in the intervention group $(\mathrm{p}=0.001)$. The regression analysis showed that neither age nor gender had an effect on the participants BMI. The results of this study indicate that eight weeks of "My Healthy Habits" summer camp was affective in improving nutrition, physical activity, and screen time knowledge and behavior. To prevent childhood overweight and obesity summer camps may be a good venue in Kuwait. Long-term follow-up is recommended to check the sustainability of these results. 


\section{TABLE OF CONTENTS}

CHAPTER

PAGE

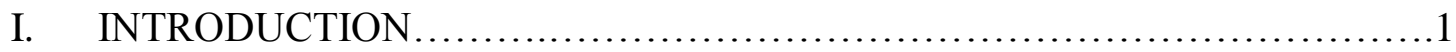

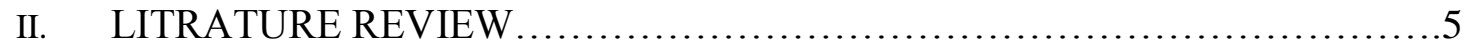

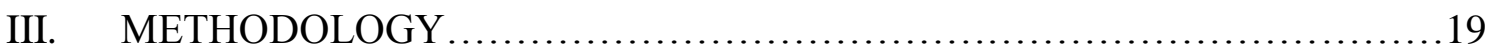

IV. The effect of "My Healthy Habits" summer camp on improving the participant's nutrition knowledge and behavior ....................................................26

V. The effect of "My Healthy Habits" summer camp on improving the participant's physical activity level and screen time

VI. The effect of My Healthy Habits summer camp on the participants BMI percentile and Waist-to-Height ratio.

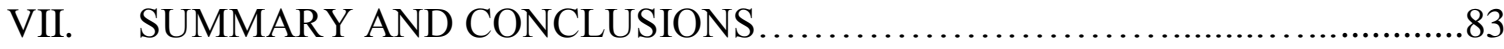

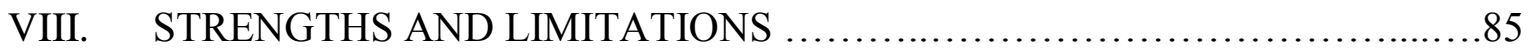

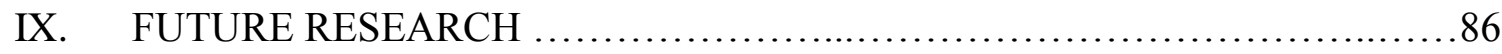

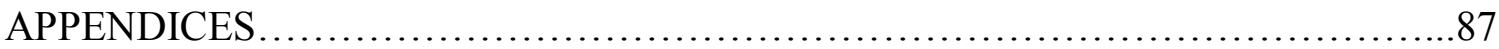

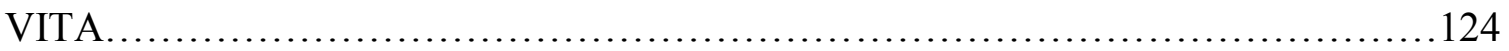




\section{LIST OF TABLES AND GRAPHS}

TABLE

PAGE

CHAPTER II

1. Children's baseline demographic characteristics by treatment group ...............39

2. Mothers' baseline demographic characteristics by treatment group ............39

3. Participants nutritional knowledge and behavior at baseline and postintervention.

CHAPTER III

1. Children's baseline demographic characteristics by treatment group

2. Mothers' baseline demographic characteristics by treatment group

3. Participants knowledge and behavior related to physical activity and screen time at baseline and post-intervention

\section{CHAPTER IV}

1. Children's baseline demographic characteristics by treatment group

2. Mothers' baseline demographic characteristics by treatment group ...........76

3. Anthropometric measurements by treatment group at baseline and postintervention.

4. Distributions of subjects' BMI category, pre- and post-intervention in comparison and intervention groups

5. Distributions of subjects' central obesity, pre- and post-intervention in comparison and intervention groups.

6. The effect of age and gender on participants BMI percentile

7. BMI percentile difference before and after intervention between intervention and comparison groups (graph) 


\section{ABBREVIATIONS AND ACRONYMS}

$\begin{array}{ll}\text { BMI } & \text { Body Mass Index } \\ \text { BMIz } & \text { Body Mass Index z-score } \\ \text { CATCH } & \text { Coordinated Approach to Child Health } \\ \text { CDC } & \text { Center for Disease Control and Prevention } \\ \text { CKC } & \text { Catch Kids Club } \\ \text { FIU } & \text { Florida International University } \\ \text { HHS } & \text { Healthy Habits Survey } \\ \text { IRB } & \text { Institutional Review Board } \\ \text { MVPA } & \text { Moderate to Vigorous Physical Activity } \\ \text { WHtR } & \text { Waist-to-height ratio }\end{array}$




\section{CHAPTER I: INTRODUCTION}

\section{Statement of Problem:}

The prevalence of overweight and obesity has increased rapidly worldwide.

Overweight/obesity is defined as having excess body fat that affects the persons health (WHO, 2017). The WHO considers childhood obesity to be a global epidemic (Wang, Wu, Wilson, Bleich, Cheskin, et al., 2013). In Kuwait, the Nutrition Surveillance System (2011) showed that $16 \%$ of boys aged 5 - 9 years and $11 \%$ of the girls are obese for the same age group (Alsumaie, 2011). The harsh climate of Kuwait, the abundance and buying power of food and technology have led to an overconsumption of food and sedentary lifestyle, which all contributed to the increase of the prevalence of obesity (Kuwait Nutrition Profile, 2006).

Based on the review of the scientific evidence, theWHO developed recommendations to combat childhood obesity. These recommendations are to: 1) promote intake of healthy foods and reduce intake of unhealthy foods and sugarsweetened beverages, 2) promote physical activity and reduce sedentary behaviors, 3) provide a healthy school environment, and nutrition and physical activity education, and 4) provide family-based weight management services for obese children (WHO, 2016). After-school, summer-camps, and child-care programs offer opportunities to deliver these recommendations in a convenient setting for the participants (Kelder, Hoelscher, Barroso, Walker, Cribb, et al., 2005). 


\section{Significance:}

Child obesity is an area of research that is important due to its relationship with nutrition related chronic diseases (Dudley, Cotton, \& Peralta, 2015). Healthy eating is very important in school age children for their optimal growth, to build healthy bodies, strong bones, and strong immunity (Dudley, et al., 2015). The importance of establishing healthy eating habits early as these habits tend to grow up with the children into adulthood need to be emphasized (Neumark-Sztainer, Wall, Larson, Eisenberg, Loth, 2011; Nicklaus, \& Remy, 2013).

Although school intervention programs aimed to reduce obesity in children have been developed in the United States and Europe, to our knowledge no known after school or summer camp programs focused on obesity reduction in Kuwait. The literature provided strong evidence on the effectiveness of summer-camp interventions on creating a suitable environment to expose children to healthy lifestyle including healthy eating habits and physical activities.

\section{Specific Aims and Hypotheses}

\section{Specific Aim 1}

To assess the effectiveness of an eight-week intervention at a summer camp on increasing the participant's nutrition knowledge and behavior related to healthy food consumption of fruits, vegetables, whole grains, dairy and lean proteins, and reduce the unhealthy food consumption of sugary beverages, sodas, sweets, fries, or chips.

\section{Hypothesis 1}

H1a. The intervention will produce significant changes in participant's 
nutrition knowledge including higher score of mean nutrition knowledge as compared to baseline and the comparison group.

H1b. The intervention will produce significant changes in participant's nutrition behavior including more servings of fruits, vegetables, whole grains, dairy, and lean proteins as compared to baseline and the comparison group.

H1c. The intervention will produce significant changes in participant's nutrition behavior including less servings of sugary beverages and soda, sweets and chips as compared to baseline and the comparison group.

\section{Specific Aim 2}

To assess the effectiveness of an eight-week intervention at a summer camp on increasing the participant's physical activity level and decreasing the participant's screen time and increasing physical activity and screen time knowledge.

\section{Hypothesis 2}

H2a. The intervention will produce significant changes in the participant's time spent on physical activities as compared to baseline and the comparison group.

H2b. The intervention will produce significant changes in the participant's physical activity knowledge, including higher score of physical activity knowledge as compared to baseline and the comparison group.

H2c. The intervention will produce significant changes in children's screen time, including less screen time as compared to baseline and the comparison group.

H2d. The intervention will produce significant changes in children's screen time knowledge, including higher score of screen time knowledge as compared to baseline and the comparison group. 


\section{Specific Aim 3}

To assess the effectiveness of an eight-week intervention at a summer camp on preventing increase in weight percentile and waist-to-height ratio of the participants.

\section{Hypothesis 3}

H3a. The intervention will prevent increase in children's Waist-to-height ratio as compared to baseline and the comparison group.

$\mathrm{H} 3 \mathrm{~b}$. The intervention will prevent increase in children's BMI percentile as compared to baseline and the comparison group. 


\section{CHAPTER II: LITRATURE REVIEW}

\section{Childhood obesity and educational lessons:}

"Educació en Alimentació" is an afterschool educational intervention conducted by Tarro et al. (2014) to investigate the effect of this intervention on promoting healthy eating habits and physical activities among elementary school children. It showed a successful reduction in boys' childhood obesity prevalence in a school based setting. The study involved 1,222 Students from 24 elementary schools in the intervention group, and 717 from 14 elementary schools in the control group. Data collection included BMI collected annually for 3 consecutive years, dietary habits and lifestyle questionnaire were filled by the parents at baseline and at the end of the study. The intervention included 12 activities (1 hour/activity/session) applied by health promoting agents for three academic years. The intervention resulted in a reduction in the boy's obesity prevalence by $2.36 \%$ (from $9.59 \%$ to $7.23 \%$ ) while it increased in the control group by $2.03 \%$ (from $7.4 \%$ to $9.43 \%)$ with a difference of $4.39 \%(p=0.01)$ between the 2 groups. The prevalence of obesity in the girls remained the same. An explanation of the research was that physiological differences between the two genders that girl's puberty is earlier than the boys. In addition, $5.1 \%$ more students in the intervention group participated in PA $>5$ hours/ week than the control group $(p=0.02)$. The results also showed that fast food consumption was a risk factor for obesity (odds ratio: 2.27; 95\% CI 1.08 to 4.77), while fish consumption was a protective factor (odds ratio $0.39 ; 95 \%$ CI 0.23 to 0.67 ) (Tarro, Llauradó, Albaladejo, Moriña, Arija, et al., 2014). 
"SWITCH" is a community, school, and family based intervention that aimed to change behaviors related to childhood obesity by following Socio ecological model for eight months. These behaviors include physical activity, screen time, and nutrition. Ten schools from Lakeville, Minnesota and Cedar Rapids, Iowa were randomly selected and assigned to intervention or control schools. The intervention consisted of four phases. In the first phase, the child with the help of his/her parent establish a baseline to identify current health behavior practices and evaluate attitude and feelings in making a change in physical activity, screen, and nutrition. Then, they establish short- and long-term goals. The second phase focuses on making these changes by enforcement through rewards with activity or goal points. The third phase was to provide motivations and tools to make it easier for families to prepare healthy meals and snacks. The last phase was to maintain behavior change established during the intervention. Children knowledge regarding nutrition, food choices, and physical activity was improved

(Eisenmann et al., 2008; Gentile et al., 2009).

\section{Childhood obesity and physical activity:}

Following "Healthy Schools" project that is developed by WHO for European countries, a two-year non-randomized longitudinal intervention study in the Czech Republic by Sigmund et al. (2012) involved students from four elementary schools (two schools were in the intervention and two in control, $n=176)$. The purpose was to test whether involving in physical activities within the school setting can decrease overweight and obesity in 6-9-year-old children. The PA levels were monitored using pedometers (step counts) and Caltrac accelerometer (activity energy expenditure AEE - kcal/kg 
bodyweight per day). The study showed significant increase in PA in intervention group compared to the control group. Increase in PA in school has positively impacted children's free time during the weekends by increasing PA. The odds of being overweight or obese in the intervention group was three times lower than the control group $(p<$ 0.005). Showing that the school based PA was affective in overweight and obesity reduction among elementary school children (Sigmund, El Ansari, \& Sigmundová, 2012).

\section{Childhood obesity and nutrition behavior:}

"Fresh Fruit and Vegetable" program was created by USDA to reduce the prevalence of childhood overweight and obesity and improve childhood nutrition through providing free fresh fruits and vegetables for the participants in the program and study their behavior and attitude regarding eating fruits and vegetables through pre-test and post- test survey. Nutrition education to promote fruit and vegetable consumption was also included. The study involved 784 participants from 10 intervention schools, and 343

participant from 10 control schools. All participants were in the $4^{\text {th }} 7^{\text {th }}$, or $9^{\text {th }}$ grades. The result reported that students' willingness to try new fruits and vegetables at school has increased significantly ( $\mathrm{p}$ < 0.01) (Jamelske, Bica, McCarty, Meinen, 2008).

Anand et al. (2007) initiated a 6-month family based randomized control trial to promote healthy lifestyle in Canadian children (kindergarten to 12-grade). One hundred seventy-four participants were randomized to intervention or usual care. The intervention included health education, physical activity, increasing water and low-fat milk consumption, and reducing consumption of sugary drinks. Significant reductions in fats, oils, and sweets were seen in the intervention group compared to the usual care group ( $p$ 
$=0.006)$, reduction in trans fatty acids $(p=0.02)$, increase in water consumption $(p$ $<0.04)$, and decrease in sugary drinks $(p=0.02)$ were also observed. A trend in children's nutrition knowledge and physical activity was observed although it was not significant (Anand, et al., 2007).

\section{Childhood obesity, nutrition education and physical activity:}

"Kids Living Fit" is a hospital based community program focusing on fitness and nutrition education to assess the impact of the intervention on the participant's weight for overweight children. In respond to an advertisement to participate in the intervention, a convenience sample of children between the second and fifth grades were used to include 185 participants (80 in the intervention group, and 105 in the control group). For 24 weeks, the participants recorded daily diaries of food and activities, they received weekly exercise programs, and monthly nutrition education. Pedometers were also used to assess physical activity, and BMI percentile and waist circumference to assess weight change. The intervention resulted in significant reduction in mean BMI $(2.4 \%, p<0.01)$ in the intervention group compared with significant increase in mean BMI $(1.5 \%, p<0.05)$ in the control group (Speroni, Tea, Earley, Niehoff, \& Atherton, 2008).

"Healthy Lifestyle" school based intervention was conducted in four elementary schools in Kentucky. The intervention included health education, improving physical education, family/community involvement, and school wellness policies. To assess if the intervention was successful, pedometers were used to assess physical activities and 24hour recalls were used to assess the participant's nutritional status. Positive effect was 
seen in physical activity $(p<0.01)$ and nutritional status $(p<0.01)$ among the participants (Ling, King, Speck, Kim, \& Wu, 2014).

“Healthy Opportunity for PA and Nutrition” (HOP’N) is an after-school program that focuses on preventing childhood obesity through increasing the opportunity for PA and intake of fruits and vegetables. Dzewaltowski et al. (2010) conducted a 3-year nested cross-sectional group randomized, controlled trial on HOP'N with 4 intervention schools and 3 control schools to have a total sample size of 961 . HOP'N was provided with Coordinate Approach to Child's Health (CATCH) Kids Club curriculum to help the program implementers to follow CATCH Kids Club guidelines. It involved daily 30 min of PA that followed by CATCH activity box, daily healthy snack, and weekly nutrition and PA education provided in the curriculum. BMI z-scores was measured for the participants, physical activity levels, and observations of the intervention. However, there was no significant difference in BMI z-score or number of fruits and vegetables intakes. However, a significant increase in moderate-to-vigorous physical activity (MVPA) was observed. HOP'N was successful in increasing PA in after school time (Dzewaltowski, Rosenkranz, Geller, Coleman, Welk, et al. 2010).

"Active Generation" is another intervention program that aimed in preventing childhood obesity. This program focused on nutrition education and physical activity in after school and summer camp settings by implementing $\mathrm{CATCH}$ program in eight cities in the United States. Werner et al. (2012) studied 760 elementary school participants in "Active Generation" program. Which was implemented in recreation facilities, parks, and community centers. The intervention included ten interactive discussions following CATCH curriculum. Active generation also included nutrition education, activities, and 
snack preparation, and the physical activity part included 30-minute fun, active cardio games. The participants completed Active Generation Survey in the first and last day of the intervention to assess their knowledge, attitude, and beliefs about nutrition, physical activity, and media use. The study found significant increase in the participant's fruit and vegetable consumption, in reading food labels, participation in physical activities, and significant decrease in screen time (Werner, Teufel, Holtgrave, \& Brown, 2012).

\section{Childhood obesity and family involvement:}

According to a systematic review by Almarzooqi and Nagy (2011), six studies from six different countries around the world involved the parents and their children's behavior change. All of the studies showed positive significant outcomes in children's BMI, diet and physical activities. Childhood obesity prevention programs involving parents had more significant outcomes than childhood obesity prevention programs that did not involve the parents (Almarzooqi, \& Nagy, 2011).

\section{Childhood obesity intervention in summer camps:}

The Children's Health and Activity Modification Program "C.H.A.M.P.” is a community based intervention program that targets obese children (age 5-14 years old). Thirty-six obese children and their families were recruited through advertisement placed in several places in the community. In this program, the participants completed a 4-week group-based physical activity, dietary, and behavior modification intervention for the children, and educational classes for the families covering similar topics covered by the children's part of the intervention. The intervention resulted in significant decrease in 
childrens BMI-z score and fat mass $(p<0.05)$, significant muscle mass increase $(p<$ 0.05 ) from baseline to post-intervention. Children's self-reported physical and emotional Quality of Life (QOL) increased significantly $(p<0.05)$ from baseline to postintervention as well as parent's perception of their child's physical, emotional, and social QOL $(p<0.05)$ (Burke, et al., 2015).

An 8-week summer camp intervention program in Massachusetts, USA was designed to introduce fun skill learning on moderate dietary restriction, behavioral modification, and physical activities among overweight and obese children $(n=194)$. The study resulted in significant reduction in BMI $(p<0.01)$ suggesting that summer camps can be an effective venue to change the children perception about healthy eating and exercise (Gately, Cooke, Butterly, Mackreth, \& Carroll, 2000).

A 6-week randomized controlled trial was designed as a summer camp intervention that is conducted for overweight and obese children. The intervention focuses on increasing physical activity and following a healthy diet. The intervention resulted in significant improvement in BMI- z score, clustered cardiovascular risk zscore, and body composition ( $p<0.001)$ (Larsen, et al., 2016).

The "Healthy Lifestyle Fitness Camp" (HLFC) is a free community-based summer camp designed to prevent obesity in children aged 9-14 years old. To test the effectiveness of this program in reducing overweight and obesity in children, 126 overweight and obese children participated in a 6-week quasi-experimental intervention. The program for the intervention group involved 3 hours of daily physical activities, and 3 hours weekly nutrition education. While the control group attended another camp that was not related to nutrition or physical activity. Children's body weight, waist 
circumference, and waist to height ratio before and after intervention noted to examine the differences between the two groups. Significant differences were detected in all three measurements between intervention and control groups $(p<0.001, p<0.02, p<0.001$; respectively) (George, Schneider, \& Kaiser, 2016).

Qingya et al. (2014) investigated the effect of a summer camp program of diet and physical activity to manage childhood obesity in Shanghai. Twenty obese children aged 7 to 17 years participated in a 4-week summer camp that included energy restricted but nutritionally complete diet plan and four sessions of 45 minutes of daily physical activities. The study resulted in a significantly reduction in bodyweight, fat mass, waist circumference, waist to hip ratio, and abdominal fat $(p<0.01)$. The intervention was also affective in significant reducing uric acid, total cholesterol, triglycerides, LDL, HbA1C, insulin, C-peptide and insulin resistance $(p<0.01)$ (Qingya, et al., 2014).

Cooper et al. (2006) measured the outcome of a 4-week summer camp intervention for obese children repeated for three summers. The camp included diet management, daily physical activity, nutrition education, and weekly psychology classes. The intervention resulted in average weight loss of $1.6 \mathrm{~kg} / \mathrm{week}$, and decreased waist circumference by $8.1 \pm 5.8 \mathrm{~cm}$ (Cooper, et al., 2006).

Gately et al. (2005) evaluated the effectiveness of a summer camp designed for overweight and obese children. One hundred eighty five overweight children (mean age 13.9 years old) participated in a 6-week summer camp were compared to 94 children (at the same age) not attending summer camp. The comparison group was divided into two comparison groups according to the child's weight status (38 overweight and 56 normal weight). The intervention included daily physical activity, moderate dietary restriction, 
and nutrition education. The intervention resulted in significant reduction in all of the anthropometric measurements (BMI, percentage of body fat, waist and hip circumferences; $p<0.001)$ compared to both control groups. Improvement in aerobic fitness was significant for the intervention group $(p<0.001)$ and it was accompanied with significant reduction for both systolic and diastolic blood pressure $(p<0.001)$ (Gately, et al., 2005).

\section{Social cognitive theory (SCT):}

Social Cognitive Theory was the most used theory for interventions focusing on childhood obesity. It emphasizes on factors affecting children behaviors such as screen time, physical activity, and eating habits. In addition, several childhood obesity interventions following the SCT has been shown to be affective in improving nutrition behaviors and increasing physical activities (Hall, Chai, Koszewski, \& Albrecht, 2015). SCT will be used to design the intervention components to achieve the desired behavior. It is based on the idea that behavior change result from the dynamic interactions between individuals and their environments (Bandura, 1993).

\begin{tabular}{|l|l|l|l|}
\hline \multicolumn{2}{|c|}{ SCT key concept } & \multicolumn{1}{c|}{ Definition } & Intervention Component \\
\hline \multirow{2}{*}{$\begin{array}{l}\text { Psychological } \\
\text { determinates of } \\
\text { behavior }\end{array}$} & $\begin{array}{l}\text { Outcome } \\
\text { expectations }\end{array}$ & $\begin{array}{l}\text { Beliefs about the benefits } \\
\text { desired behavior }\end{array}$ & $\begin{array}{l}\text { Demonstration the benefits of he } \\
\text { eating and physical activities. }\end{array}$ \\
\cline { 2 - 4 } & Self-efficacy & $\begin{array}{l}\text { Heliefs about the ability to } \\
\text { perform the desired behavi } \\
\text { children self-efficacy that they c } \\
\text { perform the desired behavior (e. } \\
\text { preparation of healthy snack) }\end{array}$ \\
\hline & learning how to perform a & \begin{tabular}{l} 
Children will learn healthy eatin \\
\hline
\end{tabular}
\end{tabular}




\begin{tabular}{|l|l|l|l|}
\hline \multicolumn{2}{|l|}{ Observational learning } & $\begin{array}{l}\text { behavior by observing how } \\
\text { behavior is performed }\end{array}$ & $\begin{array}{l}\text { physical activities by observing } \\
\text { investigator, their peers, and } \\
\text { caregivers. }\end{array}$ \\
\hline \multirow{2}{*}{$\begin{array}{l}\text { Environmental } \\
\text { determinates of } \\
\text { behavior }\end{array}$} & motivation & $\begin{array}{l}\text { The use of rewards and } \\
\text { punishment to change a be }\end{array}$ & $\begin{array}{l}\text { Treasure box will be used to } \\
\text { encourage the children to perforn } \\
\text { desired behavior. }\end{array}$ \\
\cline { 2 - 4 } & Facilitation & $\begin{array}{l}\text { le tools, resources, and } \\
\text { environmental changes tha } \\
\text { help in performing the desi } \\
\text { behavior }\end{array}$ & $\begin{array}{l}\text { Commutation with caregivers to } \\
\text { facilitate the performance of the } \\
\text { desired behavior such as availab } \\
\text { of healthy food and opportunity } \\
\text { physical activities. }\end{array}$ \\
\hline \multirow{2}{*}{ Self-regulation } & $\begin{array}{l}\text { monitoring self through } \\
\text { feedback, self-instruction, } \\
\text { setting, self-reward, and so } \\
\text { support }\end{array}$ & $\begin{array}{l}\text { Check list after each session to } \\
\text { regulate self to reach the desired } \\
\text { (e.g. number of fruits eaten }\end{array}$ \\
\hline
\end{tabular}

\section{References}

Almarzooqi, M. A., \& Nagy, M. C. (2011). Childhood Obesity Intervention Programs: A Systematic Review. Life Science Journal, 8(4), 45-60. 
Alsumaie, M. (2011, March). The Kuwait nutrition surveillance system (KNSS): an example for the region. Speech presented at Ibn Khaldoon Hall. Qatar.

Anand, S.S., Davis, A.D., Ahmed, R., Jacobs, R., Xie, C., Hill, A., .. Yusuf S. (2007). A family-based intervention to promote healthy lifestyles in an aboriginal community in Canada. Canadian Journal of Public Health, 98(6), 447-452.

Bandura, A. (1993). Social foundations of thought and action: A social cognitive theory. Englewood Cliffs, NJ: Prentice-Hall.

Burke, S. M., Shapiro, S., Petrella, R. J., Irwin, J. D., Jackman, M., Pearson, E. S., ... Shoemaker, J. K. (2015). Using the RE-AIM framework to evaluate a community-based summer camp for children with obesity: a prospective feasibility study. BMC Obesity, 2 (21), 1-10.

CATCH (2014). CATCH PE: Resources for the Physical Educator. Available at http://catchinfo.org/wp-content/uploads/2014/10/Catch-PEnew.pdf. Accessed 14 March 2017.

CDC. (2012). Oklahoma State Nutrition, Physical Activity, and Obesity Profile. Available at http://www.cdc.gov/obesity/stateprograms/fundedstates/pdf/Oklahoma-StateProfile.pdf. Accessed 24 October 2016.

Clinks (2017). Using Control Group Approaches to Identify Impact. Available at http://www.clinks.org/sites/default/files/UsingControlGroupApproachesToIdentif yImpact. Accessed March 10, 2017.

Cooper C, Sarvey S, Collier D, Willson C, Green I, Pories ML, ..., Pories W. (2006). For comparison: experience with a children's obesity camp. Surgery for Obesity and Related Diseases, 2(6), 622-626.

Dimitriou, M., Michalopoulou, M., Gourgoulis, V., \& Aggelousis N. (2011). Participation in community-based sport skills learning programs, physical activity recommendations and health-related fitness for children in Greece. Sport Science Health, 6, 93-102.

Dudley, D. A., Cotton, W. G., \& Peralta, L.R. (2015), Teaching approaches and strategies that promote healthy eating in primary school children: a systematic review and meta-analysis. The International Journal of Behavioral Nutrition and Physical Activity, 12(28), 1-28.

Dzewaltowski, D. A., Rosenkranz, R. R., Geller, K. S., Coleman, K. J., Welk, G. J., Hastmann, T. J., Milliken, G. A. (2010). HOP'N after-school project: an obesity 
prevention randomized controlled trial. The International Journal of Behavioral Nutrition and Physical Activity, 7(90), 1-12.

Eisenmann, J.C., Gentile, D.A., Welk, G.J., Callahan, R., Strickland, S., \& Walsh, M. (2008). SWITCH: rationale, design, and implementation of a community, school, and family-based intervention to modify behaviors related to childhood obesity. BMC Public Health, 8(223), 1-10.

Farhat, A. E., Sharma, S., Abrams, S. H., Wong, W. W., \& Barlow, S. E. Kamp K'aana. (2016) a 2-Week Residential Weight Management Summer Camp, Shows LongTerm Improvement in Body Mass Index z Scores. Journal of Pediatric Gastroenterology and Nutrition, 62(3), 491-494.

Fryar, C. D., Gu, Q., \& Ogden, C. L. (2012). Anthropometric reference data for children and adults: United States, 2007-2010. National Center for Health Statistics. Vital Health Stat, 11(252), 22.

Gately, P. J., Cooke, C. B., Butterly, R. J., Mackreth, P., \& Carroll, S. (2000). The effects of a children's summer camp programme on weight loss, with a 10 month followup. International Journal of Obesity \& Related Metabolic Disorders, 24(11), $1445-1452$.

Gately, P. J., Cooke, C. B., Barth, J. H., Bewick, B. M., Radley, D., \& Hill, A. J. (2005). Children's residential weight-loss programs can work: a prospective cohort study of short-term outcomes for overweight and obese children. Pediatrics, 116(1), 7377.

Gentile, D. A., Welk, G., Eisenmann, J. C., Reimer, R. A., Walsh, D. A., Russell, D. W., ... Fritz, K. (2009). Evaluation of a multiple ecological level child obesity prevention program: Switch ${ }^{\circledR}$ what you Do, View, and Chew. BMC Medicine, 7 (49), 1-12.

George, G. L., Schneider, C., \& Kaiser, L. (2016). Healthy Lifestyle Fitness Camp: A Summer Approach to Prevent Obesity in Low-Income Youth. Journal Of Nutrition Education \& Behavior, 48(3), 208-212.

Hall, E., Chai, W., Koszewski, W., \& Albrecht, J. (2015). Development and validation of a social cognitive theory-based survey for elementary nutrition education program. The International Journal of Behavioral Nutrition and Physical Activity, 12(47), 1-12.

Higgins, J. A., LaSalle, A. L., Zhaoxing, P., Kasten, M. Y., Bing, K. N., Ridzon, S. E.c/, \& Witten, T. L. (2009). Validation of photographic food records in children: are pictures really worth a thousand words?. European Journal Of Clinical Nutrition, 63(8), 1025-1033. 
Jamelske, E., Bica, L.A., McCarty, D.J., Meinen, A., (2008). Preliminary Findings from an Evaluation of the USDA Fresh Fruit and Vegetable Program in Wisconsin Schools. Wisconsin Medical Journal, 107(5), 225-230.

Kelder, S., Hoelscher, D. M., Barroso, C. S., Walker, J. L., Cribb, Hu, P. S. (2005). The CATCH Kids Club: a pilot after-school study for improving elementary students' nutrition and physical activity. Public Health Nutrition, 8(2), 133-140.

Kuwait Nutrition Profile - Nutrition and Consumer Protection Division, FAO, 2006.

Larsen, K. T., Huang, T., Ried-Larsen, M., Andersen, L. B., Heidemann, M., \& Møller, N. C. (2016). A Multi-Component Day-Camp Weight-Loss Program Is Effective in Reducing BMI in Children after One Year: A Randomized Controlled Trial. PLoS ONE, 11(6), e0157182.

Ling J, King KM, Speck BJ, Kim S, \& Wu D. (2014). Preliminary assessment of a school-based healthy lifestyle intervention among rural elementary school children. Journal of School Health, 84(4), 247-255.

Magalhães, Elma Izze da Silva, Sant'Ana, Luciana Ferreira da Rocha, Priore, Silvia Eloiza, \& Franceschini, Sylvia do Carmo Castro. (2014). Perímetro da cintura, relação cintura/estatura e perímetro do pescoço como parâmetros na avaliação da obesidade central em crianças. Revista Paulista de Pediatria, 32(3), 273-281.

Moreno JP, Johnston CA, Woehler D. (2013). Changes in Weight Over the School Year and Summer Vacation: Results of a 5-Year Longitudinal Study. J Sch Health, 83(7), 473-477.

Neumark-Sztainer, D., Wall, M., Larson, N. I., Eisenberg, M. E., \& Loth, K. (2011). Dieting and disordered eating behaviors from adolescence to young adulthood: findings from a 10-year longitudinal study. Journal of American Dietetic Association, 111(7), 1004-1011.

Nicklaus, S., \& Remy, E. Early origins of overeating: tracking between early food habits and later eating patterns. Current Obesity Reports, 2(2), 179-184.

Qingya, T., Huijuan, R., Yexuan, T., Xiaofei, Z., Xiuhua, S., \& Wei, C. (2014). Effects of a summer program for weight management in obese children and adolescents in Shanghai. Asia Pacific Journal Of Clinical Nutrition, 23(3), 459-464.

Sigmund, E., El Ansari, W., \& Sigmundová, D. (2012). Does school-based physical activity decrease overweight and obesity in children aged 6-9 years? A two-year non-randomized longitudinal intervention study in the Czech Republic. BMC Public Health, 12(570), 1-12. 
Slusser, W. M., Sharif, M. Z., Erausquin, J. T., Kinsler, J. J., Collin, D., Prelip, M. L. (2013). Improving overweight among at-risk minority youth: results of a pilot intervention in after-school programs. Journal of Health Care for the Poor and Underserved, 24(2 Suppl), 12-24.

Smith DT, Bartee RT, Dorozynski CM, Carr LJ. (2009). Prevalence of overweight and influence of out-of-school seasonal periods on body mass index among American Indian schoolchildren. Prev Chronic Dis,6(1), A20.

Speroni, K., Tea, C., Earley, C., Niehoff, V., \& Atherton, M. (2008). Evaluation of a Pilot HospitalBased Community Program Implementing Fitness and Nutrition Education for Overweight Children. Journal for Specialists in Pediatric Nursing, 13(3), 144-153.

Stang, J., \& Story, M. (2005). Guidelines for Adolescent Nutrition Services. Available at http://www.epi.umn.edu/let/pubs/adol_book.shtm. Accessed 25 October 2016.

Tarro, L., Llauradó, E., Albaladejo, R., Moriña, D., Arija, V., Solà, R., Giralt, M. (2014). A primary-school-based study to reduce the prevalence of childhood obesity - the EdAl (Educació en Alimentació) study: a randomized controlled trial. Trials, 15(58).

Von Hippel PT, Powell B, Downey DB, Rowland NJ. (2007). The effect of school on overweight in childhood: gain in body mass index during the school year and during summer vacation. Am J Public Health, 97(4), 696-702.

Wang Y., Wu Y., Wilson R. F., Bleich S., Cheskin L., Weston C., ... Segal J. (2013). Childhood Obesity Prevention Programs: Comparative Effectiveness Review and Meta-Analysis. Rockville (MD): Agency for Healthcare Research and Quality (US); (Comparative Effectiveness Reviews, No. 115.)

Werner, D., Teufel, J., Holtgrave, P. L., Brown, S. L. (2012). Active generations: an intergenerational approach to preventing childhood obesity. The Journal of School Health, 82(8), 380-386.

WHO. (2016). Ending Childhood Obesity. Available at http://apps.who.int/iris/bitstream/10665/204176/1/9789241510066_eng.pdf?ua=1. Accessed 20 October, 2016.

WHO. (2017). Obesity and overweight. Available at http://www.who.int/mediacentre/factsheets/fs311/en/. Accessed 10 November 2017. 


\section{CHAPTER III: METHODOLOGY}

\section{Subject Recruitment}

An eight-week randomized control trial was conducted during summer 2017 (July - August) with intervention and comparison groups. Participating summer-camps where selected from the Mathllah Expo the largest annual summer-camps expo specialized in the development of child's skills in Kuwait. Summer-camps that are interested and eligible for this study were contacted. Two comparable summer camps in regard to the activities they offer, socioeconomic status, serving both male and female students, at the age between 6-10 years in Kuwait participated in the study. One camp was randomly assigned to the intervention group and the other to comparison group.

Convenient sampling was used to recruit participants attending the two summer camps who met the eligibility criteria. In order to participate in this study children had to be $6-10$ years old, attend the participating summer camps, willing to participate in the 8 weeks of intervention (from July 2nd to August 31st, 2017) and data collection pre-and post- intervention, willing and able to participate in physical activities, and had to provide parent consent and child assent. Children who didn't meet the inclusion criteria, suffered from a chronic disease, or had a physical or mental disability were excluded. All the required assessments took place at the summer camps the children were attending (week 0) one week before the intervention, and (week 9) 1 week post intervention.

Children attending the participating summer camps received a flyer about the study. Information included what the study was about, when it would be conducted, why, where, and by whom. It also included contact information so that they could contact the 
investigator. Written consent and assent forms were obtained from the parents and children to participate in the study. Approval was obtained from Institutional Review Board at Florida International University (FIU IRB number: IRB-17-0197). A demographic questionnaire was obtained from the parents and they were informed that all of the information would be kept confidential all the times.

From the intervention summer camp, 41 children participated in the preassessment and intervention. The intervention included nutrition education and physical activities two days a week for eight weeks. While the comparison group, 38 children participated in the pre-assessment and then they continued regular summer-camp activities without any kind of intervention for eight weeks. After the eight weeks, 39 children from intervention group and 38 children from the comparison groups received post intervention assessment.

\section{Sample}

A total of 89 participants were screened, 79 were eligible for the study based on the inclusion/exclusion criteria. Four in the intervention group, joining the camp for less than 2 months were excluded. Two from the comparison group, 2 from the intervention group had chronic diseases ( 1 diabetes and 1 heart disease), and 2 from the control group had diseases (1 diabetes and 1 G6PD) were excluded. Forty-one children from the intervention group and 38 from the comparison group participated in this study. Two participants from the intervention group were excluded due to attendance rate less than $80 \%$. Therefore, data from 79 participants were included in the final analysis of this study. 


\section{Intervention sessions}

Physical activity sessions: The physical activity sessions were conducted four days a week for 20 minutes per day. The sessions were focused on motivating the children to engage in moderate to vigorous physical activities (MVPA). The activities were developed based on $\mathrm{CATCH}$ physical education activity box which provides more than 300 age appropriate fun games and activities. These activities included: worm up, flexibility, muscle strength, endurance, aerobic games, fitness, and cool down (CATCH, 2014). All the activities that were suitable to be used regarding to the space and material available were placed in a draw box and each time one participant can draw an activity.

Nutrition Education sessions: The nutrition education sessions were conducted by the principle investigator 2 days a week for 40 minutes per day; the first 20 minutes were used for discussion and interaction about the topic of the week and the second 20 minutes for hands on activities related to the topic. The participants were divided into 2 groups based on their age ( 6 and 7 years old in one class, $8-10$ in another class). The nutrition education sessions provided information and activities emphasizing the importance of healthy eating based on the social cognitive theory. It is based on the idea that behavior change result from the dynamic interactions between individuals and their environments (Bandura, 1993).

These lessons are obtained from CATCH Kids Club nutrition curriculum and Myplate. The sessions were divided into themes, and delivered in the form of group learning games, individual practices, stories, discussions, skill building activities, and goal setting. The topics covered included: My plate, the food groups, sugary beverages vs water, screen time, physical activity. 


\section{Measures}

Socio-demographic questionnaire: After signing the consent forms, the parents were asked to fill out the sociodemographic questionnaire at baseline (week 0). The questionnaire included information related to sociodemographic variables such as: age, gender, income, number of siblings, and history of nutrition education classes taken by the child or the mother.

Modified Healthy Habits Survey (: HHS was used to measure children's knowledge, behavior and attitude about nutrition, screen time and physical activities pre(week 0) and post-intervention (week 9). It was used to assess whether the intervention increased the child's knowledge and improved attitude about nutrition and physical activities. This questionnaire measures eating behaviors, physical activity and screen time behaviors, nutrition and physical activity knowledge, food preferences, self-efficacy and intentions for healthy eating and physical activity outcomes. Behavior questions in the survey were scored from 1 to 4 or 1 to 5 , the higher the score the more positive the response is. For self-efficacy, items were scored from 1 to 3 representing low, medium, to high self-efficacy. For knowledge, 1 was given for a correct answer and 0 for incorrect answer (Hall et al., 2015). The questionnaire was modified to fit the Kuwaiti culture from types of foods and language. The survey was translated to Arabic the native language of the country and "ham" was replaced by "beef" since ham is not a food choice in Kuwait. HHS consisted of 40 questions and took around 20 minutes to be completed.

BMI percentile: The children's height and weight were measured using the same stadiometer for pre-intervention and post-intervention. The stadiometer was placed 
behind a partition in a hard-even floor. Children's weight was measured in light clothing without shoes. The children stood on the scale with their feet slightly apart and not touching anything. The weight was measured to the nearest $0.1 \mathrm{~kg}$. Height of the children was measured standing straight, head straight, and their back against the stadiometer without shoes and hair accessories that can affect the child's height, and the height was recorded to the nearest $0.1 \mathrm{~cm}$. BMI-for-age percentile was calculated by using WHO BMI AnthroPlus software (WHO, 2017b). BMI-for age percentile helped to assess if the intervention was effective in reducing the weight of the participants (Fryar, Gu, \& Ogden, 2012).

Waist-to-height ratio (WHtR): WHtR was used to assess central obesity in the children since it is a cost-effective way for measuring central obesity (Magalhães et al., 2014). The children's waist circumference was measured behind a partition using measuring tape at the uppermost lateral border of the hip crest. A cutoff point of 0.5 has been established to indicate central obesity if the child has a value greater than 0.5 (Fryar, et al., 2012).

\section{Statistical analysis.}

The independent variables were the nutrition education and physical activity classes attendnce. The dependent variables were the participants nutrition, physical activity, and screen time Knowledge and behavior, and participants WHtR and BMI percentile. The intervention group is the group of participants that received the nutrition education intervention for 8 weeks. The comparison group is the group that didn't receive any kind of intervention. 
For descriptive statistics, chi squared test for categorical variables and independent t-test for continues variables were used in the demographic characteristics. Chi square test was also used for the distributions of subjects' BMI category and central obesity, pre- and post-intervention in comparison and intervention groups. To study the effect of participating in the intervention, paired t-test and was used to determine changes in Nutritional Knowledge score and score of food intake, BMI percentile, and waist-toheight ratio before and after the intervention between intervention and comparison groups. McNemar's test was used to analyze pretest-posttest variables related to healthy and unhealthy food intake, changes in physical activity and screen time knowledge, time spent on physical activity and screen time between the intervention and comparison group. Multiple regression was used to see the effect of age and gender on participants BMI percentile difference (after-before). Boxplot was used to show BMI percentile difference before and after intervention. The significance level for outcomes was set on $p$ $<0.05$. The statistical analysis was done using SPSS 23.0. 


\section{CHAPTER IV: The effect of My Healthy Habits summer camp on improving the participant's nutrition knowledge and behavior}

\section{Introduction}

The prevalence of overweight and obesity has tripled since the 70s. It has reached 1.9 billion (39\%) of overweight adults, more than 650 million (13\%) of obese adults and over than 340 million (18\%) of overweight and obese children and adolescents aged 5-19 worldwide. (CDC, 2012). According to Obesity Rates by Country report in 2017 Middle East region is the second highest region for obesity after Oceania Islands, and Kuwait was ranked number 11 most obese country worldwide with $39.7 \%$ of Kuwaiti adults are obese, and $21.6 \%$ of children aged 6-18 years old are overweight and $30.5 \%$ are obese (Renew Bariatrics, 2017; Elkum et al., 2016). With this rapidly increasing prevalence of obesity, WHO considered childhood obesity to be a global epidemic (Wang, Wu, Wilson, Bleich, Cheskin, et al., 2013).

Based on the review of the scientific evidence, WHO developed recommendations to combat childhood obesity. These recommendations include: 1) Promote intake of healthy foods and reduce intake of unhealthy foods and sugarsweetened beverages, 2) Promote physical activity and reduce sedentary behaviors, 3) Provide a healthy school environment, and nutrition and physical activity education, and 4) Provide family-based weight management services for obese children (WHO, 2016). After-school, summer-camps, and child-care programs offer opportunities to deliver these recommendations in a convenient setting for the participants (Kelder, Hoelscher, Barroso, Walker, Cribb, et al., 2005). 
The literature showed that school based interventions can be successful in developing intervention programs related to children's nutrition knowledge or eating habits. Especially that children spent most of their day in the school (Jamelske, Bica, McCarty, Meinen, 2008; Ling, King, Speck, Kim, \& Wu, 2014). However, students tight schedule or the teacher lack of interest may interfere with providing the opportunity and enjoyment of nutrition education.

Therefore, targeting children during their free time such as in aftercare or school breaks is more convenient in increasing nutritional knowledge and modifying nutritional behavior. Knowledge, believes, and attitude about nutrition was seen in the increased consumption of fruits and vegetables, participating in preparation of heal thy snacks which increases the children opportunities to try healthy foods and increasing their selfefficacy by preparing their own healthy snacks, and increasing social support and motivating the children by seeing their peers are enjoying snack preparation (Werner, Teufel, Holtgrave, \& Brown, 2012).

Systematic review of six childhood obesity prevention programs that investigated the involvement of the parents for their children's behavior change. All of these studies showed positive significant outcomes in their children's BMI, diet and physical activities. However, childhood obesity prevention programs that involve the parents had more significant outcomes than childhood obesity prevention programs that does not involve the parents (Almarzooqi, \& Nagy, 2011). Also, summer-camp related intervention programs were seen to be affective for children aged 6 -12 years behavioral modification. suggesting that 8 weeks summer camps can be effective venues to change the children perception about healthy eating (Gately, Cooke, Butterly, Mackreth, \& Carroll, 2000). 
Although school intervention programs aimed to reduce obesity have been developed in the United States and Europe; no known programs exist in the Middle East including Kuwait. Furthermore, there are no known programs for after school or summer camps focused on obesity prevention in Kuwait. The literature provided strong evidence on the effectiveness of summer-camp interventions on creating a suitable environment to expose children to healthy lifestyle including healthy eating habits and physical activities (Burke, et al., 2015; Gately, Cooke, Butterly, Mackreth, \& Carroll, 2000; Larsen, et al., 2016; George, Schneider, \& Kaiser, 2016; Qingya, et al., 2014; Cooper, et al., 2006; and Gately, et al., 2005)

Since afterschool programs are not available in Kuwait, and the children have a lot of free time during summer break. Summer-camps provides the best opportunity to deliver this type of interventions with the aim of assessing the effectiveness of an eightweek intervention at a summer camp to prevent overweight and obesity, and promote healthy eating habits and physical activity among children in Kuwait. This paper examines the nutrition knowledge and behavior outcome.

\section{Methods}

\section{Subject Recruitment}

An eight weeks randomized control trial was conducted during summer 2017 (July - August) with intervention and comparison groups. Participating summer-camps where selected from Mathllah Expo the largest annual summer-camps expo specialized in the development of child's skills in Kuwait. Summer-camps that are interested and 
eligible for this study where contacted. Two comparable summer camps in regard to the activities they offer, socioeconomic status, serving both genders, at the age between 6-10 years in Kuwait participated in the study. One camp was randomly assigned to intervention group and the other to comparison group. Convenient sampling was used to recruit participants attending the two summer camps who wish to participate and meet the eligibility criteria. Pre-test/post-test screening was done for the participants in the intervention and comparison groups.

In order to participate in this study children had to be $6-10$ years old, attending the participating summer camps, willing to participate in the 8 weeks of intervention (from July 2nd to August 31st, 2017) and data collection pre-and post- intervention, willing and able to participate in physical activities, and provide parent consent and child assent. Children who don't meet the inclusion criteria, inability to participate in physical activity, suffering from a chronic disease, physical or mental disability were excluded. All the required assessments took place in the same summer camps the children were attending (week 0) one week before the intervention, and (week 9) 1 week post intervention

Children attending the participating summer camps received a flyer about the study. Information included what the study was about, when it would be conducted, why, where, and by whom. It also included contact information if they are interested in participating they can contact the investigator. Written consent and assent forms were obtained from the parents and children to participate in the study. Approval was obtained from Institutional Review Board at Florida International University (FIU IRB number: 
IRB-17-0197). Demographic questionnaire was obtained from the parents and they were informed that all of the information would be kept confidential all the times.

From the intervention summer camp 41 children participated in the preassessment followed by the intervention including nutrition education and physical activities two days a week for eight weeks. While the comparison group, 38 children participated in the pre-assessment and then they continued regular summer-camp activities without any kind of intervention for eight weeks. After the eight weeks, 39 children from intervention group and 38 children from the comparison groups received post intervention assessment.

A total of 89 participants were screened, 79 were eligible for the study based on the inclusion/exclusion criteria. Four in the intervention group, joining the camp for less than 2 months were excluded. Two from the comparison group, 2 from the intervention group had chronic diseases ( 1 diabetes and 1 heart disease), and 2 from the control group had diseases (1 diabetes and 1 G6PD) were excluded. Forty-one children from the intervention group and 38 from the comparison group participated in this study. Two participants from the intervention group were excluded due to attendance rate less than $80 \%$. Therefore, data from 79 participants were included in the final analysis of this study.

\section{Intervention sessions}

Physical activity sessions: The physical activity sessions were conducted four days a week for 20 minutes per day. the sessions were focused on motivating the children to engage in moderate to vigorous physical activities (MVPA). The activities were 
developed based on CATCH physical education activity box which provides more than 300 age appropriate fun games and activities. These activities included: worm up, flexibility, muscle strength, endurance, aerobic games, fitness, and cool down (CATCH, 2014).

Nutrition Education sessions: The nutrition education sessions were conducted by the principle investigator 2 days a week for 40 minutes per day; the first 20 minutes for discussion and interaction about the topic of the week and the second 20 minutes for hands on activities related to the topic. The participants were devided into 2 groups based on their age (6 and 7 years old in one class, $8-10$ in another class). The nutrition education sessions provided information and activities emphasizing the importance of healthy eating based on the social cognitive theory. It is based on the idea that behavior change result from the dynamic interactions between individuals and their environments (Bandura, 1993). These lessons are obtained from CATCH Kids Club nutrition curriculum. The sessions were divided into themes, and delivered in the form of group learning games, individual practices, stories, discussions, skill building activities, and goal setting. The topics covered included: My plate, the food groups, sugary beverages vs water, screen time, physical activity.

\section{Measures}

Socio-demographic questionnaire: After signing the consent forms, the parents were asked to fill out the sociodemographic questionnaire at baseline (week 0). The questionnaire included information related to sociodemographic variables such as: age, 
gender, income, number of siblings, the child's rank in the family, and nutrition background related to the child and the mother.

Modified Healthy Habits Survey (HHS): HHS was used to measure children's knowledge, behavior and attitude about nutrition, screen time and physical activities pre(week 0) and post-intervention (week 9). It was used to assess whether the intervention increased the child's knowledge and improved attitude about nutrition and physical activities. This questionnaire measures eating behaviors, physical activity and screen time behaviors, nutrition and physical activity knowledge, food preferences, self-efficacy and intentions for healthy eating and physical activity outcomes (Hall et al., 2015). The questionnaire was modified to fit the Kuwaiti culture from types of foods and language. The survey was translated to Arabic the native language of the country and "ham" was replaced by "beef" since ham is not a food choice in Kuwait. HHS consisted of 40 questions and took around 20 minutes to be completed.

\section{Statistical analysis}

The independent variable was the nutrition education classes. The dependent variables were the participants nutrition Knowledge and behavior. The intervention group is the group of participants that received the nutrition education intervention for 8 weeks. The comparison group is the group that didn't receive any kind of intervention.

For descriptive statistics, chi squared test for categorical variables and independent t-test for continues variables were used in the demographic characteristics. To study the effect of participating in the intervention, paired t-test and was used to 
determine changes in Nutritional Knowledge score and score of healthy and unhealthy food intake before and after the intervention between intervention and comparison groups. McNemar's test was used to analyze changes in participants eating habits related to healthy and unhealthy food intake from baseline to post-intervention between the intervention and comparison group. The significance level for outcomes was set on $p$ $<0.05$. The statistical analysis was done using SPSS 23.0.

\section{Results}

\section{Baseline sociodemographic characteristics}

Baseline sociodemographic characteristics are summarized in table 1 for children and in table 2 for the mothers. There was no significant difference between the intervention and comparison groups in regard to children's or mother's sociodemographic characteristics. The only difference is that more mothers in the comparison group were overweight $(52.6 \%)$, compared to $25.6 \%$ of overweight mothers in the intervention group, $(p=0.008)$.

\section{Nutrition knowledge}

Nutrition knowledge score can be seen in (Table 3). There was a significant increase in the intervention group's nutrition knowledge score. It increased from $4.31 \pm 1.66$ at baseline to $10.46 \pm 1.17$ post-intervention for the intervention group $(\mathrm{P}<0.001)$, while there was no significant change in the comparison group; $5.61 \pm 2.22$ baseline and 5.95 1.94 post-intervention $(\mathrm{P}=0.25)$. 


\section{Nutrition behavior}

For eating behavior related to healthy food (table 3), there was a significant increase in the number of servings of healthy foods in the intervention group but not in the comparison group. Table 4 shows some of the questions related to healthy eating behaviors. There was significant increase in dairy, fruits, vegetables, whole grains, and protein consumption in the intervention group $(p=0.013, p=0.007,<0.001, p=0.002$, and $p=0.012$, respectively), but not significant in the control group $(p=0.607, p=0.219$, $p=0.727, p=1.00$, and $p=0.118$, respectively).

For eating behavior related to unhealthy food (table 3 ) there was a significant decrease in the total score of number of servings of unhealthy foods in the intervention group but not in the comparison group ( $p<0.001, p=0.506$, respectively). However, table 4 shows that there was no significant decrease in the number of servings of unhealthy foods in the intervention group nor in the comparison group for the number of serving of french-fries and chips, fruit flavored drinks or soft drinks. The only significant decrease in the unhealthy food intake was seen in the number of servings of sweets and candies in the intervention group. 14 participants in the intervention group decreased their consumption of sweets and candies to 1 time or less per day $(\mathrm{P}=0.001)$ while it was not significant in the control group $(\mathrm{P}=0.754)$.

\footnotetext{
Attendance

Average attendance rate was $91 \%$. The highest attendance was $100 \%$ of the intervention sessions and the lowest was $63 \%$. Only participants with attendance rate of $80 \%$ or higher were included in the analysis.
} 


\section{Discussion}

This study showed that children in Kuwait were lacking nutrition education as seen in low nutrition knowledge score at baseline and no previous nutrition education classes received by all of the participating children in both intervention and comparison groups. Teaching children the health benefits and nutritional values or the detriments of consuming unhealthy food is critical as it will help them know their choices or how to have a healthy meal.

This intervention was successful in increasing nutrition knowledge of children aged 6-10 years old by providing nutrition education sessions following CATCH Kids Club curriculum 2 times per week for 8 weeks. It showed to be successful in increasing the consumption of healthy food choices including fruits, vegetables, dairy, wholegrains, and lean proteins. It resulted in significant decrease in sweets and candies in the intervention group but not in other kinds of unhealthy food such as fries, and sugary drinks. However, the participants are already having low intake of these unhealthy foods.

Similar results were seen in the literature. Werner, et al. (2012) conducted a 10 lessons nutrition education and physical activity intervention following $\mathrm{CATCH}$ curriculum in summer camps "Active Generation" for children in $3^{\text {rd }}$ to $5^{\text {th }}$ grade. A significant increase in participants' fruits and vegetables consumption were demonstrated from pretest-posttest self-reported Active Generation validated survey. Seal and Seal (2011) aimed to increase participants knowledge on healthy foods, physical activities, and eating behavior. A self-reported survey was administrated on 18 children who 
participated in 10 days summer camp. The results of paired t-test analysis showed significant increase in children's knowledge and behavior related to healthy foods.

Most interventions are school based and only few interventions were conducted in summer camps were children had free time. No studies have been done in Kuwait as a nutrition education intervention. The groups were randomly assigned to intervention or comparison groups, and there was no significant difference between the two groups in regard to sociodemographic status. Also, we had low dropout rate by only two participants from the intervention group due to attending less than $80 \%$ of the classes.

Study limitation includes, desired sample size of 140 participants was not met, and only 79 participated due to long follow-up period and people in Kuwait tend to travel during summer break. There was a significant difference in the mother's BMI. The comparison group have significantly more overweight mothers than the intervention group which had more normal weight mothers, and that might have affected the comparability of the results. This study also is lacking long term follow-up to observe if the results were sustainable for the long-term.

In conclusion, the purpose of this study was to assess the effectiveness of an eight weeks intervention at "My Healthy Habits" summer camp on improving the participant's nutrition knowledge and behavior. The results of this study showed that following Catch Kids Club curriculum in My Healthy Habits summer camp for eight weeks was affective in improving nutritional knowledge, behavior, and promoting healthy eating habits for children aged 6-10 years in Kuwait during summer break. which in the long run can help preventing obesity and its related diseases (seal and seal, 2011). Long-term follow-up is recommended to check the sustainability of these results. 
Table 1. Children's Baseline demographic characteristics by treatment Group $(\mathrm{N}=77)$

\begin{tabular}{|c|l|l|l|}
\hline Characteristics & Comparison G & Intervention Grod & P-Value \\
\cline { 2 - 3 } & $\mathbf{n = 3 8}$ & $\mathbf{n = 3 9}$ & \\
\hline Age in years & $7.05 \pm 1.4$ & $7.41 \pm 1.46$ & 0.357 \\
\hline Nationality & & & 0.141 \\
\hline Kuwaiti & $94.7(36)$ & $89.7(35)$ & \\
\hline Other & $5.3(2)$ & $10.3(4)$ & \\
\hline Gender & & & 0.721 \\
\hline Male & $42.1(16)$ & $46.2(18)$ & \\
\hline Female & $57.9(22)$ & $53.8(21)$ & \\
\hline Order in the family & $2 \pm 1$ & $2 \pm 1$ & 0.924 \\
\hline Nutrition Education & & & \\
\hline No & $100(38)$ & $100(39)$ & \\
\hline Yes & $0(0)$ & $0(0)$ & \\
\hline
\end{tabular}

Continuous variable (age) are is presented as mean \pm SD and categorical variables as percentage (n). Level of significance set at $P<0.05$.

Abbreviations: $\mathrm{SD}=$ Standard Deviation

Table 2. Mothers' baseline demographic characteristics by treatment Group $(\mathrm{N}=77)$

\begin{tabular}{|l|l|l|l|}
\hline \multirow{2}{*}{ Characteristic } & Comparison G & Intervention Grou & P-Value \\
\cline { 2 - 3 } & $\mathbf{n = 3 8}$ & $\mathbf{n = 3 9}$ & \\
\hline Age in years & $35.58 \pm 4.89$ & $34.44 \pm 4.19$ & 0.448 \\
\hline Nationality & & & 0.052 \\
\hline Kuwaiti & $97.4(37)$ & $84.6(33)$ & \\
\hline Other & $2.6(1)$ & $15.4(6)$ & \\
\hline
\end{tabular}




\begin{tabular}{|l|l|l|l|}
\hline Marital status & & & 0.299 \\
\hline Married & $86.6(33)$ & $94.9(37)$ & \\
\hline Divorced & $7.9(3)$ & $5.1(2)$ & \\
\hline Number of kids) & $3 \pm 1$ & $3 \pm 1$ & 0.823 \\
\hline BMI & & & $0.008^{*}$ \\
\hline Underweight & $0(0)$ & $5.1(2)$ & \\
\hline Normal & $26.3(10)$ & $59(23)$ & \\
\hline Overweight & $52.6(20)$ & $25.6(10)$ & \\
\hline Obese & $21.1(8)$ & $10.3(4)$ & \\
\hline Education level & & & 0.511 \\
\hline High school or below & $10.5(4)$ & $5.1(2)$ & \\
\hline 2 years diploma & $26.3(10)$ & $23.1(9)$ & \\
\hline Bachelor degree & $55.3(21)$ & $53.8(21)$ & \\
\hline Graduate level & $7.9(3)$ & $17.9(7)$ & \\
\hline Monthly household income & & & 0.057 \\
\hline$<2000$ KD & $15.8(6)$ & $2.6(1)$ & \\
\hline $2000-3000$ KD & $47.4(18)$ & $69.2(27)$ & \\
\hline$>3000$ KD & $36.8(14)$ & $28.2(11)$ & \\
\hline Working status & & & 0.689 \\
\hline House wife & $31.6(12)$ & $35.9(14)$ & \\
\hline working & $68.4(38)$ & $64.1(25)$ & \\
\hline Nutrition Education & & & 0.094 \\
\hline No & $78.9(30)$ & $92.3(36)$ & \\
\hline Yes & $21.1(8)$ & $7.7(3)$ & \\
\hline Con & & \\
\hline
\end{tabular}

Continuous variable (age) is presented as mean $\pm \mathrm{SD}$ and categorical variables as percentage (n). * Represents significant differences. Level of significance set at $P<0.05$. Abbreviations: $\mathrm{SD}=$ Standard Deviation 
Table 3. Participants nutritional knowledge score at baseline and post-intervention

\begin{tabular}{|l|rrr|rrr|}
\hline & \multicolumn{3}{|c|}{ Comparison Group n $\mathbf{3 8}$} & \multicolumn{3}{|c|}{ Intervention Group n=39 } \\
\cline { 2 - 7 } & Baseline & Post Interve & P-Va & Baseline & Post Intervel & P-Val \\
\hline Nutritional knowledge & $5.61 \pm 2.2$ & $5.95 \pm 1.9$ & 0.2 & $4.31 \pm 1.6 t$ & $10.46 \pm 1.1$ & $<0.001 *$ \\
\hline Healthy food intake score & $10.29 \pm 1.7$ & $10.11 \pm 1.6$ & 0.5 & $9.97 \pm 2.6$ & $13.74 \pm 2.1$ & $<0.00$ \\
\hline & $13.5 \pm 1.9$ & $13.37 \pm 1.5$ & 0.5 & $12.79 \pm 1.8$ & $14.54 \pm 1.5$ & $<0.00$ \\
\hline
\end{tabular}

Paired t-test was used. Data represented by mean \pm SD

* Represents significant differences. Level of significance set at $P<0.05$. 
Table 4. Participants nutritional behavior change between baseline to post-intervention

\begin{tabular}{|c|c|c|c|c|c|c|}
\hline \multirow{3}{*}{$\begin{array}{l}\text { Yesterday, how many times did you } \\
\text { eat/drink ... } \\
\text { Baseline }\end{array}$} & \multirow{2}{*}{\multicolumn{3}{|c|}{\begin{tabular}{|c|} 
Comparison Group \\
$\mathbf{n}=\mathbf{3 9}$ \\
Post intervention
\end{tabular}}} & \multirow{2}{*}{\multicolumn{3}{|c|}{$\begin{array}{l}\text { Intervention Group } \mathbf{n}=\mathbf{3 8} \\
\text { Post intervention }\end{array}$}} \\
\hline & & & & & & \\
\hline & 1 time or & 2 times or & P-value & 1 time $\mathrm{o}$ & $\begin{array}{l}2 \text { time: } \\
\text { mor }\end{array}$ & P-value \\
\hline dairy, such as milk, yogurt, or cheese? & & & 0.6 & & & 0.013 \\
\hline 1 time or less & 17 & 6 & & 4 & 12 & \\
\hline 2 or more times & 9 & 6 & & 2 & 21 & \\
\hline $\begin{array}{l}\text { fresh, frozen, dried or canned fruit? (Do not c } \\
\text { fruit juice) }\end{array}$ & & & 0.2 & & & $0.00^{-}$ \\
\hline 1 time or less & 24 & 1 & & 17 & 1: & \\
\hline 2 or more times & 5 & 8 & & 2 & 7 & \\
\hline $\begin{array}{l}\text { fresh, frozen, or canned vegetables? (Do not co } \\
\text { French fries or potato chips) }\end{array}$ & & & 0.7 & & & $<0.00$ \\
\hline 1 time or less & 27 & 3 & & 16 & $1<$ & \\
\hline 2 or more times & 5 & 3 & & 0 & 9 & \\
\hline $\begin{array}{l}\text { whole grains, such as whole grain bread, whole } \\
\text { grain tortillas (not corn or white flour tortillas } \\
\text { whole grain pasta, or whole grain crackers? }\end{array}$ & & & 1.0 & & & 0.002 \\
\hline 1 time or less & 37 & 0 & & 20 & 1: & \\
\hline 2 or more times & 1 & 0 & & 1 & 5 & \\
\hline
\end{tabular}




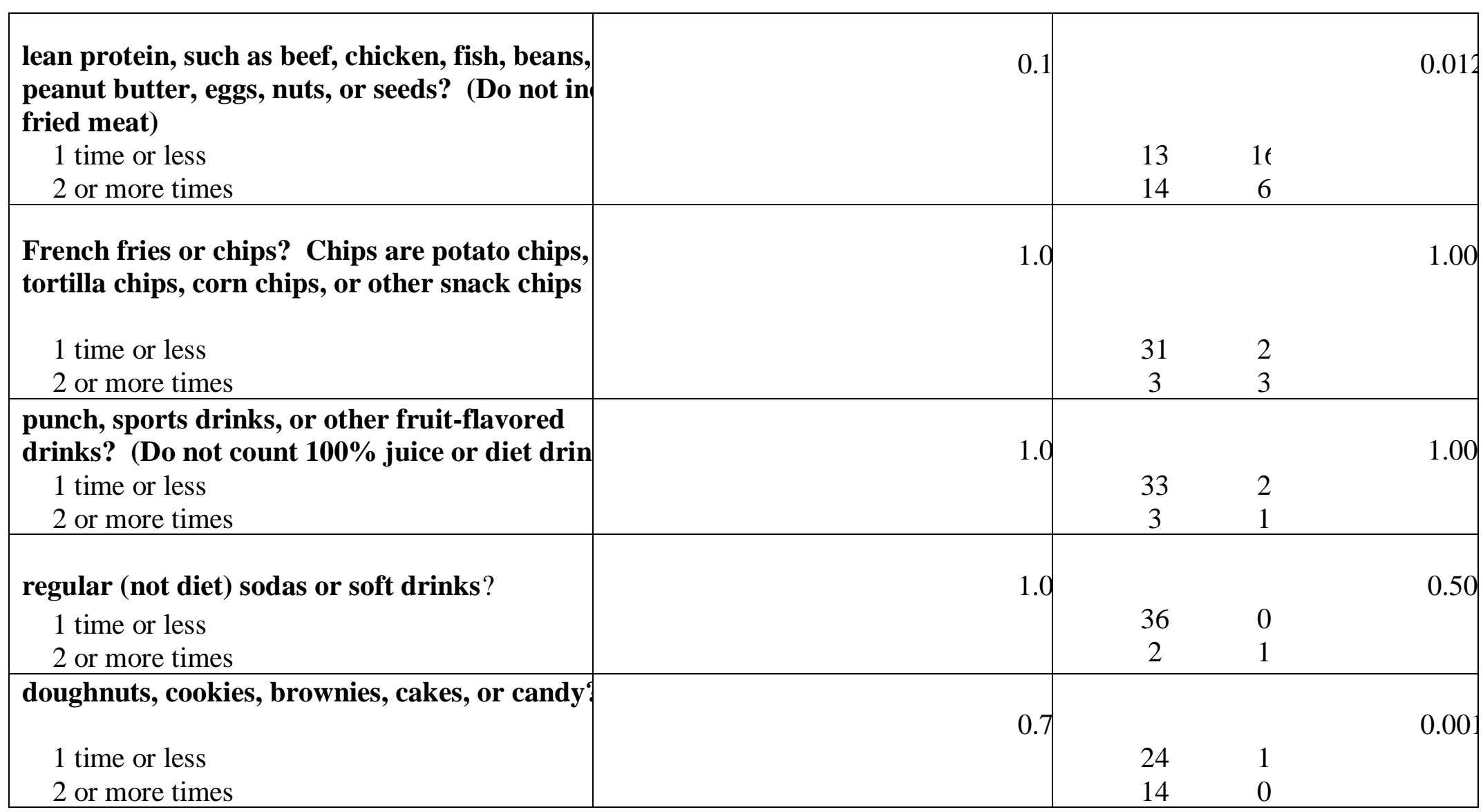

McNemar's test was used. Data represented by $n$

* Represents significant differences. Level of significance set at $P<0.05$. 


\section{References}

Almarzooqi, M. A., \& Nagy, M. C. (2011). Childhood Obesity Intervention Programs: A Systematic Review. Life Science Journal, 8(4), 45-60.

Bandura, A. (1993). Social foundations of thought and action: A social cognitive theory. Englewood Cliffs, NJ: Prentice-Hall.

Burke, S. M., Shapiro, S., Petrella, R. J., Irwin, J. D., Jackman, M., Pearson, E. S., ... Shoemaker, J. K. (2015). Using the RE-AIM framework to evaluate a community-based summer camp for children with obesity: a prospective feasibility study. BMC Obesity, 2 (21), 1-10.

CDC. (2012). Oklahoma State Nutrition, Physical Activity, and Obesity Profile. Available at http://www.cdc.gov/obesity/stateprograms/fundedstates/pdf/Oklahoma-StateProfile.pdf. Accessed 24 October 2016.

Cooper C, Sarvey S, Collier D, Willson C, Green I, Pories ML, ..., Pories W. (2006). For comparison: experience with a children's obesity camp. Surgery for Obesity and Related Diseases, 2(6), 622-626.

Elkum, N., Al-Arouj, M., Sharifi, M., Shaltout, A., and Bennakhi, A. (2016) Prevalence of childhood obesity in the state of Kuwait. Pediatric Obesity, 11: e30-e34.

Gately, P. J., Cooke, C. B., Butterly, R. J., Mackreth, P., \& Carroll, S. (2000). The effects of a children's summer camp programme on weight loss, with a 10 month followup. International Journal of Obesity \& Related Metabolic Disorders, 24(11), 1445-1452.

Gately, P. J., Cooke, C. B., Barth, J. H., Bewick, B. M., Radley, D., \& Hill, A. J. (2005). Children's residential weight-loss programs can work: a prospective cohort study of short-term outcomes for overweight and obese children. Pediatrics, 116(1), 7377.

George, G. L., Schneider, C., \& Kaiser, L. (2016). Healthy Lifestyle Fitness Camp: A Summer Approach to Prevent Obesity in Low-Income Youth. Journal Of Nutrition Education \& Behavior, 48(3), 208-212.

Hall, E., Chai, W., Koszewski, W., \& Albrecht, J. (2015). Development and validation of a social cognitive theory-based survey for elementary nutrition education program. The International Journal of Behavioral Nutrition and Physical Activity, 12(47), 1-12. 
Jamelske, E., Bica, L.A., McCarty, D.J., Meinen, A., (2008). Preliminary Findings from an Evaluation of the USDA Fresh Fruit and Vegetable Program in Wisconsin Schools. Wisconsin Medical Journal, 107(5), 225-230.

Kelder, S., Hoelscher, D. M., Barroso, C. S., Walker, J. L., Cribb, Hu, P. S. (2005). The CATCH Kids Club: a pilot after-school study for improving elementary students' nutrition and physical activity. Public Health Nutrition, 8(2), 133-140.

Larsen, K. T., Huang, T., Ried-Larsen, M., Andersen, L. B., Heidemann, M., \& Møller, N. C. (2016). A Multi-Component Day-Camp Weight-Loss Program Is Effective in Reducing BMI in Children after One Year: A Randomized Controlled Trial. PLOS ONE, 11(6), e0157182.

Ling J, King KM, Speck BJ, Kim S, \& Wu D. (2014). Preliminary assessment of a school-based healthy lifestyle intervention among rural elementary school children. Journal of School Health, 84(4), 247-255.

Qingya, T., Huijuan, R., Yexuan, T., Xiaofei, Z., Xiuhua, S., \& Wei, C. (2014). Effects of a summer program for weight management in obese children and adolescents in Shanghai. Asia Pacific Journal Of Clinical Nutrition, 23(3), 459-464.

Re:new Bariatrics. (2017). REPORT: OBESITY RATES BY COUNTRY - 2017. Available at https://renewbariatrics.com/obesity-rank-by-countries/. Accessed 10 November 2017.

Seal, N. and Seal, J. (2011), Developing healthy childhood behaviour: Outcomes of a summer camp experience. International Journal of Nursing Practice, 17: 428-434.

Wang Y., Wu Y., Wilson R. F., Bleich S., Cheskin L., Weston C., ... Segal J. (2013). Childhood Obesity Prevention Programs: Comparative Effectiveness Review and Meta-Analysis. Rockville (MD): Agency for Healthcare Research and Quality (US); (Comparative Effectiveness Reviews, No. 115.)

Werner, D., Teufel, J., Holtgrave, P. L., Brown, S. L. (2012). Active generations: an intergenerational approach to preventing childhood obesity. The Journal of School Health, 82(8), 380-386.

WHO. (2016). Ending Childhood Obesity. Available at http://apps.who.int/iris/bitstream/10665/204176/1/9789241510066_eng.pdf?ua=1. Accessed 20 October, 2016.

WHO. (2017). Obesity and overweight. Available at http://www.who.int/mediacentre/factsheets/fs311/en/. Accessed 10 November 2017. 


\section{CHAPTER V: The effect of "My Healthy Habits summer camp" on improving the participant's physical activity and screen time}

\section{Introduction}

Obesity is the energy imbalance caused by increased consumption of energy dense foods and decreased physical activity. For adults, obesity is defined by having Body mass index (BMI) equal or greater than 30 . For children obesity is age and sex specific and is defined using BMI growth charts since they are growing (CDC, 2016). During the last decade, there is 1.9 billion (39\%) of overweight adults, more than 650 million (13\%) of obese adults and over than 340 million (18\%) of overweight and obese children and adolescents aged 5-19 worldwide. (CDC, 2012). The prevalence of obesity has increased mainly due to technological developments. As a result, sedentary lifestyles increased which has strong link to environmental changes, commercial application, food availability, education, and changes in lifestyle (WHO, 2017).

Childhood obesity health consequences does not only affect their health during childhood but also has long-term consequences. The consequences of obesity include increased risk of metabolic syndrome, cardiovascular diseases, type 2 diabetes, nonalcoholic fatty liver disease, sleep apnea, orthopedic complications, and increased risks of cancer (Kelsey, Zaepfel, Bjornstad, \& Nadeau, 2014). These obesity related consequences can start early in life or develop later as they grow up. Also, obesity in childhood increase the likelihood of obesity in adulthood. Therefore, early intervention to prevent childhood obesity is very important.

Research has shown that Involving children in regular physical activities can be successful in preventing childhood obesity or even reducing overweight and obesity 
among elementary school aged children. Exercise also shown to be effective in increasing the children's moderate-to-vigorous physical activity in their free time and during the weekends (Sigmund, El Ansari, \& Sigmundová, 2012; Speroni, Tea, Earley, Niehoff, \& Atherton, 2008; Dzewaltowski, Rosenkranz, Geller, Coleman, Welk, et al. 2010). Published research indicates reduced body mass index and waist circumference, resulting from increased physical activity and reduced screen time (Robinson et al., 2003). When children participate in physical activity classes in their free time will also be reducing their free time available for screen viewing, thereby preventing weight gain among these children s (Robinson et al., 2003).

The US department of Health and Human Services recommends that children aged 6-17 years old engage in moderate to vigorous physical activity at least 60 minutes per day (US Department of Health and Human Services, 2008). Unfortunately, the majority of Kuwaiti children do not meet these requirements for physical activities instead they spend most of their time in sedentary activities and screen viewing (Allafi, A., et al., 2014).

Interventions are needed to increase physical activity among children and reduce their screen time to less than 2 hours per day. One way to do so is to make the physical activities interactive and enjoyable especially if it is going to be in a summer camp where kids want to enjoy their summer holidays. The aim of this study was to assess the effectiveness of an eight-week intervention at a summer camp on improving the participant's physical activity level and screen time. 


\section{Methods}

\section{Subject Recruitment}

Eight weeks randomized control trial was conducted during summer 2017 (July August) with intervention and comparison groups. Participating summer-camps were selected from Mathllah Expo the largest annual summer-camps expo specialized in the development of child's skills in Kuwait. Summer-camps that were interested and eligible for this study were contacted. Two comparable summer camps in regard to the activities they offer, socioeconomic status, serving both genders, at the age between 6-10 years old in Kuwait selected to participate in the study. One camp was randomly assigned to intervention group and the other to comparison group. Convenient sampling was used to recruit participants attending the two summer camps who wish to participate and meet the eligibility criteria. Pre-test/post-test screening was done for the participants in the intervention and comparison groups.

A total of 89 participants were screened, 79 were qualified for the study based on the inclusion/exclusion criteria; 4 in the intervention group are joining the camp for less than 2 months and 2 from the comparison group, 2 from the intervention group with chronic diseases ( 1 diabetes and 1 heart disease), and 2 from the control group diseases (1 diabetes and 1 G6PD), 41 from the intervention group and 38 from the comparis on group participated in this study. 2 participants in the intervention group due to attendance rate less than $80 \%$. Therefore, data from 79 participants were included in the analysis of this intervention.

In order for the participant to be part of this study were $6-10$ years old, attending the participating summer camps, willing to participate in an 8 week of intervention (from 
July 2nd to August 31st, 2017) and data collection pre-and post- intervention, willing and able to participate in physical activities, and provided parent consent and child assent to participate. Children who did not meet the inclusion criteria, inability to participate in physical activity, suffering from a chronic disease, physical or mental disability were excluded. The required assessments took place at the same summer camps the children were attending (week 0) one week before the intervention, and (week 9) 1 week post intervention.

Children attending the participating summer camps received a flyer about the study. Information included what the study was about, when it would be conducted, why, where, and by whom. It also included contact information if they are interested in participating they could contact the investigator. Written consent and assent forms were given to parents and children reviews and signatures in order to participate in the study. Approval was obtained from Institutional Review Board at Florida International University (FIU IRB number: IRB-17-0197). Demographic questionnaire was obtained from the parents and they were informed that all of the information is confidential all the times.

From the intervention summer camp, 41 children participated in the preassessment followed by eight weeks of intervention including nutrition education and physical activities two days a week for eight weeks. While the comparison group, 38 children participated in the pre-assessment and they continued regular summer-camp activities without any kind of intervention for eight weeks. After the eight weeks, 39 children from intervention group and 38 children from the comparison groups received post intervention assessment. 


\section{Interventions}

Physical activity: The physical activity sessions were conducted four days a week for 20 minutes per day. Sessions focused on motivating children to engage in moderate to vigorous physical activities (MVPA). The activities were developed based on CATCH physical education activity box which provides more than 300 age appropriate fun games and activities. These activities included: worm up, flexibility, muscle strength, endurance, aerobic games, fitness, and cool down exercises (CATCH, 2014).

\section{Measures}

Socio-demographic questionnaire: After signing the consent forms, parents were asked to fill out the sociodemographic questionnaire at baseline (week 0). The age, gender, income, number of siblings, the child's rank in the family, and nutrition background learned from nutrition education classes for the child and the mother.

Modified Healthy Habits Survey (HHS): HHS was used to measure children's knowledge, behavior and attitude about nutrition, screen time and physical activities pre(week 0) and post-intervention (week 9). It was used to assess whether the intervention increased the child's knowledge and attitude about nutrition and physical activities. This questionnaire measured eating behaviors, physical activity and screen time behaviors, nutrition and physical activity knowledge, food preferences, self-efficacy and intentions for healthy eating and physical activity outcomes (Hall et al., 2015). The questionnaire was modified to fit the Kuwaiti culture from types of foods and language. The survey was translated to Arabic the native language of the country and "ham" was replaced with 
"beef" since ham is not a food choice in Kuwait. HHS consisted of 40 questions and took around 20 minutes to be answered.

\section{Statistical analysis}

The independent variables of the study were screen time and physical activity classes and physical activity sessions. The dependent variables were participants' physical activity and screen time knowledge and behavior. The intervention participants received the educational classes and physical activity sessions for 8 weeks. The comparison group received no intervention.

Chi squared test for categorical variables and independent t-test for continues variables were used for demographic characteristics. McNemar's test was used to analyze pretest-posttest variables related to changes in physical activity and screen time knowledge, time spent on physical activity or screen time between the intervention and comparison group. The significance level for outcomes was set on $(p<0.05)$. the statistical analysis was done using SPSS 23.0.

\section{Results}

\section{Baseline sociodemographic characteristics}

Baseline sociodemographic characteristics are summarized in table 1 for the children and in table 2 for the mothers. There was no significant difference between the two groups in regard to age $(7.05 \pm 1.4$ years for comparison group and $7.41 \pm 1.46$ years for intervention group, $p=0.367)$, Kuwaiti nationality (94.7\% vs. $89.7 \%$, for comparison and intervention groups respectively, $p=0.141)$ gender $(p=0.721)$, or the order of the 
child in the family $2 \pm 1 p=0.924)$. It also showed that none of the children received any kind of nutrition education before.

There were no significant differences in the sociodemographic variables between the intervention and comparison groups. More mothers in the comparison group were overweight $(52.6 \%)$, while $25.6 \%$ of overweight mothers in the intervention group, $(p=0.008)$. The mean age of the mothers was $35.6 \pm 4.9$ years $(p=0.448)$, majority of the mothers were Kuwaiti (97.4\% vs. $84.6 \%$ for comparison and intervention groups respectively, $p=0.052$ ), $86.6 \%$ and $94.9 \%$ of the mothers were married for comparison and intervention groups respectively $(p=0.299)$. The mean number of children was $3 \pm 1$ for both groups ( $p=0.823$ ). Majority of the mothers had bachelor's degree $55.3 \%$ for comparison group and $53.8 \%$ for the intervention group $(p=0.511)$. Most of the families had middle income (2000-3000 KD/month, $p=0.057)$. Sixty-Eight-point four percent of the mothers in the comparison group and $64.1 \%$ in the intervention group were working $(p=0.689)$ and the majority did not receive nutrition education classes before $(78.9 \%$ and $92.3 \%$ respectively, $p=0.094)$.

\section{Physical activity and screen time knowledge}

Physical activity and screen time knowledge are presented in table 3 . It shows that there was a significant increase in the intervention group in both physical activity and screen time knowledge $(p<0.001)$. In the intervention group when participants were asked "How many minutes of physical activity do you think you should get each day to be healthy?", 25 participants who answered incorrectly at baseline, answered correctly post intervention $(p<0.001)$. The comparison group on the other hand didn't show any 
significant increase in screen time or physical activity knowledge ( $p=0.125, p=0.687$, respectively). More questions are presented in table 3 regarding physical activities and screen time knowledge.

\section{Physical activity and screen time behavior}

There was a significant decrease in time spent on screen viewing in the intervention group from more than two hours per day to the recommended time of screen viewing of two hours or less $(p<0.001)$.

There was a significant increase in time spent on physical activities in the intervention group from spending 60 minutes of physical activities less than five days per week to five to seven days per week $(p<0.001)$. Table 3 shows questions answered by the participants regarding their screen time and physical activity behaviors.

\section{Attendance}

Average attendance rate was $91 \%$. The highest attendance was $100 \%$ of the intervention sessions and the lowest was $63 \%$. Only participants with attendance rate of $80 \%$ or higher were included in the final analysis.

\section{Discussion}

At baseline, physical activities in both camps $78.9 \%$ from comparison group and $82 \%$ from intervention group did not meet the recommended 60 minutes of physical activity per day. On the other hand, $78.9 \%$ of the comparison group and $79.5 \%$ of the intervention group spend 3 or more hours watching screen including TV, IPad, or other 
devices. Both groups also had no knowledge regarding the amount of time to spend on physical activities or the screen time.

After 8 weeks of summer camp, significant increase in time spent on physical activity by the participants for 1 hour 5-7 days a week. Significant reduction in screen time to the recommended for no more than 2 hours per day was reported. There was a significant increase in the participants knowledge regarding the recommended time spend on screen or physical activity and the benefits of physical activities.

Several studies in the literature supported the results of this study. Significant increase in the participants time spent on physical activity during their free time even during the weekend (Sigmund, El Ansari, \& Sigmundová, 2012; Speroni, Tea, Earley, Niehoff, \& Atherton, 2008; Dzewaltowski, Rosenkranz, Geller, Coleman, Welk, et al. 2010). McCallum et al. (2006) implemented a 12-week intervention targeting weight gain prevention in overweight and obese children. No significant increase in participants physical activity or BMI reduction was observed. The results maybe be due to population chosen was overweight and obese children that may have harder time accepting lifestyle changes. Olven et al. (2010) assessed the effectiveness of a summer camp intervention in promoting physical activity and fitness score of 37 participant. The summer camp included nutrition education classes, physical activities, and self-esteem activities. Significant changes in BMI, waist circumference, physical activity, and fitness were seen $(p<0.05)$

Most interventions are school based and only few interventions were conducted in summer camps were children had free time. No studies have been done in Kuwait as a nutrition education intervention. The groups were randomly assigned to intervention or 
comparison groups, and there was no significant difference between the two groups in regard to sociodemographic status. Low dropout rate by only two participants from the intervention group due to attending less than $80 \%$ of the classes.

Study limitation includes, desired sample size of 140 participants was not met, and only 79 participated due to long follow-up period and people in Kuwait tend to travel during summer break. There was a significant difference in the mother's BMI. The comparison group have significantly more overweight mothers than the intervention group which had more normal weight mothers, and that might have affected the comparability of the results. This study also is lacking long term follow-up to observe if the results were sustainable for the long-term.

In conclusion, the purpose of this study was to assess the effectiveness of an eight weeks intervention at "My Healthy Habits" summer camp on improving the participant's physical activity and screen time knowledge and behavior. The results of this study showed that eight weeks of "My Healthy Habits" summer camp was affective in improving physical activity and screen time knowledge and behavior for children aged 610 years in Kuwait during summer break. which in the long run can help preventing obesity and its related diseases (seal and seal, 2011). Long-term follow-up is recommended to check the sustainability of these results.

Table 1. Children's Baseline demographic characteristics by treatment Group (N=77)

\begin{tabular}{|l|l|l|l|}
\hline Characteristics & Comparison G & Intervention Groy & P-Value \\
\cline { 2 - 3 } & $\mathbf{n = 3 8}$ & $\mathbf{n = 3 9}$ & \\
\hline Age in years & $7.05 \pm 1.4$ & $7.41 \pm 1.46$ & 0.357 \\
\hline
\end{tabular}




\begin{tabular}{|l|l|l|l|}
\hline Nationality & & & 0.141 \\
\hline Kuwaiti & $94.7(36)$ & $89.7(35)$ & \\
\hline Other & $5.3(2)$ & $10.3(4)$ & \\
\hline Gender & & & 0.721 \\
\hline Male & $42.1(16)$ & $46.2(18)$ & \\
\hline Female & $57.9(22)$ & $53.8(21)$ & \\
\hline Order in the family & $2 \pm 1$ & $2 \pm 1$ & 0.924 \\
\hline Nutrition Education & & & \\
\hline No & $100(38)$ & $100(39)$ & \\
\hline Yes & $0(0)$ & $0(0)$ & \\
\hline
\end{tabular}

Continuous variable (age) is presented as mean \pm SD and categorical variables as percentage (n). Level of significance set at $P<0.05$.

Table 2. Mothers' baseline demographic characteristics by treatment Group $(\mathrm{N}=77)$

\begin{tabular}{|l|l|l|l|}
\hline Characteristic & Comparison G & Intervention Grou & P-Value \\
\cline { 2 - 3 } & $\mathbf{n = 3 8}$ & $\mathbf{n = 3 9}$ & \\
\hline Age in years & $35.58 \pm 4.89$ & $34.44 \pm 4.19$ & 0.448 \\
\hline Nationality & & & 0.052 \\
\hline Kuwaiti & $97.4(37)$ & $84.6(33)$ & \\
\hline Other & $2.6(1)$ & $15.4(6)$ & \\
\hline Marital status & & & 0.299 \\
\hline Married & $86.6(33)$ & $94.9(37)$ & \\
\hline Divorced & $7.9(3)$ & $5.1(2)$ & \\
\hline Number of children & $3 \pm 1$ & $3 \pm 1$ & 0.823 \\
\hline BMI & & & $0.008 *$ \\
\hline Underweight & $0(0)$ & $5.1(2)$ & \\
\hline Normal & $26.3(10)$ & $59(23)$ & \\
\hline Overweight & $52.6(20)$ & $25.6(10)$ & \\
\hline Obese & $21.1(8)$ & $10.3(4)$ & \\
\hline Education level & & & 0.511 \\
\hline High school or below & $10.5(4)$ & $5.1(2)$ & \\
\hline 2 years diploma & $26.3(10)$ & $23.1(9)$ & \\
\hline Bachelor degree & $55.3(21)$ & $53.8(21)$ & \\
\hline Graduate level & $7.9(3)$ & $17.9(7)$ & \\
\hline Monthly household income & & & \\
\hline & & & \\
\hline
\end{tabular}




\begin{tabular}{|c|l|l|l|}
\hline$<2000 \mathrm{KD}$ & $15.8(6)$ & $2.6(1)$ & \\
\hline $2000-3000 \mathrm{KD}$ & $47.4(18)$ & $69.2(27)$ & \\
\hline$>3000 \mathrm{KD}$ & $36.8(14)$ & $28.2(11)$ & \\
\hline Working status & & & 0.689 \\
\hline House wife & $31.6(12)$ & $35.9(14)$ & \\
\hline Working outside home & $68.4(38)$ & $64.1(25)$ & \\
\hline Nutrition Education & & & 0.094 \\
\hline No & $78.9(30)$ & $92.3(36)$ & \\
\hline Yes & $21.1(8)$ & $7.7(3)$ & \\
\hline
\end{tabular}

Continuous variable (age) is presented as mean \pm SD and categorical variables as percentage (n). ${ }^{*}$ Level of significance set at $P<0.05$. 
Table 3. Participants knowledge and behavior change related to physical activity and screen time at baseline and postintervention

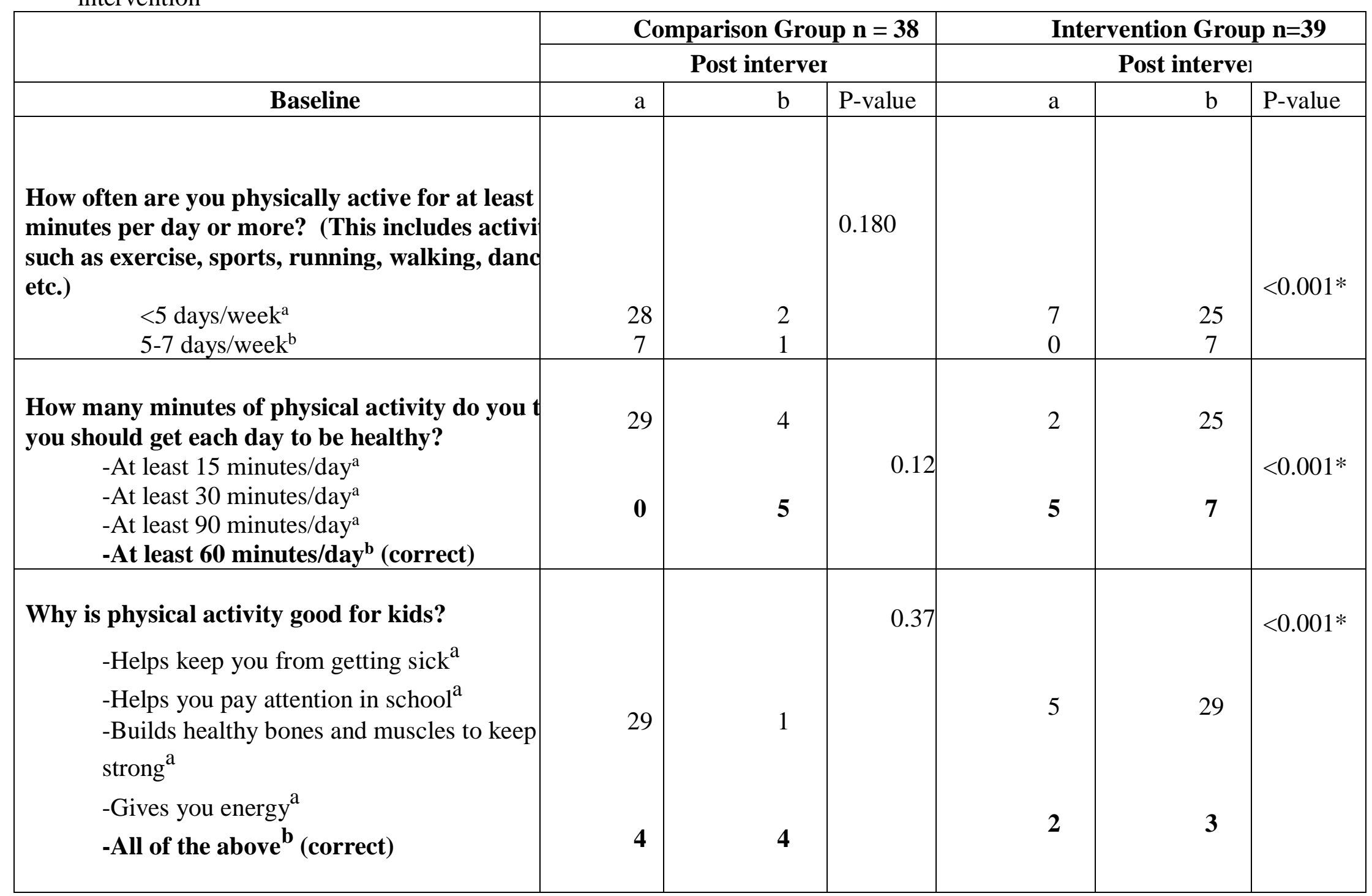




\begin{tabular}{|c|c|c|c|c|c|c|}
\hline $\begin{array}{l}\text { Yesterday, I watched the screen (TV, IPad, } \\
\text { videogames, cinema, etc.) for: } \\
\qquad \begin{array}{c}2 \text { hours or less } \\
\text { a } \\
3 \text { hours or more }\end{array}\end{array}$ & $\begin{array}{c}5 \\
28\end{array}$ & $\begin{array}{l}3 \\
2\end{array}$ & 0.453 & $\begin{array}{c}1 \\
22\end{array}$ & $\begin{array}{l}9 \\
7\end{array}$ & $<0.001 *$ \\
\hline $\begin{array}{l}\text { How many hours of screen time do you think yd } \\
\text { shouldn't exceed each day to be healthy? } \\
\qquad \begin{array}{l}2 \text { hours } \\
\text { a (correct) } \\
3 \text { hours }{ }^{b} \\
4 \text { hours }{ }^{b} \\
\text { screen time has nothing to do with health }^{b}\end{array}\end{array}$ & 30 & 2 & 0.68 & 7 & $\mathbf{0}$ & $<0.001 *$ \\
\hline
\end{tabular}




\section{References}

Allafi, A., Al-Haifi, A., Al-Fayez, M., Al-Athari, B., Al-Ajmi, F., Al-Hazzaa, H., . . Ahmed, F. (2014). Physical activity, sedentary behaviours and dietary habits among Kuwaiti adolescents: Gender differences. Public Health Nutrition, 17(9), 2045-2052.

Bandura, A. (1993). Social foundations of thought and action: A social cognitive theory. Englewood Cliffs, NJ: Prentice-Hall.

Dzewaltowski, D. A., Rosenkranz, R. R., Geller, K. S., Coleman, K. J., Welk, G. J., Hastmann, T. J., Milliken, G. A. (2010). HOP'N after-school project: an obesity prevention randomized controlled trial. The International Journal of Behavioral Nutrition and Physical Activity, 7(90), 1 - 12.

CATCH. (2014). CATCH PE: Resources for the Physical Educator. Available at http://catchinfo.org/wp-content/uploads/2014/10/Catch-PEnew.pdf. Accessed 14 March 2017.

CDC. (2012). Oklahoma State Nutrition, Physical Activity, and Obesity Profile. Available at http://www.cdc.gov/obesity/stateprograms/fundedstates/pdf/Oklahoma-StateProfile.pdf. Accessed 24 October 2016.

CDC. (2016). Overweight \& Obesity. Available at https://www.cdc.gov/obesity/childhood/defining.html. Accessed 23 January 2018.

Hall, E., Chai, W., Koszewski, W., \& Albrecht, J. (2015). Development and validation of a social cognitive theory-based survey for elementary nutrition education program. The International Journal of Behavioral Nutrition and Physical Activity, 12(47), 1-12.

Kelsey, M. M., Zaepfel, A., Bjornstad, P., \& Nadeau, K. J. (2014). Age-Related Consequences of Childhood Obesity. Gerontology, 60(3), 222-228.

Mccallum, Z., Wake, M., Gerner, B., Baur, L. A., Gibbons, K., Gold, L., . . . Waters, E. (2006). Outcome data from the LEAP (Live, Eat and Play) trial: a randomized controlled trial of a primary care intervention for childhood overweight/mild obesity. International Journal of Obesity, 31(4), 630-636.

Robinson, T.N., Matheson, D.M., Kraemer, H.C., et al., 2010. A randomized controlled trial of culturally tailored dance and reducing screen time to prevent weight gain in low-income African American girls: Stanford GEMS. Arch. Pediatr. Adolesc. Med. 164 (11), 995-1004. 
US Department of Health and Human Services, 2008. Physical Activity Guidelines for Americans.

Olvera N, Scherer R, McLeod J, et al. (2010). BOUNCE: an exploratory healthy lifestyle summer intervention for girls. Am J Health Behav,34, 44-55.

Outcome data from the LEAP (Live, Eat and Play) trial: a randomized controlled trial of a primary care intervention for childhood overweight/mild obesity. Z McCallum, M Wake, B Gerner, L A Baur, K Gibbons, L Gold, J Gunn, C Harris, G Naughton, C Riess, L Sanci, J Sheehan, O C Ukoumunne \& E Waters. International Journal of Obesity(2007) 31, 630-636 (2007)

Sigmund, E., El Ansari, W., \& Sigmundová, D. (2012). Does school-based physical activity decrease overweight and obesity in children aged 6-9 years? A two-year non-randomized longitudinal intervention study in the Czech Republic. $B M C$ Public Health, 12(570), 1-12.

WHO. (2017). Obesity and overweight. Available at http://www.who.int/mediacentre/factsheets/fs311/en/. Accessed 10 November 2017. 


\section{CHAPTER VI: The effect of "My Healthy Habits" summer camp on the participants BMI percentile and Waist-to-Height ratio.}

\section{Introduction}

Childhood obesity has become a global public health problem with its rapid increase over the last decade. Studies have shown that overweight and obese children are likely to grow up as obese adults. Overweight and obesity is also associated with chronic diseases such as diabetes, musculoskeletal, cancer, and cardiovascular diseases which are the leading causes of death in the world. Childhood obesity was even seen to be related to premature death and disability in adulthood. Obesity causes difficulty in breathing, increasing chances of having fractures, hypertension, insulin resistance, cardiovascular diseases and psychological problems (WHO, 2017 a). Middle East region in 2017 was ranked the second highest region for obesity, and Kuwait was ranked number 11 most obese country worldwide with $39.7 \%$ of Kuwaiti adults being obese, and $21.6 \%$ of children ages $6-18$ years are overweight and $30.5 \%$ are obese (Renew Bariatrics, 2017; Elkum et al., 2016). The main reason behind the raise in childhood obesity is changing of the lifestyle and increased consumption of food high in sugar and fat and decreased consumption of foods rich in vitamins, minerals, and other nutrients. Additionally, increased time spent on screen and decreased time spent on Physical activities are contributing factors (WHO, 2017 a).

With rapidly increasing prevalence of obesity, WHO considered childhood obesity to be a global epidemic and preventing it should be a priority (Wang, $\mathrm{Wu}$, Wilson, Bleich, Cheskin, et al., 2013). Fortunately, overweight and obesity can be 
prevented by educating the community and providing supportive environment to follow a healthy diet and be physically active by making it accessible and (WHO, 2017 a).

Childhood obesity prevention interventions were to be effective in reducing obesity for children when it included nutrition education and an hour of physical activities, five days a week (Tarro, Llauradó, Albaladejo, Moriña, Arija, et al., 2014; Sigmund, El Ansari, \& Sigmundová, 2012; Speroni, Tea, Earley, Niehoff, \& Atherton, 2008). The Children's Health and Activity Modification Program “C.H.A.M.P.” is one of the interventions that included nutrition education and physical activity for 4 weeks. The intervention resulted in significant decrease in children's BMI-z score $(\mathrm{p}<0.05)$ from baseline to post-intervention (Gately, Cooke, Butterly, Mackreth, \& Carroll, 2000).

Child obesity research is important because the literature provides strong evidence that supports the need to fight childhood obesity to prevent nutrition related chronic diseases especially if the child has a sedentary lifestyle (Dudley, Cotton, \& Peralta, 2015). The literature also provided ample evidence that healthy eating is very important in school age children for their optimal growth, to build healthy bodies, strong bones, and strong immunity (Dudley, et al., 2015). The importance of establishing healthy eating habits early on as these habits tend to grow with the children into adulthood need to be emphasized (Neumark-Sztainer, Wall, Larson, Eisenberg, Loth, 2011; Nicklaus, \& Remy, 2013). 
Studies have shown that children gain double the weight during summer break than they do during school year (Von Hippel, Powell, Downey, \& Rowland, 2007; Moreno, Johnston, \& Woehler, 2013; Smith, Bartee, Dorozynski, \& Carr, 2009). Interventions designed for the free time of the child such as after school programs or summer camps showed to be successful in preventing overweight and obesity, increasing the consumption of fruit and vegetables intake, increasing physical activity, and showing statistical differences in some of the weight related outcomes (Moreno, Vézina-Im, Vaughan, \& Baranowski, 2017). Findings suggests that summer camp based childhood obesity prevention programs may be successful in fighting childhood obesity. Therefore, implementing an obesity prevention program that include physical activity and nutrition education during summer seems promising in preventing childhood obesity. The aim of this study was to assess the effectiveness of an eight-week intervention at a summer camp on the participants BMI percentile and waist-to-height in Kuwait.

\section{Methods}

\section{Subject Recruitment}

Eight-week randomized control trial was conducted during summer 2017 (July August) with "intervention" and "comparison" groups. Participating summer-camps were selected from Mathllah Expo the largest annual summer-camps expo specialized in the development of child's skills in Kuwait. Summer-camps that were interested and eligible for this study were contacted. Two comparable summer camps in regard to the activities they offer, socioeconomic status, serving both genders, at the age between 6-10 years in 
Kuwait were selected to participate in the study. One camp was randomly assigned to intervention group and the other to comparison group. Convenient sampling was used to recruit participants attending the two summer camps who wish to participate and meet the eligibility criteria. Pre-test/post-test screening was done for the participants in the intervention and comparison groups.

A total of 89 participants were screened, 79 were eligible for the study based on the inclusion/exclusion criteria; 4 in the intervention group are joining the camp for less than 2 months and 2 from the comparison group, 2 from the intervention group with chronic diseases ( 1 diabetes and 1 heart disease), and 2 from the control group diseases (1 diabetes and 1 G6PD), 41 from the intervention group and 38 from the comparison group participated in this study. Two participants in the intervention group due to attendance rate less than $80 \%$ were excluded. Therefore, data from 79 participants were included in the analysis of this intervention.

Participant were $6-10$ years old, attending the participating summer camps, willing to participate in an 8 week of intervention (from July 2nd to August 31st, 2017) and data collection pre-and post- intervention, willing and able to participate in physical activities, and provided parent consent and child assent. Children who did not meet the inclusion criteria, inability to participate in physical activity, suffering from a chronic disease, physical or mental disability were excluded. The required assessments took place at the same summer camps the children were attending (week 0) one week before the intervention, and (week 9) 1 week post intervention.

Children attending the participating summer camps received a flyer about the study. Information included what the study was about, when it would be conducted, why, 
where, and by whom. It also included contact information if they were interested in participating they could contact the investigator. Written consent and assent forms were given to parents and children for review and signatures in order to participate in the study. Approval was obtained from Institutional Review Board at Florida International University (FIU IRB number: IRB-17-0197). Demographic questionnaire was obtained from the parents and they were informed that all of the information is confidential at all the times.

From the intervention summer camp, 41 children participated in the preassessment followed by eight weeks of intervention including nutrition education and physical activities two days a week for eight weeks. While the comparison group, 38 children participated in the pre-assessment and they continued regular summer-camp activities without any kind of intervention for eight weeks. After the eight weeks, 39 children from intervention group and 38 children from the comparison group received post intervention assessment.

\section{Interventions}

Physical activity: The physical activity sessions were conducted four days a week for 20 minutes per day. Sessions focused on motivating children to engage in moderate to vigorous physical activities (MVPA). The activities were developed based on CATCH physical education activity box which provides more than 300 age appropriate 
fun games and activities. These activities included: worm up, flexibility, muscle strength, endurance, aerobic games, fitness, and cool down exercises (CATCH, 2014).

Nutrition Education: The nutrition education sessions were conducted by the principle investigator 2 days a week for 40 minutes per day; the first 20 minutes were discussion and interaction about the topic of the week and the second 20 minutes were for hands on activities related to the topic. The nutrition education sessions provided information and activities emphasizing the importance of healthy eating using the social cognitive theory. It is based on the idea that behavior change results from the dynamic interactions between individuals and their environments (Bandura,1993). The lessons were from CATCH Kids Club nutrition curriculum. The sessions were divided into themes, and delivered in the form of group learning games, individual practices, stories, discussions, skill building activities, and goal setting. The topics covered included: My plate, food groups, sugary beverages vs water, screen time, physical activity.

\section{Measures}

Socio-demographic questionnaire: After signing the consent forms, parents were asked to fill out the sociodemographic questionnaire at baseline (week 0). The age, gender, income, number of siblings, the child's rank in the family, and nutrition background learned from nutrition education classes for the child and the mother.

BMI percentile: The children's height and weight were measured using the same stadiometer for pre-intervention and post-intervention. The stadiometer was placed behind a partition in a hard-even floor. Children's weight was measured in light clothing 
without shoes. The children stood on the scale with their feet slightly apart and not touching anything. The weight was measured to the nearest $0.1 \mathrm{~kg}$. Height of the children was measured standing straight, head straight, and their back against the stadiometer without shoes and hair accessories that can affect the child's height, and the height was recorded to the nearest $0.1 \mathrm{~cm}$. BMI-for-age percentile was calculated by using WHO BMI AnthroPlus software (WHO, 2017b). BMI-for age percentile helped to assess if the intervention was effective in reducing the weight of the participants (Fryar, Gu, \& Ogden, 2012).

Waist-to-height ratio (WHtR): WHtR was used to assess central obesity in the children since it is a cost-effective way for measuring central obesity (Magalhães et al., 2014). The children's waist circumference was measured behind a partition using measuring tape at the uppermost lateral border of the hip crest. A cutoff point of 0.5 has been established to indicate central obesity if the child has a value greater than 0.5 (Fryar, et al., 2012).

\section{Statistical analysis}

The independent variables were the nutrition education and physical activity classes. The dependent variables were the participants BMI percentile and WHtR. The intervention group was the group of participants that received the nutrition education and physical activities intervention for 8 weeks. The comparison group was the group that did not receive any kind of intervention.

For descriptive statistics, chi squared test for categorical variables and independent t-test for continues variables were used in the demographic characteristics. 
To study the effect of participating in the intervention, paired t-test was used to determine changes in participants height, weight, waist circumference, BMI percentile and waist-toheight ratio before and after the intervention between intervention and comparison groups. Chi square test was used for the distributions of subjects' BMI category and central obesity, pre- and post-intervention in comparison and intervention groups. since we had 0 participants with underweight post intervention in the intervention group, underweight cases in the control group $(n=3)$ were merged with normal weight group to be able to analyze.

Multiple regression was used to see the effect of age and gender on participants BMI percentile difference (after-before). Boxplot was used to show BMI percentile difference before and after intervention between intervention and comparison groups. The significance level for outcomes was set on $\mathrm{p}<0.05$. The statistical analysis was done using SPSS 23.0.

\section{Results}

\section{Baseline sociodemographic characteristics}

Baseline sociodemographic characteristics are summarized in table 1 for children and in table 2 for the mothers. It showed that there was no significant difference between the two groups in regard to age ( $7.05 \pm 1.4$ years, for comparison group and $7.41 \pm 1.46$ years for intervention group, $p=0.367)$, Kuwaiti nationality (94.7\% vs. $89.7 \%$ for comparison and intervention groups respectively, $p=0.141)$ gender $(p=0.721)$, or the order of the child in the family $(2 \pm 1 p=0.924)$. It also showed that none of the children received any kind of nutrition education before. 
There were no significant differences in the sociodemographic variables between the intervention and comparison groups. More mothers in the comparison group were overweight (52.6\%), while $25.6 \%$ of overweight mothers in the intervention group, $(p=0.008)$. The mean age of the mothers was $35.6 \pm 4.9$ years $(p=0.448)$, majority of the mothers were Kuwaiti (97.4\% vs. 84.6\% for comparison and intervention groups respectively, $p=0.052$ ), $86.6 \%$ and $94.9 \%$ of the mothers were married for comparison and intervention groups respectively $(p=0.299)$. The mean number of children was $3 \pm 1$ for both groups $(p=0.823$ ). Majority of the mothers had bachelor's degree $55.3 \%$ for comparison group and $53.8 \%$ for the intervention group $(p=0.511)$. Most of the families had middle income (2000-3000 KD/month, $p=0.057)$. Sixty-Eight-point-four percent of the mothers in the comparison group and $64.1 \%$ in the intervention group were working $(p=0.689)$ and the majority did not receive nutrition education classes before $(78.9 \%$ and $92.3 \%$ respectively, $p=0.094)$.

\section{Weight, height, and BMI}

Table 3 shows that the mean weight for the comparison group has increased significantly by $0.44 \mathrm{~kg}$ after 8 weeks of the study from $27.53 \pm 7.67$ to $28.03 \pm 7.73$ $(p<0.001)$, while the intervention group mean weight decreased slightly by $0.19 \mathrm{~kg}$, the mean weight at baseline was $29.97 \pm 8.99$ and post intervention was $29.77 \pm 8.66$ $(p=0.036)$. The height of the participants increased in both groups by $0.44 \mathrm{~cm}$ in the comparison group and $0.37 \mathrm{~cm}$ in the intervention group $(p<0.001)$. The participants $\mathrm{BMI}$ has increased by 0.14 in the comparison group from $17.38 \pm 2.86$ to $17.53 \pm 2.87$ 
$(\mathrm{p}=0.006)$, while decreased in the intervention group by 0.21 from $17.96 \pm 2.84$ to

17.75 $\pm 2.73(\mathrm{p}=0.001)$, Figure 1 .

Table 4 shows the distribution of subjects' BMI category, pre- and postintervention in comparison and intervention groups. There was no significant difference in the BMI categories between the intervention and comparison groups at baseline $(p=0.566)$ nor at post-intervention $(p=0.588)$.

The regression analysis in table 6 shows that neither age nor gender had an effect on the participants $\mathrm{BMI}(p=0.36, p=0.65$ respectively $)$.

\section{Waist circumference and waist-to-height ratio}

Table 3 shows that the mean waist circumference has increased significantly by $0.39 \mathrm{~cm}$ in the comparison group $(\mathrm{p}<0.001)$, while significantly decreased by $0.35 \mathrm{~cm}$ in the intervention group ( $p=0.008)$. waist-to-height ratio increased in the comparison group by 0.01 but not significantly from $0.48 \pm 0.05$ to $0.49 \pm 0.08$ ( $p=0.22)$, while decreased by 0.01 in the intervention group from $0.49 \pm 0.04$ to $0.48 \pm 0.04(p=0.001)$.

The distributions of subjects' central obesity, pre- and post-intervention in comparison and intervention groups are shown in table 5. There was no significant difference between the intervention and comparison group central obesity before intervention $(p=0.575)$ or after intervention $(p=0.195)$.

\section{Attendance}

Average attendance rate was $91 \%$. The highest attendance was $100 \%$ of the 
intervention sessions and the lowest was $63 \%$. Only participants with attendance rate of $80 \%$ or higher were included in the analysis.

\section{Discussion}

Von Hippel et al. (2007) and Moreno et al (2013) illustrated that children tend to gain weight during summer break due to changes is children's lifestyle. This was seen by a mean weight gain of $0.44 \mathrm{~kg}$ after 2 months of summer break in the comparison group of our study $(p<0.001)$. One of the aim of "My Healthy Habits" summer camp was to prevent weight gain related to child's lifestyle changes during summer break. Our findings showed significant reduction in participants weight by $0.19 \mathrm{~kg}$ and BMI by 0.21 ( $p=0.036, p=0.001$ respectively) in the intervention group. Significant reduction of 0.35 $\mathrm{cm}$ was seen in waist circumference $(p=0.008)$, and significant reduction in WHtR by $0.01(p=0.001)$ in intervention group. However, participants' age or gender were not factors affecting BMI change in this study $(p=0.36, p=0.604)$.

The literature reports conflicting results regarding the effect of nutrition education and physical activity interventions on children's BMI and WHtR. Baranowski et al. (2003) reported no significant difference in participants BMI between the treatment and control groups after a 4 or 12 week of intervention. On the other hand, Olvera et al. (2010) demonstrated significant changes in their participants' BMI and waist circumference $(\mathrm{p}<0.05)$ after attending nutrition education and physical activity summer camp for 3 weeks. Southam et al. (1984) reported the effectiveness of an eight-week summer camp intervention in reducing weight, percent of overweight and skinfold thickness in 25 overweight adolescents participated in 4 hours, 4 days a week of nutrition 
education and physical activity. George, Schneider, and Kaiser (2016) investigated the effect of 6-week summer camp focusing on nutrition education 3 hours/ week and physical activity 3 hours/day on 126 overweight and obese participants. Significant reduction was seen in $\mathrm{WHtR}$ from 0.64 to $0.61(p<0.001)$.

Strengths of this study include that there were no studies conducted in Kuwait as a nutrition education intervention. The groups were randomly assigned to intervention or comparison groups, and there was no significant difference between the two groups in regard to sociodemographic status, baseline BMI categories, or WHtR. Low dropout rate (only two participants from the intervention group) due to attending less than $80 \%$ of the classes.

Study limitation includes, desired sample size of 140 participants was not met, and only 79 participated due to long follow-up period and people in Kuwait tend to travel during summer break. There was a significant difference in the mother's BMI. The comparison group had significantly more overweight mothers than the intervention group mothers which had more normal weight mothers, and that might have affected the comparability of the results. This study is lacking long term follow-up to observe if the results were sustainable.

In conclusion, "My Healthy Habits" summer camp can be an effective approach to preventing childhood overweight and obesity. Long term follow-up is recommended to determine the long-term effect of the intervention on the participants BMI and WHtR.

Table 1. Children's Baseline demographic characteristics by treatment Group (N=77)

\begin{tabular}{|l|l|l|l|}
\hline Characteristics & Comparison G & Intervention Grou & P-Value \\
\hline
\end{tabular}




\begin{tabular}{|l|l|l|l|}
\hline & $\mathbf{n = 3 8}$ & $\mathbf{n = 3 9}$ & \\
\hline Age in years & $7.05 \pm 1.4$ & $7.41 \pm 1.46$ & 0.357 \\
\hline Nationality & & & 0.141 \\
\hline Kuwaiti & $94.7(36)$ & $89.7(35)$ & \\
\hline Other & $5.3(2)$ & $10.3(4)$ & \\
\hline Gender & & & 0.721 \\
\hline Male & $42.1(16)$ & $46.2(18)$ & \\
\hline Female & $57.9(22)$ & $53.8(21)$ & \\
\hline Order in the family Mean (S & $2 \pm 1$ & $2 \pm 1$ & 0.924 \\
\hline Nutrition Education & & & \\
\hline No & $100(38)$ & $100(39)$ & \\
\hline Yes & $0(0)$ & $0(0)$ & \\
\hline
\end{tabular}

Continuous variable (age) is presented as mean $\pm \mathrm{SD}$ and categorical variables as percentage (n). Level of significance set at $P<0.05$.

Abbreviations: $\mathrm{SD}=$ Standard Deviation

Table 2. Mothers' baseline demographic characteristics by treatment Group $(\mathrm{N}=77)$

\begin{tabular}{|l|l|l|l|}
\hline \multirow{2}{*}{ Characteristic } & Comparison G & Intervention Grou & P-Value \\
\cline { 2 - 3 } & $\mathbf{n = 3 8}$ & $\mathbf{n = 3 9}$ & \\
\hline Age in years & $35.58 \pm 4.89$ & $34.44 \pm 4.19$ & 0.448 \\
\hline Nationality & & & 0.052 \\
\hline Kuwaiti & $97.4(37)$ & $84.6(33)$ & \\
\hline Other & $2.6(1)$ & $15.4(6)$ & \\
\hline Marital status & & & 0.299 \\
\hline Married & $86.6(33)$ & $94.9(37)$ & \\
\hline Divorced & $7.9(3)$ & $5.1(2)$ & \\
\hline Number of children & $3 \pm 1$ & $3 \pm 1$ & 0.823 \\
\hline BMI & & & $0.008 *$ \\
\hline Underweight & $0(0)$ & $5.1(2)$ & \\
\hline Normal & $26.3(10)$ & $59(23)$ & \\
\hline Overweight & $52.6(20)$ & $25.6(10)$ & \\
\hline Obese & $21.1(8)$ & $10.3(4)$ & \\
\hline Education level & & & \\
\hline High school or below & $10.5(4)$ & $5.1(2)$ & \\
\hline 2 years diploma & $26.3(10)$ & $23.1(9)$ & \\
\hline Bachelor degree & $55.3(21)$ & $53.8(21)$ & \\
\hline
\end{tabular}




\begin{tabular}{|c|l|l|l|}
\hline Graduate level & $7.9(3)$ & $17.9(7)$ & \\
\hline Monthly household income & & & 0.057 \\
\hline$<2000 \mathrm{KD}$ & $15.8(6)$ & $2.6(1)$ & \\
\hline $2000-3000 \mathrm{KD}$ & $47.4(18)$ & $69.2(27)$ & \\
\hline$>3000 \mathrm{KD}$ & $36.8(14)$ & $28.2(11)$ & \\
\hline Working status & & & 0.689 \\
\hline House wife & $31.6(12)$ & $35.9(14)$ & \\
\hline working & $68.4(38)$ & $64.1(25)$ & \\
\hline Nutrition Education & & & 0.094 \\
\hline No & $78.9(30)$ & $92.3(36)$ & \\
\hline Yes & $21.1(8)$ & $7.7(3)$ & \\
\hline
\end{tabular}

Continuous variable (age) is presented as mean \pm SD and categorical variables as percentage (n). * Represents significant differences. Level of significance set at $P<0.05$. Abbreviations: $\mathrm{SD}=$ Standard Deviation 
Table 3. Anthropometric measurements by treatment group at baseline and post-intervention

\begin{tabular}{|c|c|c|c|c|c|c|c|c|}
\hline & \multicolumn{4}{|c|}{ Comparison Group $\mathbf{n}=39$} & \multicolumn{4}{|c|}{ Intervention Group $\mathbf{n}=\mathbf{3 8}$} \\
\hline & \multirow[b]{2}{*}{ Baselint } & \multicolumn{2}{|c|}{ Mean diffe } & \multirow[b]{2}{*}{ P-Valı } & \multirow[b]{2}{*}{ Baseline } & \multicolumn{3}{|c|}{ Mean diffe } \\
\hline & & Post Interve] & & & & Post Interver & & P-Val \\
\hline Weight (kg) & $27.53 \pm 7.6$ & $28.03 \pm 7.7$ & 0.44 & $<0.001$ & $29.97 \pm 8.9$ & $29.77 \pm 8.6$ & -0.19 & $0.036 *$ \\
\hline Height (cm) & $124.95 \pm 8$ & $125.37 \pm 8 .$. & 0.44 & $<0.001$ & $127.7 \pm 10.6$ & $128.07 \pm 10$. & 0.37 & $<0.001^{*}$ \\
\hline waist circumference $(\mathrm{cm})$ & $60.5 \pm 8.8$ & $60.97 \pm 8 . \varepsilon$ & .39 & $<0.001$ & $62.64 \pm 9.0$ & $62.29 \pm 8.6$ & -.35 & 0.008 \\
\hline Waist-to-Height ratio & $0.48 \pm 0.0$ & $0.49 \pm 0.0$ & 0.01 & $<0.001$ & $0.49 \pm 0.0$ & $0.48 \pm 0.0$ & -0.01 & 0.001 \\
\hline BMI percentile & $17.38 \pm 2 . \varepsilon$ & $17.52 \pm 2 . \varepsilon$ & 0.14 & 0.006 & $17.96 \pm 2.8$ & $17.75 \pm 2.7$ & -0.21 & 0.001 \\
\hline
\end{tabular}

Paired t-test was used. Data represented by mean \pm SD

* Represents significant differences. Level of significance is at $P<0.05$ 
Table 4. Distributions of subjects' BMI category, pre- and post-intervention in comparison and intervention groups.

\begin{tabular}{|c|c|c|c|c|c|c|}
\hline & \multicolumn{3}{|c|}{ Baseline Groups } & \multicolumn{3}{|c|}{ Post Intervention Groups } \\
\hline Category & $\begin{array}{l}\text { Comparison } \\
\mathrm{n}=38 \\
\text { Percentage (n) }\end{array}$ & $\begin{array}{l}\text { Intervention } \\
\mathbf{n}=\mathbf{3 9} \\
\text { Percentage (n) }\end{array}$ & P-Value & $\begin{array}{l}\text { Comparison } \\
\mathrm{n}=38 \\
\text { Percentage (n) }\end{array}$ & $\begin{array}{l}\text { Intervention } \\
\mathbf{n}=39 \\
\text { Percentage (n) }\end{array}$ & P-Value \\
\hline BMI & & & 0.566 & & & 0.58 \\
\hline Healthy weight & $57.9(22)$ & $59.0(23)$ & & $52.6(20)$ & $64.1(25)$ & \\
\hline Overweight & $26.3(10)$ & $17.9(7)$ & & $31.6(12)$ & $23.1(9)$ & \\
\hline Obese & $15.8(6)$ & $23.1(9)$ & & $15.8(6)$ & $12.8(5)$ & \\
\hline
\end{tabular}

Chi square test was used. Data represented by percentage (n)

Table 5. Distributions of subjects' central obesity, pre- and post-intervention in comparison and intervention groups.

\begin{tabular}{|c|l|l|l|l|l|l|}
\hline & \multicolumn{3}{|c|}{ Baseline Groups } & \multicolumn{3}{c|}{ Post Intervention Groups } \\
\hline Category & $\begin{array}{l}\text { Comparison } \\
\mathbf{n}=38 \\
\text { Percentage (n) }\end{array}$ & $\begin{array}{l}\text { Intervention } \\
\text { n=39 } \\
\text { Percentage (n) }\end{array}$ & P-Value & $\begin{array}{l}\text { Comparison } \\
\text { n=38 } \\
\text { Percentage (n) }\end{array}$ & $\begin{array}{l}\text { Intervention } \\
\mathbf{n = 3 9} \\
\text { Percentage (n) }\end{array}$ & P-Value \\
\hline $\begin{array}{c}\text { Central Obesity } \\
\text { yes }\end{array}$ & $39.5(15)$ & $33.3(13)$ & 0.575 & $39.5(15)$ & $25.6(10)$ \\
no & $60.5(23)$ & $66.7(26)$ & $60.5(23)$ & $74.4(29)$ \\
\hline
\end{tabular}

Chi square test was used. Data represented by percentage (n) 
Table 6 . The effect of age and gender on participants BMI percentile

\begin{tabular}{|c|c|c|c|c|}
\hline & & Unstandardized Coef & $\begin{array}{l}\text { Standardi } \\
\text { Coefficier }\end{array}$ & \\
\hline group & variables & Std. Err & Beta & Sig. \\
\hline \multicolumn{5}{|c|}{$\begin{array}{c}\text { comparison (Constant) } \\
\text { age } \\
\text { gender }\end{array}$} \\
\hline Intervention & $\begin{array}{l}\text { (Constant) } \\
\text { age } \\
\text { gender }\end{array}$ & & & \\
\hline
\end{tabular}

Multiple regression was used

Dependent Variable: BMI percentile difference

Graph 1. BMI percentile difference before and after intervention between intervention and comparison groups

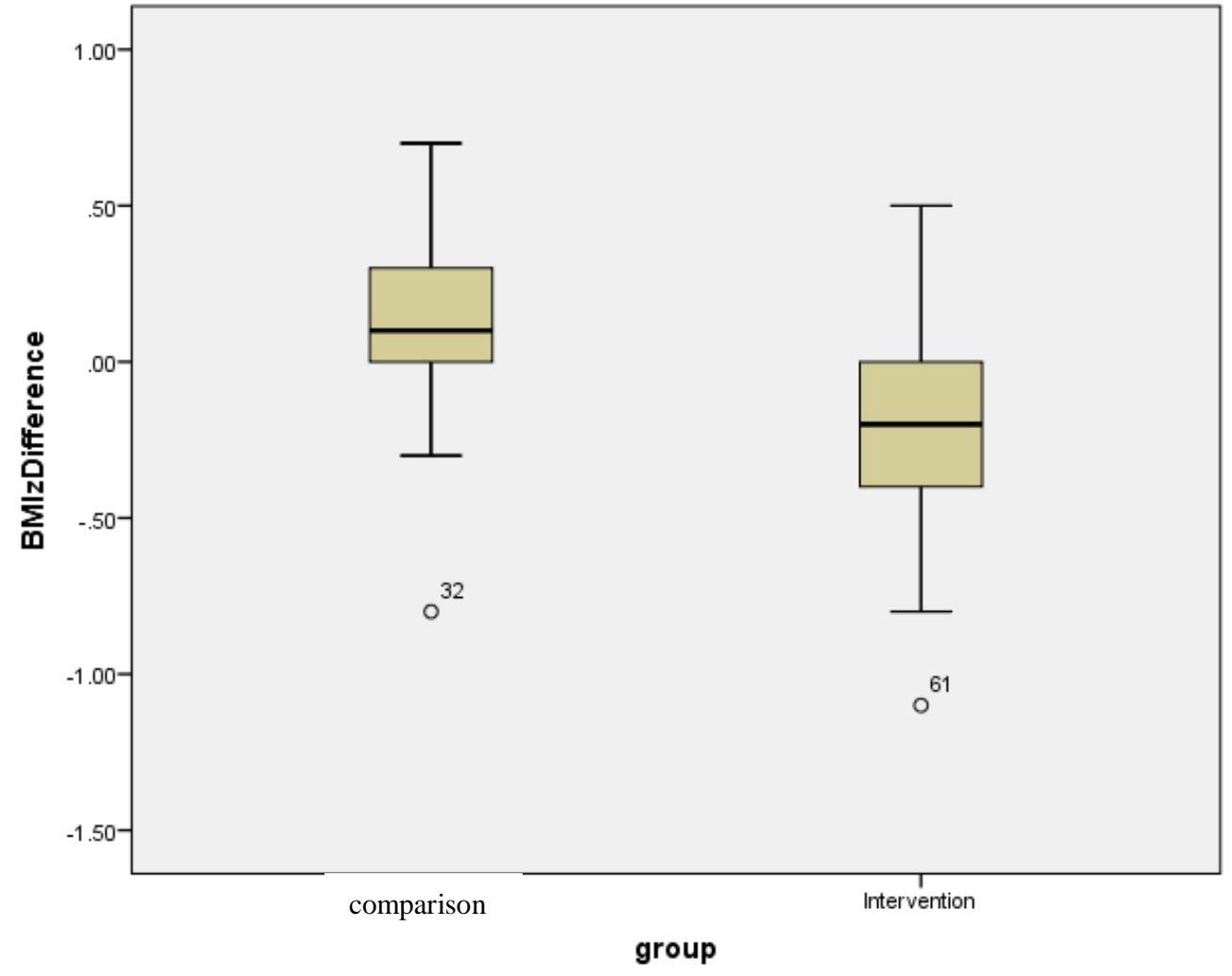




\section{References}

Baranowski T, Baranowski JC, Cullen KW, et al. Tarro, L., Llauradó, E., Albaladejo, R., Moriña, D., Arija, V., Solà, R., Giralt, M. (2014). A primary-school-based study to reduce the prevalence of childhood obesity - the EdAl (Educació en Alimentació) study: a randomized controlled trial. Trials, 15(1), 58.

Bandura, A. (1993). Social foundations of thought and action: A social cognitive theory. Englewood Cliffs, NJ: Prentice-Hall.

Baranowski T, Baranowski JC, Cullen KW, et al. (2003). The fun, food, and fittness project (FFFP): the Baylor GEMS pilot study. Ethnic Disease, 13(1), 30-39

Dudley, D. A., Cotton, W. G., \& Peralta, L.R. (2015), Teaching approaches and strategies that promote healthy eating in primary school children: a systematic review and meta-analysis. The International Journal of Behavioral Nutrition and Physical Activity, 12(28), 1-28.

Elkum, N., Al-Arouj, M., Sharifi, M., Shaltout, A., and Bennakhi, A. (2016) Prevalence of childhood obesity in the state of Kuwait. Pediatric Obesity, 11, 30-34.

Fryar, C. D., Gu, Q., \& Ogden, C. L. (2012). Anthropometric reference data for children and adults: United States, 2007-2010. National Center for Health Statistics. Vital Health Stat, 11(252).

Gately, P. J., Cooke, C. B., Butterly, R. J., Mackreth, P., \& Carroll, S. (2000). The effects of a children's summer camp programme on weight loss, with a 10 month followup. International Journal of Obesity \& Related Metabolic Disorders, 24(11), 1445-1452.

George GL, Schneider C, Kaiser L. (2016). Healthy lifestyle tness camp: a summer approach to prevent obesity in low-income youth. J Nutr Educ Behav,48, 208212.

Moreno, J. P., Vézina-Im, L., Vaughan, E. M., \& Baranowski, T. (2017). Impact of child summertime obesity interventions on body mass index, and weight-related behaviours: a systematic review and meta-analysis protocol. BMJ Open, 7(10).

Neumark-Sztainer, D., Wall, M., Larson, N. I., Eisenberg, M. E., \& Loth, K. (2011). Dieting and disordered eating behaviors from adolescence to young adulthood: findings from a 10-year longitudinal study. Journal of American Dietetic Association, 111(7), 1004-1011. 
Nicklaus, S., \& Remy, E. Early origins of overeating: tracking between early food habits and later eating patterns. Current Obesity Reports, 2(2), 179-184.

Olvera N, Scherer R, McLeod J, et al. (2010). BOUNCE: an exploratory healthy lifestyle summer intervention for girls. Am J Health Behav, 34, 44-55.

Re:new Bariatrics. (2017). REPORT: OBESITY RATES BY COUNTRY - 2017.

Available at https://renewbariatrics.com/obesity-rank-by-countries/. Accessed 10 November 2017.

Sigmund, E., El Ansari, W., \& Sigmundová, D. (2012). Does school-based physical activity decrease overweight and obesity in children aged 6-9 years? A two-year non-randomized longitudinal intervention study in the Czech Republic. BMC Public Health, 12(570), 1-12.

Smith DT, Bartee RT, Dorozynski CM, Carr LJ. (2009). Prevalence of overweight and influence of out-of-school seasonal periods on body mass index among American Indian schoolchildren. Prev Chronic Dis,6(1), A20.

Southam MA, Kirkley BG, Murchison A, et al. (1984). A summer day camp approach to adolescent weight loss. Adolescence, 19, 855-68.

von Hippel PT, Powell B, Downey DB, Rowland NJ. (2007). The effect of school on overweight in childhood: gain in body mass index during the school year and during summer vacation. Am J Public Health, 97(4), 696-702.

Wang Y., Wu Y., Wilson R. F., Bleich S., Cheskin L., Weston C., ... Segal J. (2013). Childhood Obesity Prevention Programs: Comparative Effectiveness Review and Meta-Analysis. Agency for Healthcare Research and Quality.

WHO. (2017). Obesity and overweight. Available at http://www.who.int/mediacentre/factsheets/fs311/en/. Accessed 10 November 2017.

WHO. (2017). Growth reference 5-19 years. http://www.who.int/growthref/tools/en/. Accessed April 5, 2017. 


\section{CHAPTER VII: SUMMARY AND CONCLUSIONS}

\section{Discussion of hypotheses}

\section{The effect of "My Healthy Habits" summer camp on improving the participant's nutrition knowledge and behavior}

Our study showed that an 8-week summer camp intervention led to a significant increase in nutrition knowledge of children aged 6-10 years old by providing nutrition education sessions following CATCH Kids Club curriculum 2 times per week for 8 weeks. The intervention also resulted in an increase in the consumption of healthy foods including fruits, vegetables, dairy, whole grains, and lean proteins. It resulted in significant decrease in the consumption of sweets and candies in the intervention group, but no effect was seen for fries and sugary drinks.

Overall, hypothesis $1 \mathrm{a}$ and $\mathrm{b}$ were supported in this intervention that it is effective in improving nutrition knowledge and behavior by adding more servings of healthy food to their diet including fruits, vegetables, dairy, wholegrains, and lean proteins. Hypothesis c was partially supported in consumption of fewer servings of sweets and candies but not fries, and sugary drinks.

\section{The effect of My Healthy Habits summer camp on improving the participant's physical activity level and screen time \\ Results showed that an 8-week summer camp significantly increased time spent on physical activity by the participants for 1 hour 5-7 days a week. Significantly reduced screen time to the recommended for no more than 2 hours per day. Significantly}


increased participants knowledge regarding the recommended time spend on screen or physical activity and the benefits of physical activities.

Overall, hypothesis $2 \mathrm{a}, \mathrm{b}, \mathrm{c}$, and d were supported by this intervention. It was effective in increasing participants' knowledge related to physical activities and screen time. The intervention was effective in increasing time spent on physical activities to 1 hour 5-7 days a week and decreasing time spent on the screen to less than 2 hours per day.

The effect of My Healthy Habits summer camp on the weight percentile and waistto-height ratio.

Our findings showed that an 8-week nutrition education and physical activity summer camp lead to significant reduction in participants' weight, BMI, waist circumference, and WHtR. However, there was no effect of age or gender on BMI reduction in this study.

Overall, hypothesis $3 \mathrm{a}$ and $\mathrm{b}$ were supported in this intervention by having less WHtR and BMI percentile after the intervention. 


\section{CHAPTER VIII: STRENGTHS AND LIMITATIONS}

Strengths of this study include that this was the first study conducted in Kuwait for nutrition education intervention. The groups were randomly assigned to intervention or comparison group, and there were no significant differences between the two groups in regard to sociodemographic status, baseline BMI categories, or WHtR. Low dropout rate by only two participants from the intervention group due to attending less than $80 \%$ of the classes.

Study limitation includes, desired sample size of 140 participants was not met, and only 79 participated due to long follow-up period and people in Kuwait tend to travel during summer break. There was a significant difference in the mothers' BMI between groups. The comparison group had significantly more overweight mothers than the intervention group which had more normal weight mothers, and that might have affected the comparability of the results. This study also is lacking long-term follow-up to observe if the results are sustainable. 


\section{CHAPTER IX: FUTURE RESEARCH}

Introducing nutrition education to Kuwaiti children is an area that needs to be studied. An 8-week summer camp showed promising results in increasing children's knowledge regarding nutrition, physical activity and screen time. It showed promising results regarding improving participants behavior related to healthy foods, physical activities, and screen time. This intervention also showed reduction in participants BMI percentile and WHtR.

Future research need to explore the effect of children's nutrition education and physical activities on a larger sample size, and longer follow up to determine the sustainability of these results. Future research my also consider having nutrition education and physical activities as extra curriculum activities during school year. 
Appendix 1: Intervention group Recruitment flyers 

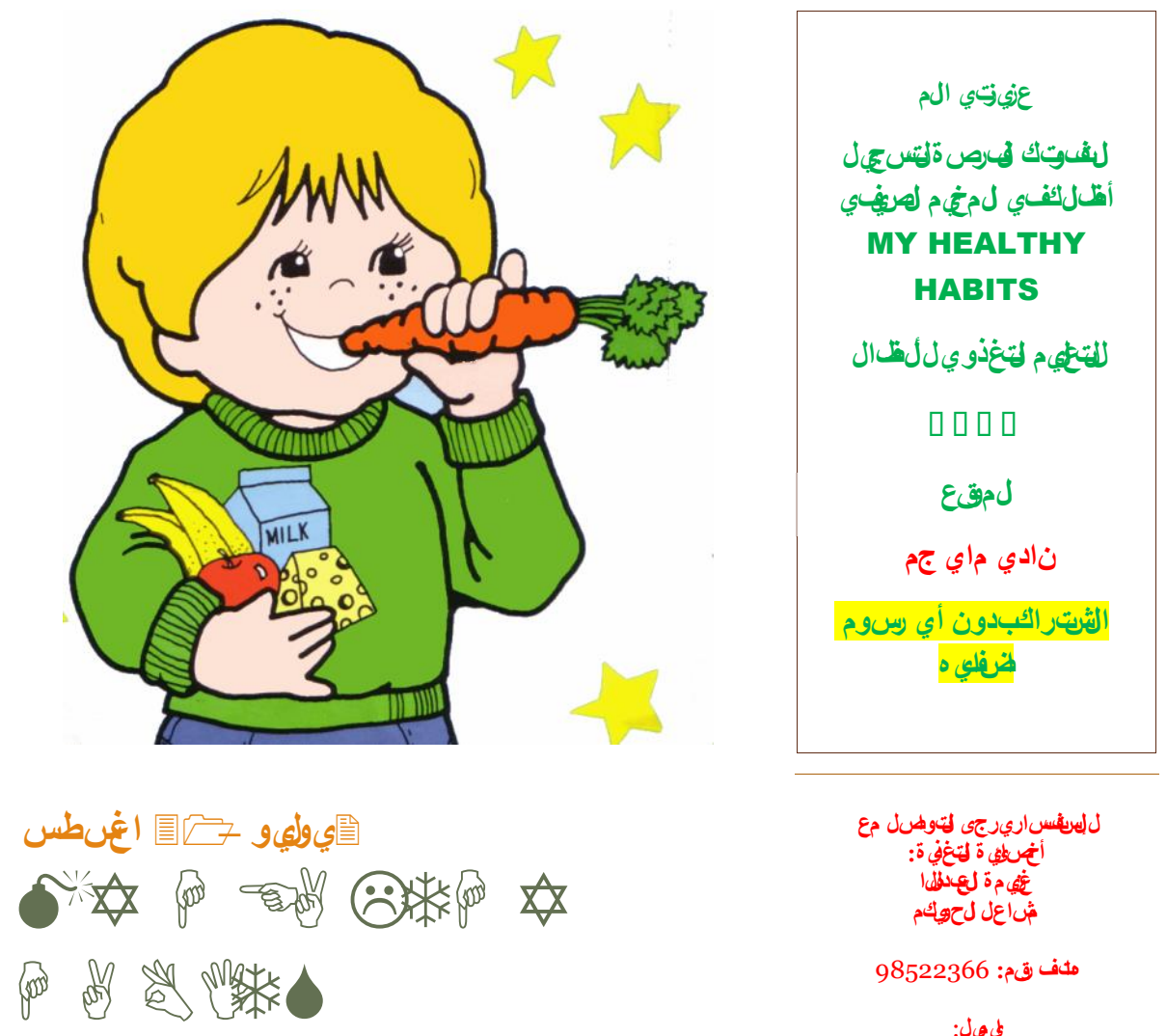

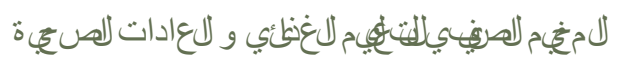

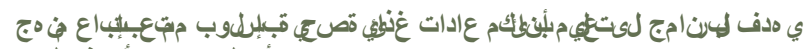

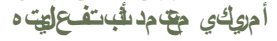
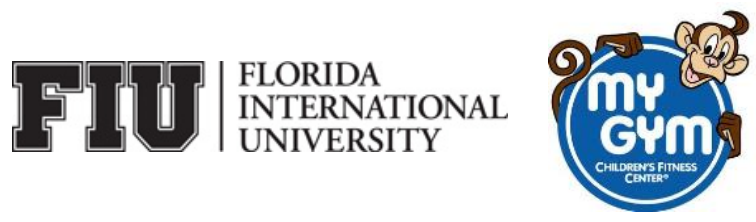

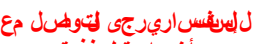

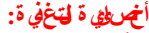

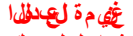

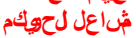

ملف تقم:

$$
\text { : }
$$

galaboo1@fiu.edu

mhuwaoo1@fiu.edu

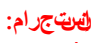

@ask_ur_nutritionist

$$
\begin{aligned}
& \text { نادي ماي جمجلاويلض يلِ لفظال }
\end{aligned}
$$

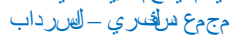

$$
\begin{aligned}
& \text { ثلهل الن بغنى } 99114373
\end{aligned}
$$

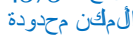




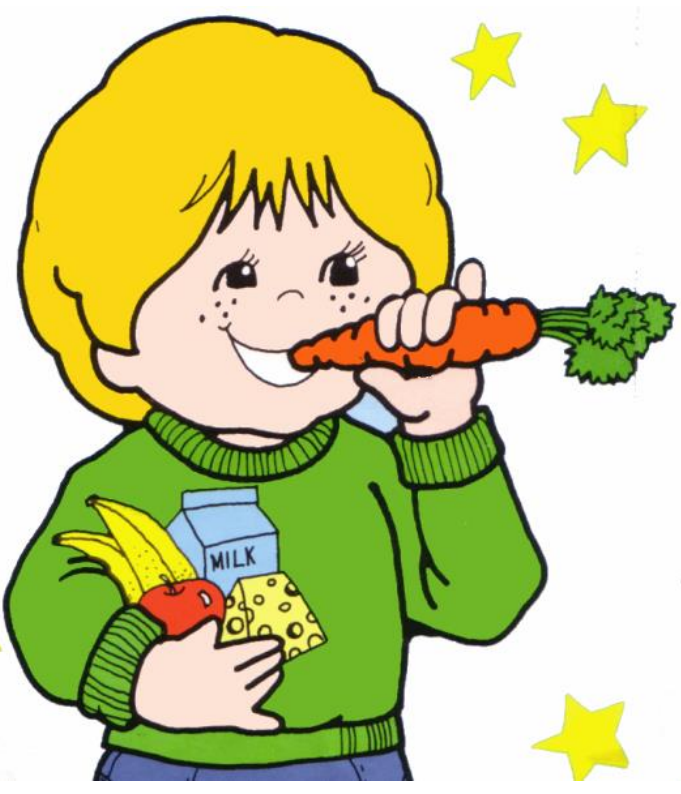

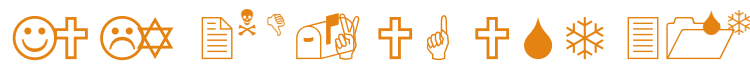

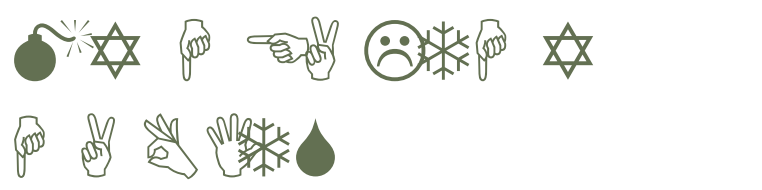

Nutrition Education \& Physical Activity

MY HEALTHY HABIT is a summer camp focusing on promoting Healthy Eating Habits and Physical Activities among children.

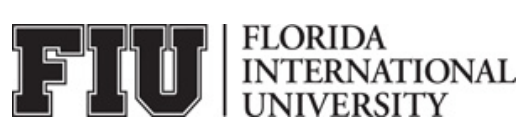

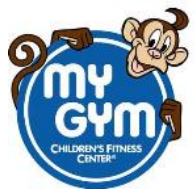

\section{Dear mom}

(1) 0 O opportunity to let your child to be part of the MY HEALTHY HABITS nutrition education \&. physical activity summer camp

प्र००

The classes will take place in

\section{My Gym}

No extra charges are required

Ghanima Alabdullah

Mashael Huwaikem

Contact \#: 98522366 e-mail:

galaboo1@fiu.edu mhuwaoo1@fiu.edu Instagram:

@ask_ur_nutritionist

My Gym children's fitness center

Discovery mall - Basement

Call now 99114373

Seats are limited

Instagram: @mygymkuwait

www.mygym.com/kuwaitcity 
Appendix 2: Control group Recruitment flyers 


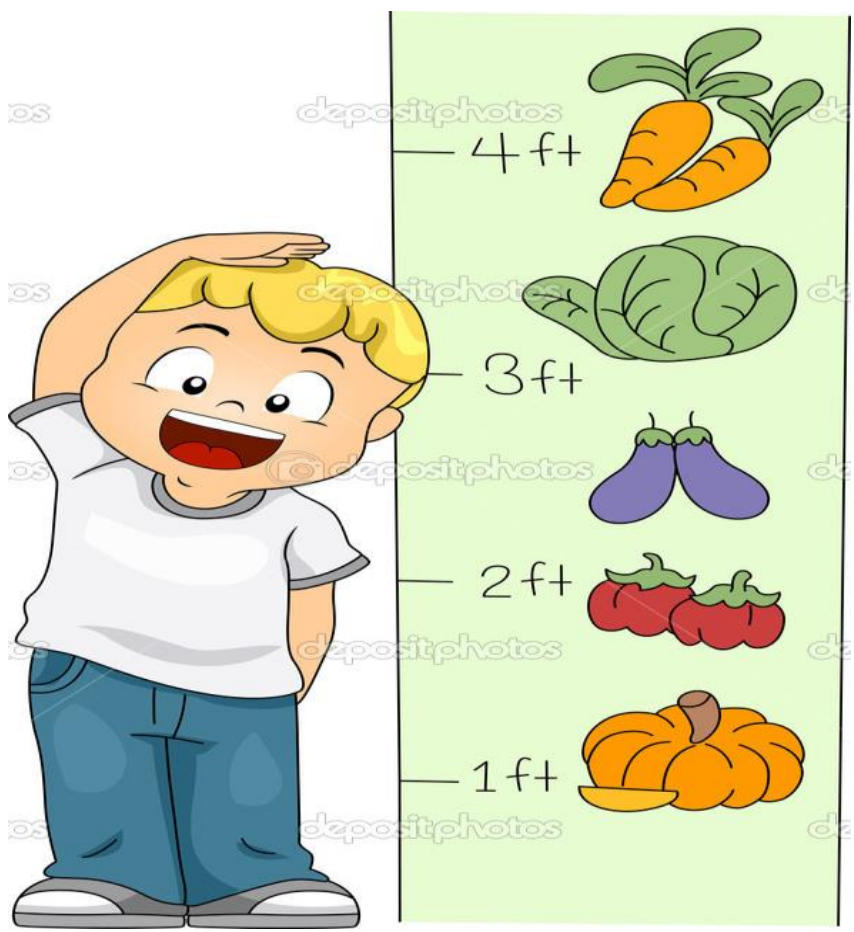

2JULY - 31AUGIST

\section{WHEN IS THE LAST TIME YOU MEASURED YOUR CHILD'S BMI?}

In cooperation with The Little Gym, children's measurements will be taken for FREE by nutritionists to identify the child's weight and nutritional information.

- The measurements will be taken in two stages: the beginning of July and the end of August.

- What's my Benefit?

Identify your child's BMI.

Receive a free child nutrition workshop when taking initial and final measurements.

\section{FIU]}

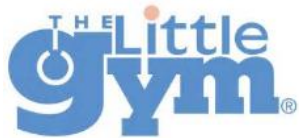

Dear parent, if your child aged between 6-

10 years old and you wish to know his/her

BMI and body composition,

Participate in our study.

\section{Location}

The Little Gym

Hurry up participants

are limited

To register contact

dietitian

Ghanima Alabdullah

Mashael Huwaikem

Phone\#:9852236

Email:

galaboo@fiu.edu

mhuwa0o1@fiu.ed

Instagram:

@ask_ur_nutritionist

Child's name:

Attendance period:

Morning / Afternoon

Parent contact number: 


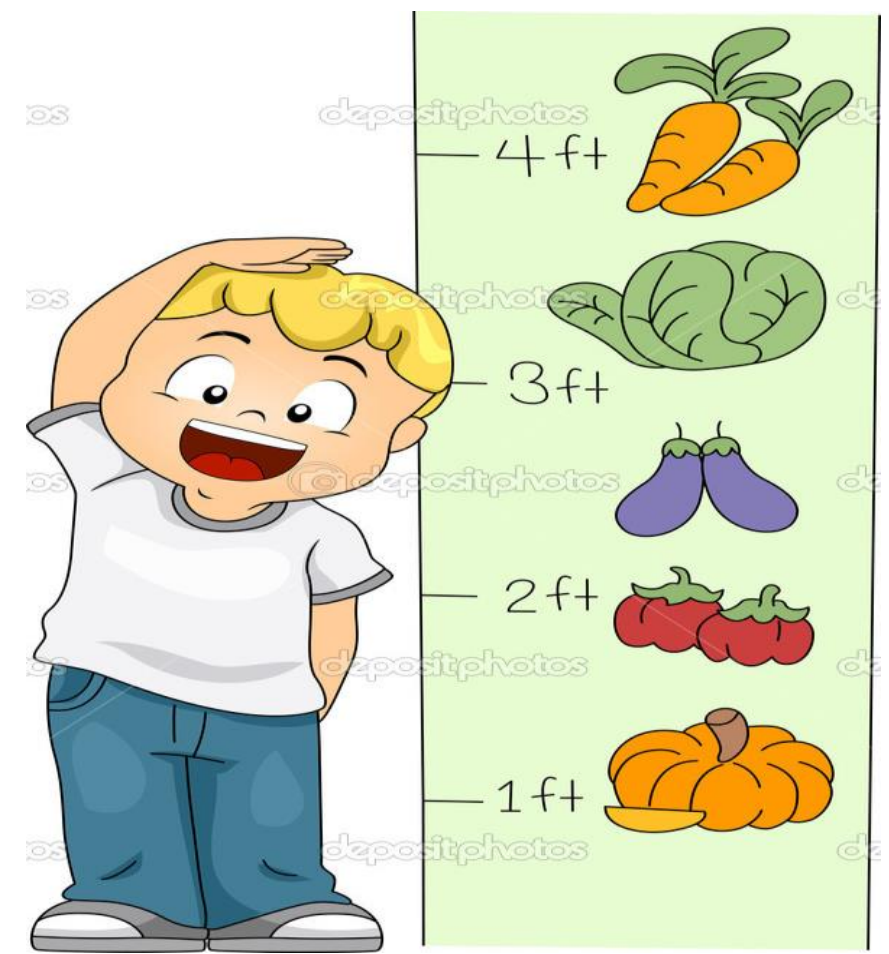

2 يوليو - 31 اغشطس

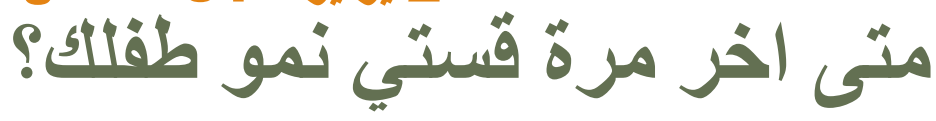

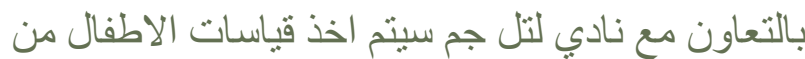
قبل اخصائيات تغذيه للتعرف على نسبة وزئ نائ الطفل و معلوماته الغذائيه.

سيتم اخذ القياسات على مرحلتين: بداية شهر يوليو و نهاية شهر<smiles>C1CC[As]CC1</smiles>

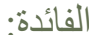

$$
\text { م التعرف على نسبة وزن الطفل بالنسبة لطولة. }
$$

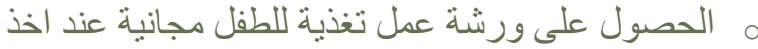

$$
\text { القياسات المبدئية و النهائية. }
$$

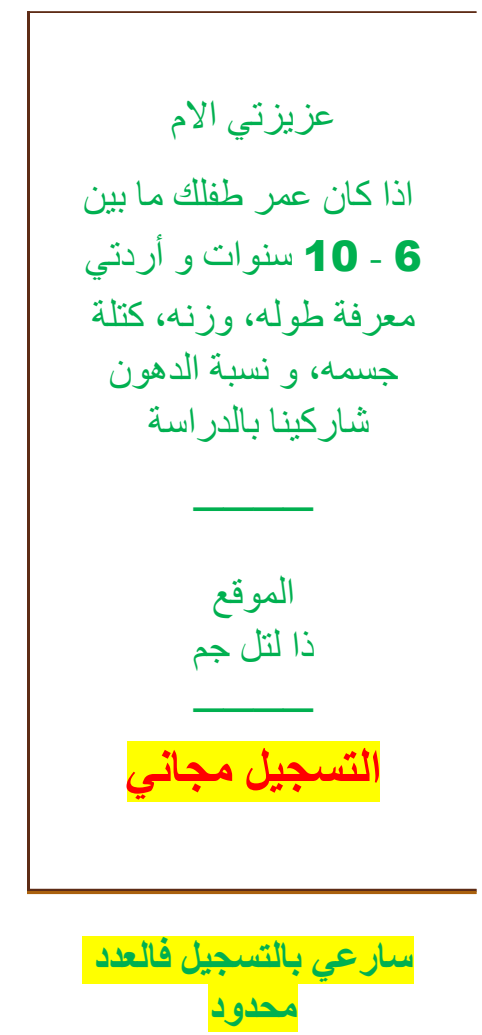

ل للاشتر الك يرجى التو اصل مع إن أخصائية التغذية:

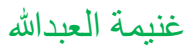
مشاعل الحويكم هاتف رقم:

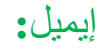

galaboo1@fiu.edu mhuwa001@fiu.ed

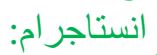

@ask_ur_nutritionist

$$
\text { رقباحا لبعد الظهر : رقم هاتف ولي الامر: }
$$


Appendix 3: IRB approved Consent/Assent Forms

\begin{tabular}{|l|l|}
\hline FIU IRB Approval: & $6 / 14 / 2017$ \\
\hline FIU IRB Expiration: & $6 / 14 / 2018$ \\
\hline FIU IRB Number: & IRB-17-0197 \\
\hline
\end{tabular}




\begin{tabular}{|l|l|}
\hline FIU IRB Approval: & $6 / 14 / 2017$ \\
\hline FIU IRB Expiration: & $6 / 14 / 2018$ \\
\hline FIU IRB Number: & IRB-17-0197 \\
\hline
\end{tabular}

\section{FIU] UNIVERSITY}

\section{CHILD ASSENT TO PARTICIPATE IN A RESEARCH STUDY \\ Promoting healthy eating habits and physical activities among children in Kuwait during summer break.}

\section{WHY ARE YOU DOING THIS STUDY?}

We would like for you to be in a research study we are doing. A research study is a way to learn information about something. We would like to find out more about the effectiveness of eightweek summer camp to reduce overweight and obesity, and promote Healthy Eating Habits and Physical Activities among children in Kuwait.

\section{HOW MANY OTHERS WILL BE IN THIS STUDY?}

If you agree to participate in this study, you will be one of 140 children in this research study.

\section{HOW LONG WILL THE STUDY LAST?}

Your participation will require an hour/day, 2 days a week, for 2 months.

\section{WHAT WILL HAPPEN IN THIS STUDY?}

If you go to The Little Gym summer camp, you will:

1. Answer a questionnaire related to eating habits, physical activities, and screen time before and after the intervention.

2. Take your height, weight, waist circumference, fat mass and fat free mass.

3. Provide photographic food record for three days before and after the intervention.

If you go to My Gym Kuwait summer camp, you will:

1. Answer a questionnaire related to eating habits, physical activities, and screen time before and after the intervention.

2. Take your height, weight, waist circumference, fat mass and fat free mass.

3. Provide photographic food record for three days before and after the intervention.

4. Participate in nutrition education classes (hour/day, 2 days a week, for 2 months).

5. You will do some walking and stretching exercises 40-60 minutes, 3-4 times a week.

\section{CAN ANYTHING BAD HAPPEN TO ME?}

You may be tired or sore from the extra walking and stretching, but you will have time to rest and given water to drink.

\section{CAN ANYTHING GOOD HAPPEN TO ME?}

The following benefits may be associated with your participation in this study: learning healthy eating habits and participating in physical activity classes.

\section{DO I HAVE OTHER CHOICES?}

There are no known alternatives available to you other than not taking part in this study. 


\begin{tabular}{|l|l|}
\hline FIU IRB Approval: & $6 / 14 / 2017$ \\
\hline FIU IRB Expiration: & $6 / 14 / 2018$ \\
\hline FIU IRB Number: & IRB-17-0197 \\
\hline
\end{tabular}

\section{WILL ANYONE KNOW I AM IN THE STUDY?}

The records of this study will be kept private and will be protected by the researchers.

\section{WILL I BE GIVEN ANYTHING FOR PARTICIPATING?}

If you are attending My Gym Kuwait, you will receive a toy from the treasure box for winning a game, answering a question, or for other activities. You will also receive a two free weeks gift card for perfect attendance and providing the required worksheets. You will not be responsible for any costs to participate in this study.

If you are attending The Little Gym, you will receive a toy from the treasure box for answering a questionnaire and taking your measurements. At the end of the study, you will receive a gift for participation. You also will learn healthy eating habits and get some healthy exercise.

\section{WHAT IF I DO NOT WANT TO DO THIS?}

You do not have to be in this study if you don't want to and you can quit the study at any time. If you don't like a question, you don't have to answer it and, if you ask, your answers will not be used in the study. No one will get mad at you if you decide you don't want to participate.

\section{WHO CAN I TALK TO ABOUT THE STUDY?}

If you have any questions about the research study you may contact Ghanima Alabdullah at Nutrition and Food Administration, 98522366, galab001@fiu.edu or Mashael Huwaikem, Mhuwa001@fiu.edu. If you would like to talk with someone about your rights of being a participant in this research study, you may contact the FIU Office of Research Integrity by phone at 305-348-2494 or by email at ori@ fiu.edu.

PARTICIPANT AGREEMENT

This research study has been explained to me and I agree to be in this study.

Signature of Child Participant

Printed Name of Child Participant

Signature of Person Obtaining Consent
Date

$\overline{\text { Date }}$ 


\begin{tabular}{|l|l|}
\hline FIU IRB Approval: & $6 / 14 / 2017$ \\
\hline FIU IRB Expiration: & $6 / 14 / 2018$ \\
\hline FIU IRB Number: & IRB-17-0197 \\
\hline
\end{tabular}

\section{FLORIDA
INTERNATIONAL
UNIVERSITY}

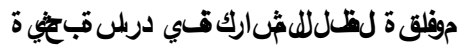

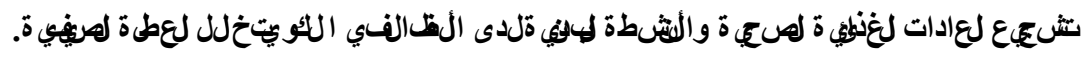

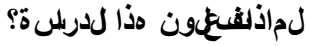

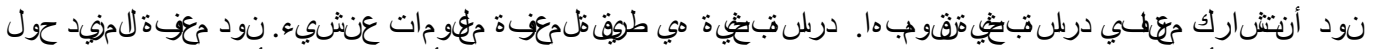

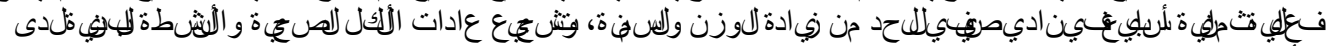

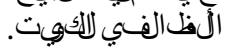

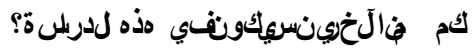

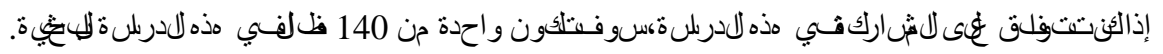

$$
\begin{aligned}
& \text { كهتستغنق لدربلسة }
\end{aligned}
$$

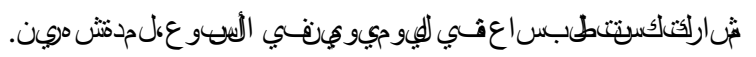

$$
\begin{aligned}
& \text { ماذاسيرحدثفي دذه لدربلة؛ }
\end{aligned}
$$

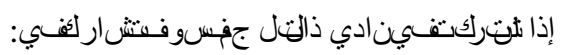

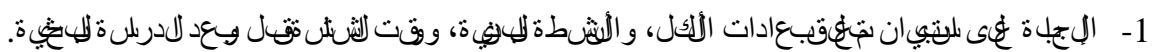

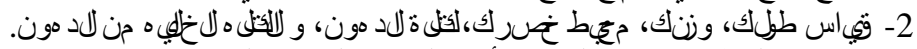

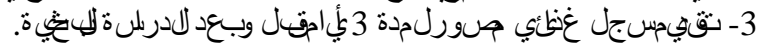

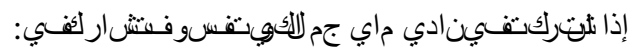

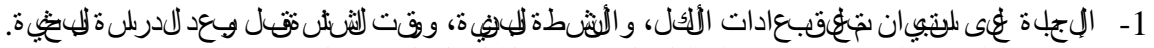

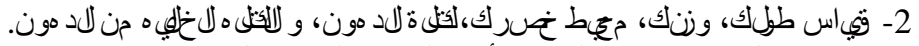

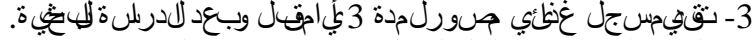

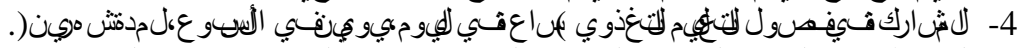

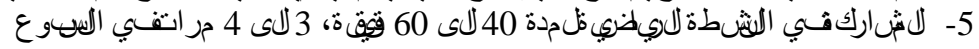

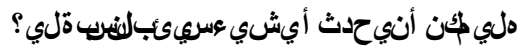

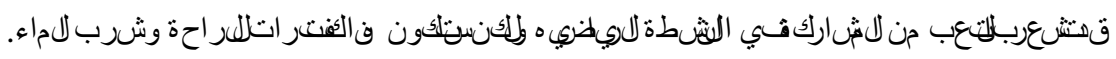

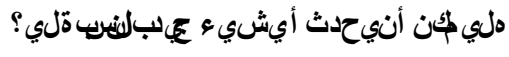

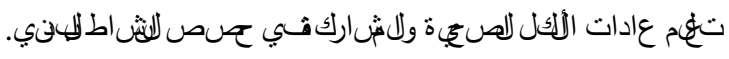




\begin{tabular}{|l|l|}
\hline FIU IRB Approval: & $6 / 14 / 2017$ \\
\hline FIU IRB Expiration: & $6 / 14 / 2018$ \\
\hline FIU IRB Number: & IRB-17-0197 \\
\hline
\end{tabular}

$$
\text { هلدي غُ ارات أخرى؟ }
$$

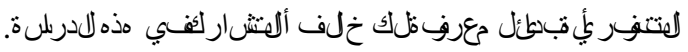

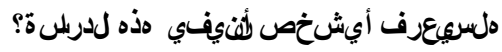

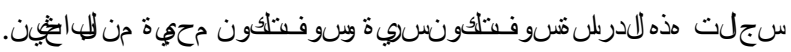

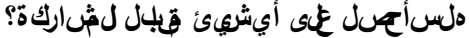

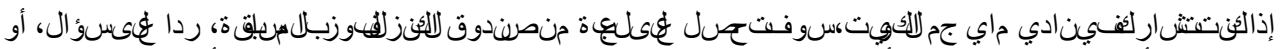

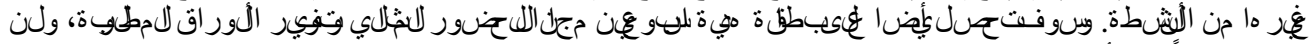

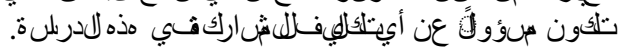

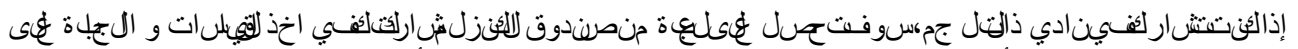

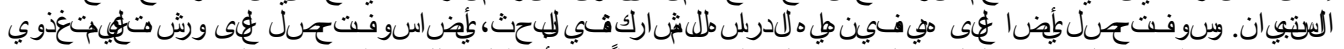

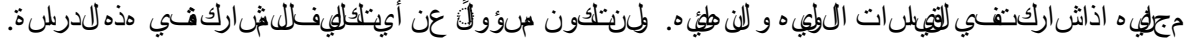

ما إذالثيت ل أبيد لقي امبلىك؟

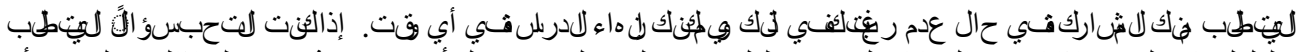

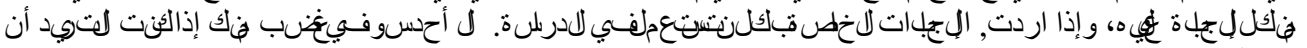

$$
\text { نشارك }
$$

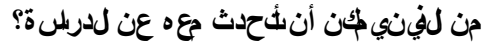

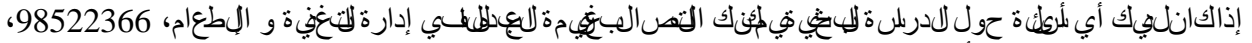

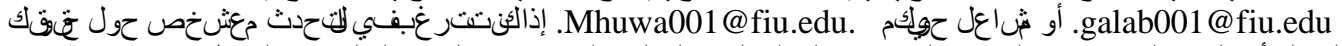

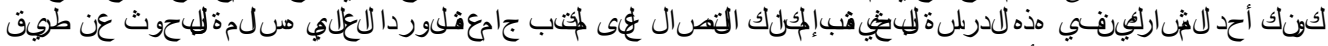

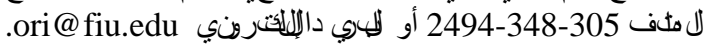

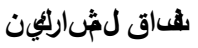

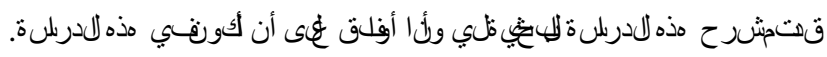

للثاويخ

ت توفئع للفل لاثنارك

$$
\text { لسم لافل للثمارك }
$$

توتي للثن خص لاذيي حسل عهى مذه للموفقة 


\begin{tabular}{|l|l|}
\hline FIU IRB Approval: & $6 / 14 / 2017$ \\
\hline FIU IRB Expiration: & $6 / 14 / 2018$ \\
\hline FIU IRB Number: & IRB-17-0197 \\
\hline
\end{tabular}

\section{FIU]}

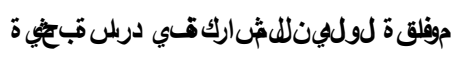

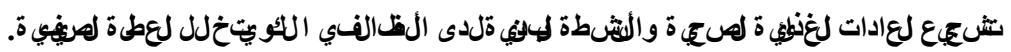

\section{لغزرض من لدربلة}

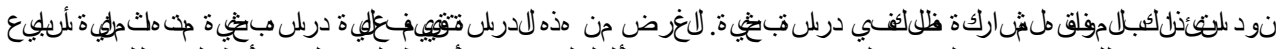

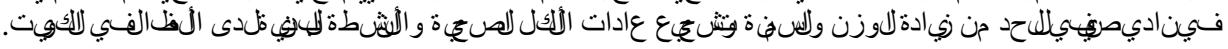

\section{عدد من لثمارلئنهي لدربلة}

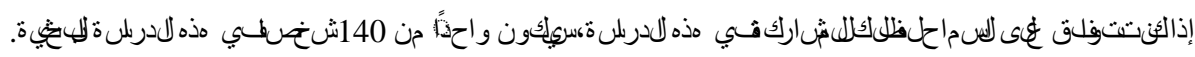

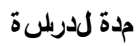

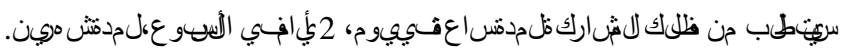

إجراءات إنرات

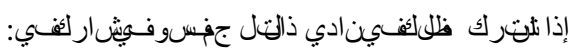

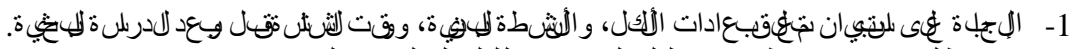

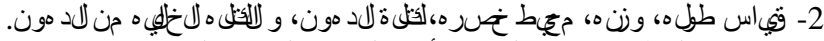

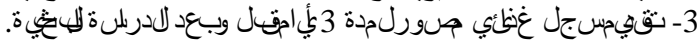

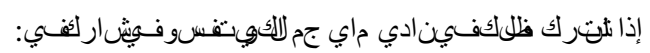

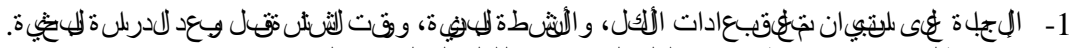

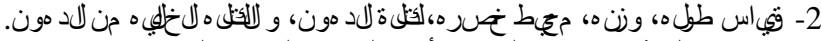

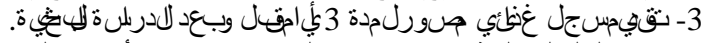

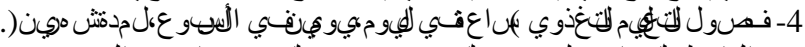

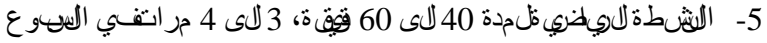

لجخاطر و/أو لخيقةتات

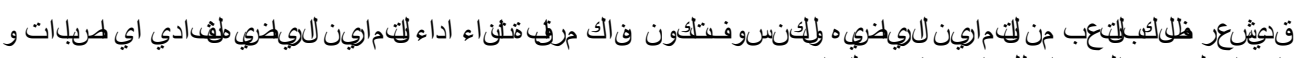

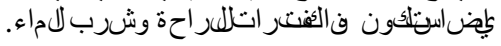




\begin{tabular}{|l|l|}
\hline FIU IRB Approval: & $6 / 14 / 2017$ \\
\hline FIU IRB Expiration: & $6 / 14 / 2018$ \\
\hline FIU IRB Number: & IRB-17-0197 \\
\hline
\end{tabular}

فـوئد

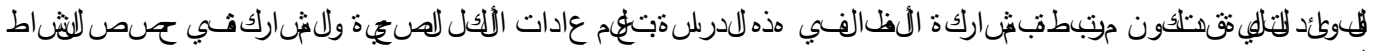
للانفي.

له

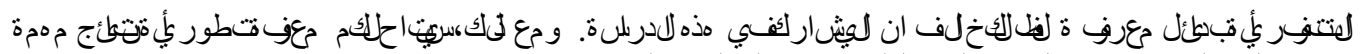

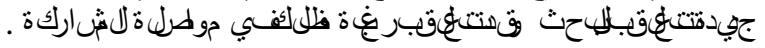

لسنية

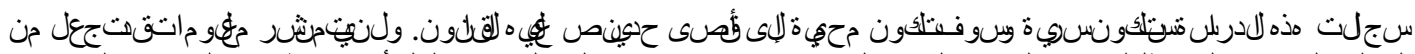

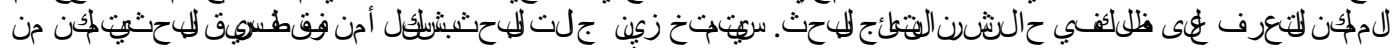

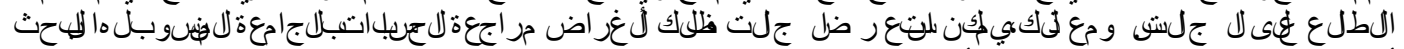

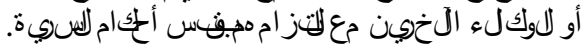

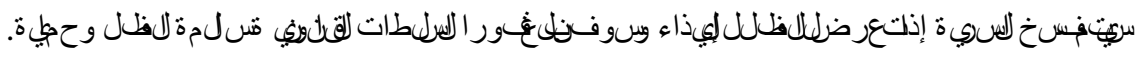

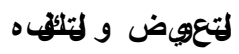

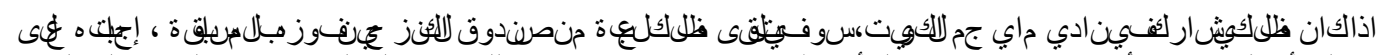

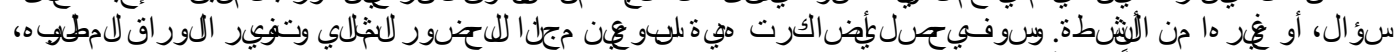

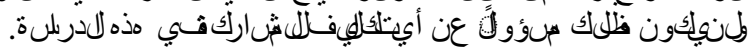

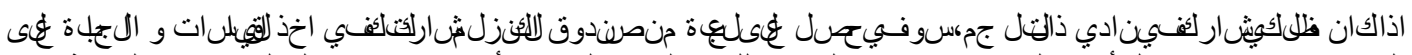

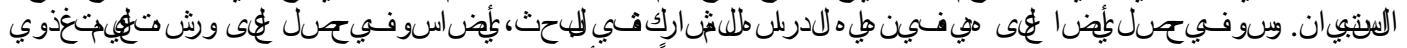

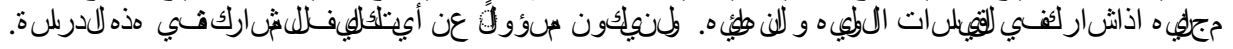

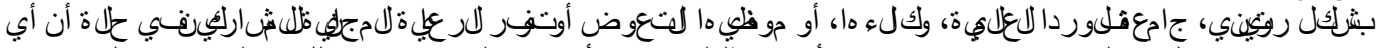

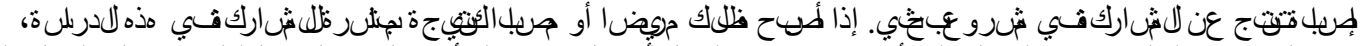

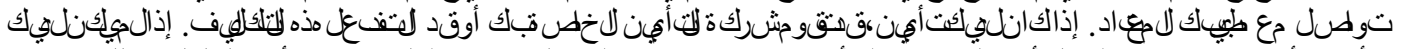

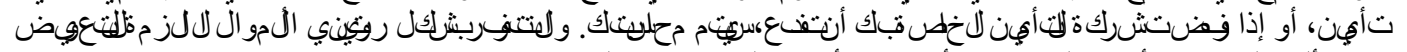

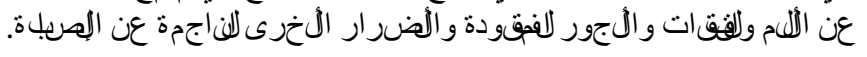

ل احقفي فض أوسحب

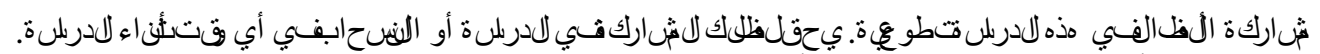

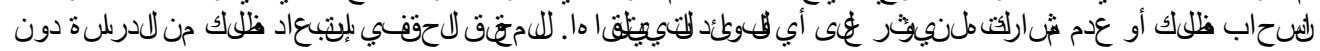

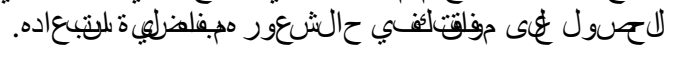

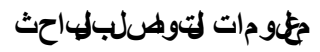


\begin{tabular}{|l|l|}
\hline FIU IRB Approval: & $6 / 14 / 2017$ \\
\hline
\end{tabular}

FIU IRB Expiration: $6 / 14 / 2018$

FIU IRB Number:

IRB-17-0197

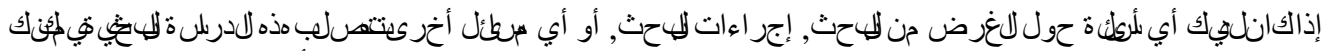

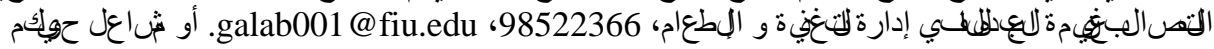
Mhuwa001@fiu.edu.

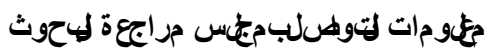

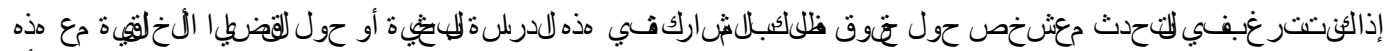

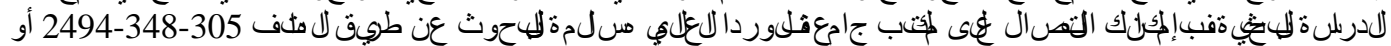

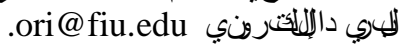

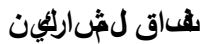

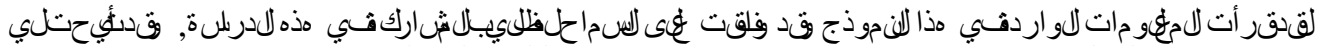

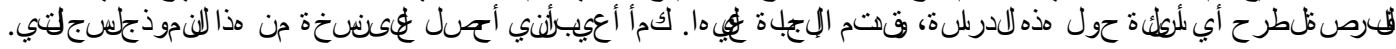

للثاريخ

توفيع لطي الامر أو للوصي للثندعي

$\overline{-(n+30}$

غ

لسم ولي اللمر أو للموصي للثرعي

لسم للفل لاثشارك

لثاروبخ

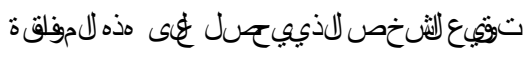




\begin{tabular}{|l|l|}
\hline FIU IRB Approval: & $6 / 14 / 2017$ \\
\hline FIU IRB Expiration: & $6 / 14 / 2018$ \\
\hline FIU IRB Number: & IRB-17-0197 \\
\hline
\end{tabular}

\title{
FLORIDA
INTERNATIONAL
UNIVERSITY
}

\author{
PARENTAL CONSENT TO PARTICIPATE IN A RESEARCH STUDY \\ Promoting healthy eating habits and physical activities among children in Kuwait during \\ summer break.
}

\section{PURPOSE OF THE STUDY}

You are being asked to give your permission for your child to be in a research study. The purpose of this study is to assess the effectiveness of eight-week intervention at a summer camp to reduce overweight and obesity, and promote Healthy Eating Habits and Physical Activities among children in Kuwait.

\section{NUMBER OF STUDY PARTICIPANTS}

If you agree to allow your child to participate in this study, he/she will be one of 140 people in this research study.

\section{DURATION OF THE STUDY}

Your child's participation will require an hour/day, 2 days a week, for 2 months.

\section{PROCEDURES}

If your child goes to The Little Gym summer camp, he/she will:

1. Answer a questionnaire related to eating habits, physical activities, and screen time before and after the intervention.

2. Take his/her height, weight, waist circumference, fat mass and fat free mass.

3. Provide photographic food record for three before and after the intervention.

If your child goes to My Gym Kuwait summer camp, he/she will:

1. Answer a questionnaire related to eating habits, physical activities, and screen time before and after the intervention.

2. Take his/her height, weight, waist circumference, fat mass and fat free mass.

3. Provide photographic food record for three days before and after the intervention.

4. Participate in nutrition education classes (hour/day, 2 days a week, for 2 months).

5. Your child will have some additional walking and stretching exercises 40-60 minutes, 3-4 times a week.

\section{RISKS AND/OR DISCOMFORTS}

Your child may become tired, sore, or thirsty from the extra walking and stretching. However, he/she will be closely supervised, and he/she will be given time to rest and water to drink as necessary"

\section{BENEFITS}

The following benefits may be associated with your child's participation in this study: learning healthy eating habits and participating in physical activity classes. 


\begin{tabular}{|l|l|}
\hline FIU IRB Approval: & $6 / 14 / 2017$ \\
\hline FIU IRB Expiration: & $6 / 14 / 2018$ \\
\hline FIU IRB Number: & IRB-17-0197 \\
\hline
\end{tabular}

\begin{abstract}
ALTERNATIVES
There are no known alternatives available to your child other than not taking part in this study. However, any significant new findings developed during the course of the research which may relate to your child's willingness to continue participation will be provided to you.

CONFIDENTIALITY

The records of this study will be kept private and will be protected to the fullest extent provided by law. In any sort of report we might publish, we will not include any information that will make it possible to identify your child as a subject. Research records will be stored securely and only the researcher team will have access to the records. However, your child's records may be reviewed for audit purposes by authorized University or other agents who will be bound by the same provisions of confidentiality.

Confidentiality will be broken if the child is being abused and we will immediately inform legal authorities for child safety and protection.
\end{abstract}

\title{
COMPENSATION \& COSTS
}

If your child is attending My Gym Kuwait, he/she will receive a toy from the treasure box for winning a game, answering a question, or for other activities. He/she will also receive a two weeks gift card for perfect attendance and bringing back the required paperwork. Your child will not be responsible for any costs to participate in this study.

If your child is attending The Little Gym, he/she will receive a toy from the treasure box for taking his/her measurements and answering a questionnaire. At the end of the study, your child will receive a gift for participation and a nutrition education session if he/she participate in the initial and end measurements. Your child will not be responsible for any costs to participate in this study.

\section{MEDICAL TREATMENT}

Routinely, FIU, its agents, or its employees do not compensate for or provide free care for human subjects in the event that any injury results from participation in a research project. If your child becomes ill or injured as a direct result of participating in this study, contact your regular medical provider. If you have insurance, your insurance company may or may not pay for these costs. If you do not have insurance, or if your insurance company refuses to pay, you will be billed. Funds to compensate for pain, expenses, lost wages and other damages caused by injury are not routinely available.

\section{RIGHT TO DECLINE OR WITHDRAW}

Your child's participation in this study is voluntary. Your child is free to participate in the study or withdraw his/her consent at any time during the study. Your child's withdrawal or lack of participation will not affect any benefits to which he/she is otherwise entitled. The investigators reserves the right to remove your child from the study without your consent at such time that they feel it is in the best interest.

\section{RESEARCHER CONTACT INFORMATION}

If you have any questions about the purpose, procedures, or any other issues relating to this research study you may contact Ghanima Alabdullah at Nutrition and Food Administration, 98522366, galab001@fiu.edu or Mashael Huwaikem, Mhuwa001@ fiu.edu. 


\begin{tabular}{|l|l|}
\hline FIU IRB Approval: & $6 / 14 / 2017$ \\
\hline FIU IRB Expiration: & $6 / 14 / 2018$ \\
\hline FIU IRB Number: & IRB-17-0197 \\
\hline
\end{tabular}

\section{IRB CONTACT INFORMATION}

If you would like to talk with someone about your child's rights of being a subject in this research study or about ethical issues with this research study, you may contact the FIU Office of Research Integrity by phone at 305-348-2494 or by email at ori@ fiu.edu.

\section{PARTICIPANT AGREEMENT}

I have read the information in this consent form and agree to allow my child to participate in this study. I have had a chance to ask any questions I have about this study, and they have been answered for me. I understand that I will be given a copy of this form for my records.

Signature of Parent/Guardian

Printed Name of Parent/ Guardian

Printed Name of Child Participant

$\overline{\text { Signature of Person Obtaining Consent }}$
Date

Date 
Appendix 4: Socio-demographic questionnaire 


\section{الخصائص الاجتماعية و الايموغرافية}

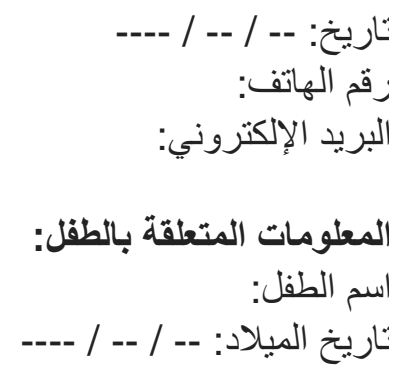

الجنسية:

口 الكويتية الجنية

口 غير الكويتية

الجنس:

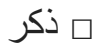

口 أنثى

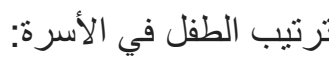

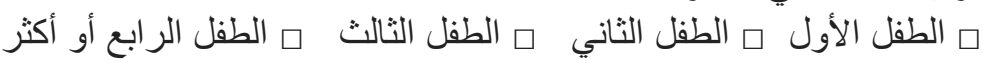

هل يعاني طفلك من أي مرض مزمن أو إعاقة جسدية أو متلازمة؟ اذا كانت الاجابة نعم الرجاء ذكرها

$\gamma$

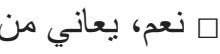

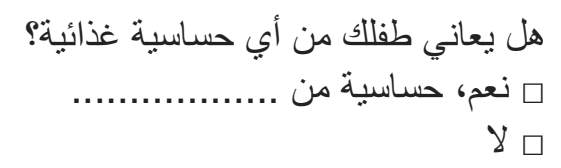

هل شارك طفلك في أي دورة لتعليم التغذية؟ إذا كانت الإجابة نعم، ما هو اسم الدورة ، تاريخها ، و مدتها.

اسم الدوره:

كيف تصنف وزن طفلك؟ بإن

口 لديه نقص بالوزن

口 طبيعي لإنه

口 لديه زيادة بالوزن

口 إمين

إذا كانت الطفلة المشاركة فتاة، هل بدأت دورنها الثهريه؟ إذا كان الجواب نعم منذ منى؟

口 نعم، منذ متى لـ........... 


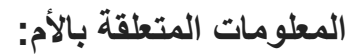

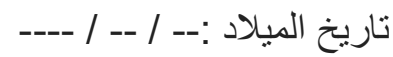

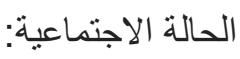

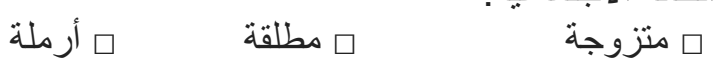

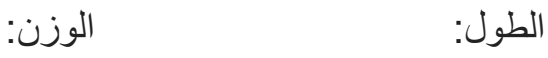

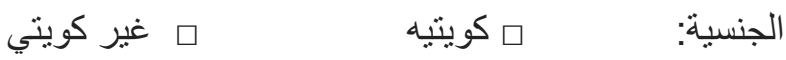

$$
\begin{aligned}
& \text { عدد الأطفال: }
\end{aligned}
$$

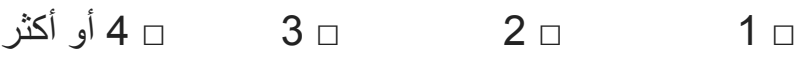

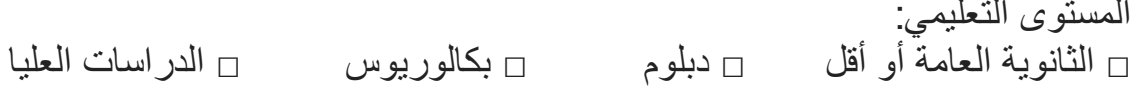

$$
\begin{aligned}
& \text { حالة العمل: } \\
& \text { إجمالي دخل الأسرة: }
\end{aligned}
$$

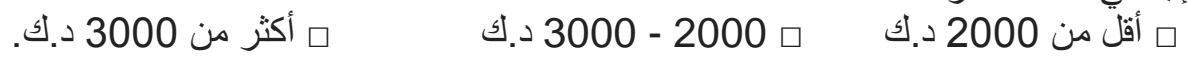

$$
\begin{aligned}
& \text { هل لديك مربية؟ } \\
& \text { 口 ن لانع } \\
& \text { Y } \square \\
& \text { هل شاركت في أي دورة لتعليم التغذية؟ إذا كانت الإجابة نعم، ما هو اسم الدورة ، تاريخها ، و مدتها. }
\end{aligned}
$$

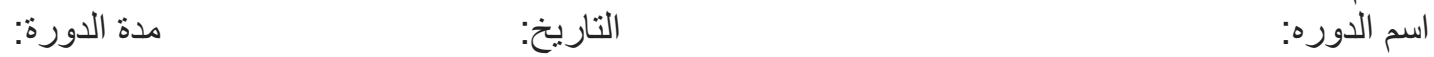




\section{Sociodemographic Characteristics}

Date: -- / -- / ----

Phone number:

E-mail:

\section{INFORMATION RELATED TO THE CHILD:}

Child's name:

Date of birth: -- / -- / ----

Nationality:

Kuwaiti

$\square$ Non-Kuwaiti

Gender:

$\square$ Male

$\square \quad$ Female

Rank in the family:
First child
$\square$ Second child
$\square$ Third child
$\square$ Forth child or more

Does your child suffer from any chronic disease, physical disability, or syndrome? If yes please mention

$\square$ Yes, suffering from $\ldots \ldots \ldots \ldots \ldots \ldots \ldots \ldots \ldots \ldots \ldots \ldots \ldots$

Does your child suffer from any food allergy?

$\square$ Yes, allergic to

$\square$ No

Did your child participate in any nutrition education classes? If yes provide name of the course, date, and duration.

$\square$ Yes $\quad \square \mathrm{NO}$

Name:

Date:

Length:

How do you categorize the child weight?
Underweight
Normal
$\square$ Overweight
$\square$ Obese

If you child is a girl, did she start her period? If yes since when?

$\square$ Yes, Since when.......... $\quad \square \quad$ No 


\section{INFORMATION RELATED TO THE MOTHER:}

Date of birth: -- / -- / ----

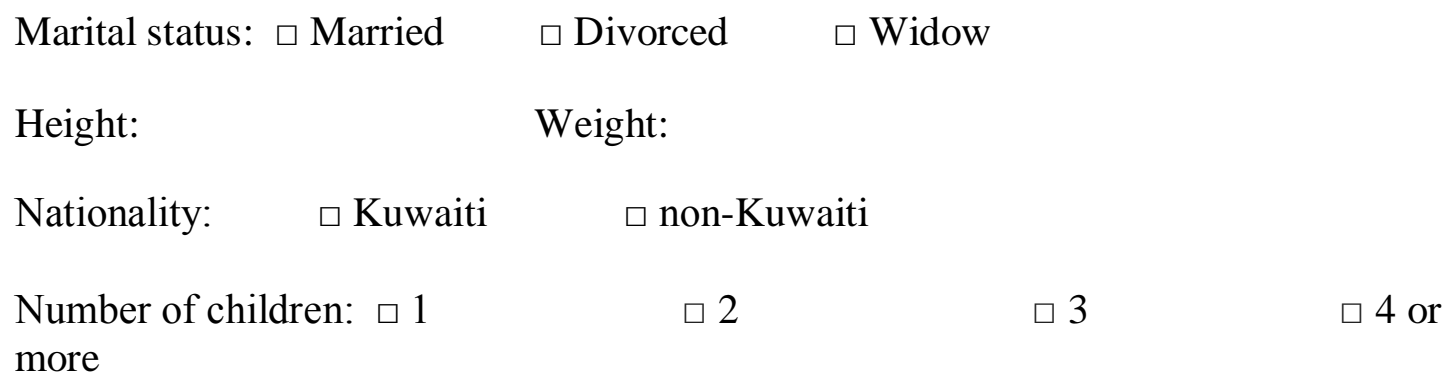

Educational level:

High school or below $\quad \square 2$ year diploma $\square$ Bachelor degree
Postgraduate

Working status: $\square$ Working $\square$ Housewife

Total family income: $\quad \square<2000 \mathrm{KD} \quad \square 2000-3000 \mathrm{KD} \quad \square>3000$

KD

Do you have a nanny? $\square$ Yes $\square$ No

Did you participate in any nutrition education classes? If yes provide the name of the course, date, and duration.

$\square$ Yes $\quad \square \mathrm{NO}$

Name:

Date:

Length: 
Appendix 5: Healthy Habits modified survey 


\section{Healthy Habits Survey}

\section{Directions: For the following questions, place an " $x$ " in the ONE box that best} represents your answer. There are no right or wrong answers.

1. Yesterday, how many times did you eat/drink dairy, such as milk, yogurt, or cheese?

$1 \square$ None

$2 \square 1$ time

$3 \square 2$ times

$4 \square 3$ or more times

2. Yesterday, how many times did you eat fresh, frozen, dried or canned fruit? (Do not count fruit juice)
$1 \square$ None
$2 \square 1$ time
$3 \square 2$ times
$4 \square 3$ or more times

3. Yesterday, how many times did you eat fresh, frozen, or canned vegetables? (Do not count French fries or potato chips)
$1 \square$ None
$2 \square 1$ time
$3 \square 2$ times
$4 \square 3$ or more times

4. Yesterday, how many times did you eat French fries or chips? Chips are potato chips, tortilla chips, corn chips, or other snack chips.

4 $\square$ None

3ロ1 time

$2 \square 2$ times

$1 \square 3$ or more times 
5. Yesterday, how many times did you eat whole grains, such as whole grain bread, whole grain tortillas (not corn or white flour tortillas), whole grain pasta, or whole grain crackers?
$1 \square$ None
$2 \square 1$ time
$3 \square 2$ times
$4 \square 3$ or more times

6. Yesterday, how many times did you eat lean protein, such as beef, chicken, fish, beans, peanut butter, eggs, nuts, or seeds? (Do not include fried meat)
$1 \square$ None
$2 \square 1$ time
$3 \square 2$ times
$4 \square 3$ or more times

7. Yesterday, how many times did you drink any punch, sports drinks, or other fruitflavored drinks? (Do not count $100 \%$ juice or diet drinks)

4 $\square$ None

$3 \square 1$ time

$2 \square 2$ times

$1 \square 3$ or more times

8. Yesterday, how many times did you drink any regular (not diet) sodas or soft drinks?
$4 \square$ None
$3 \square 1$ time
$2 \square 2$ times
$1 \square 3$ or more times

9. Yesterday, how many times did you eat doughnuts, cookies, brownies, cakes, or candy?
$4 \square$ None
$3 \square 1$ time
$2 \square 2$ times
$1 \square 3$ or more times

10. How often do you eat breakfast?

$5 \square 7$ days per week

$4 \square$ 5- 6 days per week

$3 \square$ 3-4 days per week

2 $\square$ 1-2 days per week

$1 \square 0$ days per week 
11. How often are you physically active for at least 60 minutes per day or more? (This includes activities such as exercise, sports, running, walking, dancing, etc.)

$5 \square 7$ days per week

$4 \square$ 5-6 days per week

$3 \square$ 3-4 days per week

2 $\square$ 1-2 days per week

$1 \square 0$ days per week

12. How often do you help plan family meals at home?

$5 \square 7$ days per week

$4 \square$ 5-6 days per week

3ロ3-4 days per week

2 $\square$ 1-2 days per week

$1 \square 0$ days per week

directions: For the following questions, place an " $x$ " in the box that represents the ONE answer that you think is correct.

13. It is lunch time and Marty has the following items in her lunch box: an apple, a carton of chocolate milk, yogurt, and grilled chicken. How many different food groups are in Marty's lunch box?

$0 \square 1$

$0 \square 2$

$1 \square 3$

$0 \square 4$

14. Fruits and vegetables are good sources of vitamins. True or false?

1DTrue

0 $\square$ False

15. How many minutes of physical activity do you think you should get each day to be healthy?

$0 \square$ At least 15 minutes each day

$0 \square$ At least 30 minutes each day

$1 \square$ At least 60 minutes each day

$0 \square$ At least 90 minutes each day

16. Why is physical activity good for kids?

$0 \square$ Helps keep you from getting sick 
$0 \square$ Helps you pay attention in school

$0 \square$ Builds healthy bones and muscles to keep you strong

O $\square$ Gives you energy

$1 \square$ All of the above

17. Which food does NOT belong in the grain group?

$0 \square$ Waffle

o $\square$ Noodles

$1 \square$ Peanuts

o $\square$ Oatmeal

18. Which food does NOT belong in the vegetable group?

$0 \square$ Broccoli

$0 \square$ Carrot

$0 \square$ Cabbage

1Pear

19. Which food does NOT belong in the fruit group?

$0 \square$ Strawberries

$1 \square$ Corn

o $\square$ Pineapple

$0 \square$ Watermelon

20. Which food does NOT belong in the protein group?

$0 \square$ Turkey

o $\square$ Chicken

$1 \square$ Potato

0口Beef

21. Which food does NOT belong in the dairy group?

$0 \square$ Cheese

$1 \square$ Cracker

ODPudding

$0 \square$ Yogurt

22. How many total cups of fruit and vegetables combined should you eat each day?

$0 \square$ Less than 2 cups

$0 \square$ At least 2 cups

$0 \square$ At least 3 cups

$1 \square$ At least 4 cups 
23. How many cups should you have from the dairy group each day?
$0 \square 1$ cup
$1 \square 3$ cups
$0 \square 4$ cups
$0 \square 5$ cups

24. An example of a whole grain is:

$1 \square$ Oatmeal

0 $\square$ Tortilla Chips

o $\square$ Animal crackers

$0 \square$ White bread

Directions: For the following questions, place an " $x$ " in ALL boxes that represent ALL answers you think are correct.

25. Which of the following would be a healthy choice for a snack? Check ALL that apply.

$1 \square$ Fruit and yogurt

$0 \square$ Sports drink and cheese puffs

$1 \square$ Whole grain crackers and cheese

$1 \square$ Celery and peanut butter

$0 \square$ Fruit juice and potato chips

26. Why is breakfast important? Check ALL that apply.

$1 \square$ Helps you learn

$1 \square$ Gives you energy

oDMakes you weaker

$1 \square$ Helps keep you from getting sick

1Helps you think and concentrate

Directions: For the following questions, place an " $x$ " in the box that represents how sure or not sure you are that you can complete each action.

27. How sure are you that you can be physically active every day?

$3 \square$ Very sure

$2 \square$ Somewhat sure

$1 \square$ Not sure at all

28. How sure are you can identify a healthy meal?

$3 \square$ Very sure

$2 \square$ Somewhat sure

$1 \square$ Not sure at all 
29. How sure are you that you can choose a healthy meal at home?

$3 \square$ Very sure

$2 \square$ Somewhat sure

$1 \square$ Not sure at all

30. How sure are you that you can choose a healthy meal at school?

$3 \square$ Very sure

$2 \square$ Somewhat sure

$1 \square$ Not sure at all

31. How sure are you that you can choose a meal with all five food groups?

$3 \square$ Very sure

$2 \square$ Somewhat sure

$1 \square$ Not sure at all

32. How sure are you that you can choose a healthy meal when your friends do not?

$3 \square$ Very sure

$2 \square$ Somewhat sure

$1 \square$ Not sure at all

33. How sure are you that you can plan a meal with at least three different food groups in it? (Remember, food groups include protein, vegetables, fruits, grains, and dairy)

$3 \square$ Very sure

$2 \square$ Somewhat sure

$1 \square$ Not sure at all

34. How sure are you that you can choose a healthy snack?

$3 \square$ Very sure

$2 \square$ Somewhat sure

$1 \square$ Not sure at all

35. How sure are you that you can choose to be physically active instead of playing a video game, watching TV, playing on the computer, or spending time on a mobile device?

$3 \square$ Very sure

$2 \square$ Somewhat sure

$1 \square$ Not sure at all 
36. How sure are you that you can eat breakfast every morning?

$3 \square$ Very sure

$2 \square$ Somewhat sure

$1 \square$ Not sure at all

37. If you are not VERY SURE that you can eat breakfast every morning, why are you not very sure you can eat breakfast every morning? Check ALL that apply.

$1 \square$ No time to eat breakfast

$2 \square$ Trying to lose weight

$3 \square$ I am not hungry at breakfast time

$4 \square$ I do not like the food that is available to eat

$5 \square$ Another reason

$6 \square$ This question does not apply to me; I am VERY SURE that I can eat breakfast every morning

38. Yesterday, I watched the screen (TV, IPad, videogames, cinema, etc.) for:

$4 \square 2$ hours or less

$3 \square 3$ hours

$2 \square 4$ hours

$1 \square$ more than 4 hours

39. How many hours of screen time do you think you shouldn't exceed each day to be healthy?

$1 \square 2$ hours

$0 \square 3$ hours

$0 \square 4$ hours

$0 \square$ screen time has nothing to do with health

40. How sure that you can control your screen time to the recommended amount of time?

$3 \square$ Very sure

$2 \square$ Somewhat sure

$1 \square$ Not sure at all

Thank you! 


\section{استبيان العادات الصحية}

التعليمات: للأسئلة التالية، ضع علامه "x" في المربع الذي يمثل أفضل إجابتك. لا توجد اجابات صحيحة أو خاطئة. اختر اجابة و احدة فقط لانطئن

1. يوم أمس، كم مرة كنت تأكل / تشرب الألبان، مثل الحليب و اللبن و الجبن؟ 口 ولامرة مرة 口 1 مرة 口 2 مرة 3 أو أكثر

2. يوم أمس، كم مرة كنت تأكل الفاكهة الطازجة، المجمدة، المجففة أو المعلبة ؟ (لا تحسب عصير الفاكهة) 口 و لالهرة 口 1 مرة 1 مرة 口 2 مرة مرة 3 أو أكثر

3. يوم أمس، كم مرة كنت تأكل الخضار الطازجة، والمجدة، أو المعلبة؟ (لا تحسب البطاطا المقلية أو الثبس) 口 ولا مرة 口 1 مرة 


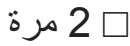

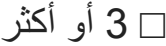

$$
\begin{aligned}
& \text { 4. يوم أمس، كم مرة كنت تأكل البطاطا المقلية، الثبس، البفلك، او الناتشوز؟ }
\end{aligned}
$$

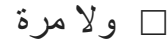

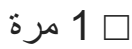

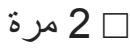

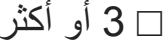

$$
\begin{aligned}
& \text { 5. يوم أمس، كم مرة أكلت الحبوب الكاملة، مثل خبز اسمر، معكرونة سمراء، او بسكوت النحالة؟ }
\end{aligned}
$$

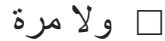

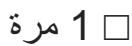

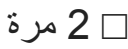

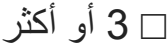

$$
\begin{aligned}
& \text { 6. يوم أمس، كم مرة كنت تأكل البروتين الخالي من الثحم، مثل لحوم البقر و الدجاج و الأسماك البقوليات وزبدة }
\end{aligned}
$$

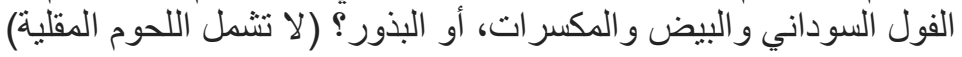

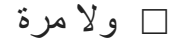

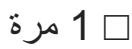

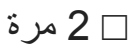

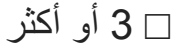

$$
\begin{aligned}
& \text { 7. يوم أمس، كم مرة كنت تشرب أي عصائر، المشروبات الرياضية، أو غير ها من المشروبات السكرية؟ (لا تشمل } \\
& \text { عصير الطبيعي 100٪ أو المشروبات الدايت) }
\end{aligned}
$$

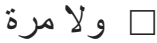

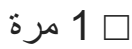

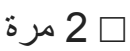

$$
\begin{aligned}
& \text { } 3 \text { أو أكثر } \\
& \text { 8. يوم أمس، كم مرة كنت تشرب أي من المشروبات الغازية مثل الكولا و السفن ...؟ ( لا تشمل مشروبات الدايت) }
\end{aligned}
$$

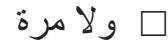

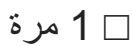

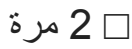

$$
\begin{aligned}
& \text { 口 } 3 \text { أو أكثر } \\
& \text { 10. كم درة تنتاول وجبة الإفطار (الريوق)؟ }
\end{aligned}
$$

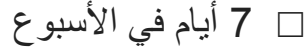

$$
\begin{aligned}
& \text { 6-6 - 5 أيام في الأسبوع الأبوع }
\end{aligned}
$$




$$
\begin{array}{r}
\text { 口 } 0 \\
\text { أيام في الأسبوع الأسبوع في الأسبوع 2-3 } 0
\end{array}
$$

11. كم مرة كنت نشطة جسديا لمدة 60 دقيقة على الأقل يوميا أو أكثر؟ (و هذا يشمل أننطة مثل ممارسة الرياضة،

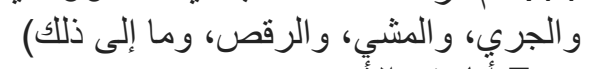

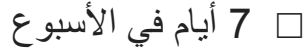

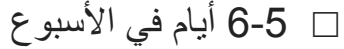

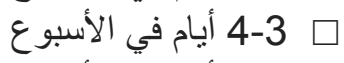

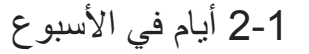

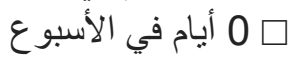

12- كم مرة تساعدون على تخطيط وجبات عائلية في المنزل؟

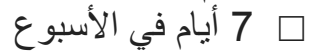

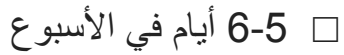

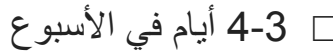

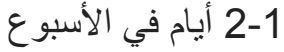

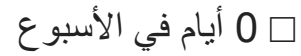

التعليمات: للأسئلة التالية، ضع "x" في المربع الذي بمثل إجابة واحدة تعتقد أنها صحيحة. 13. قد حان وقت الغداء وسارة لديها الاطعمة التالية في حقيبة الغداء: تفاحة، حليب الثنوكو لاتة، روب، والدجاج المشوي. كم عدد المجموعات الغذائية المختلفة في هذه الحقيبة الخبّ

14 - تعتبر الفو اكه والخضروات مصادر جيدة للفيتامينات. صحيحة أو خاطئةج

15. كم عدد دقائق النشاط البدني التي تعتقد أنك تحتاج إليها يوميا لنكون صحي؟

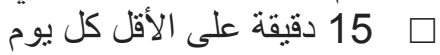

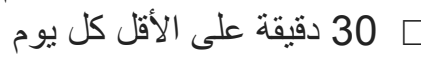

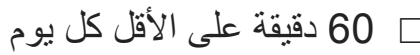
90 دقيقة على الأقل كل يوم بوم

16. لماذا النشاط البدني جيد للأطفال؟

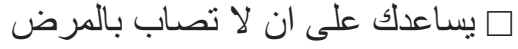




$$
\begin{aligned}
& \text { 口 بساعدك على الانتباه في المدرسة }
\end{aligned}
$$

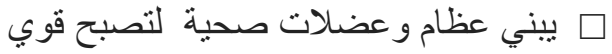

$$
\begin{aligned}
& \text { 口بعطيك طاقة } \\
& \text { 口 كل ما سبق } \\
& \text { 17. ما هي المواد الغذائية التي لِ تنتمي الى مجمو عة الحبوب؟ } \\
& \text { 口 و افل } \\
& \text { 口 معكرونه } \\
& \text { 口 مكسر ات }
\end{aligned}
$$

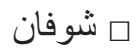

$$
\begin{aligned}
& \text { 18. ما هي المو اد الغذائية التي لِ تنتمي إلى مجمو عة الخضار؟ } \\
& \text { ه بروكلي }
\end{aligned}
$$

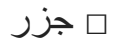

$$
\begin{aligned}
& \text { ه ملفوف }
\end{aligned}
$$

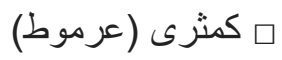

$$
\begin{aligned}
& \text { 19. أي طعام لا بنتمي إلى مجمو عة الفاكهة؟ } \\
& \text { ه فراولة }
\end{aligned}
$$

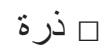

$$
\begin{aligned}
& \text { 口 أناناس } \\
& \text { 口 بطيخ انتانغ } \\
& \text { 20. ما هي المواد الغذائية التي لا تنتمي إلى مجموعة البروتين؟ } \\
& \text { 口 سمك ما ها } \\
& \text { 口 دجاج } \\
& \text { 口 بطاط } \\
& \text { 口 لحم بط } \\
& \text { 21. ما هي الأغذية التي لا تنتمي في مجموعة الألبان؟ } \\
& \text { 口 جبن } \\
& \text { ه بسكوت } \\
& \text { 口 البن } \\
& \text { ه روب لبن }
\end{aligned}
$$

$$
\begin{aligned}
& \text { 22. كم العدد الكلي لأكواب الفواكه و الخضار يجب أن تأكل كل يوم؟ }
\end{aligned}
$$

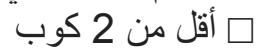

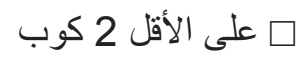

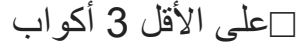

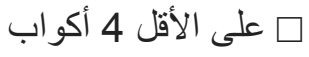

23. كم عدد الاكو اب التي يجب أن تتناولها من مجموعة الألبان كل يوم؟ 


$$
\text { 口 } 1 \text { أكواب } 1 \text { كوب }
$$

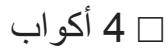$$
\text { أكواب } 5
$$

$$
\begin{aligned}
& 24 \text { - اي طعام بعتبر من الحبوب الكاملة: } \\
& \text { 口 شوفان }
\end{aligned}
$$

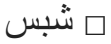

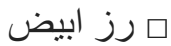

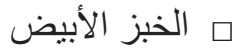

التعليمات: للأسئلة التالية، ضع "x" فى المربعات التى تمثل جميع الإجابات التى تعتقد أنها صحيحة.

$$
\begin{aligned}
& \text { 25. أي من الخيارات التالية سيكون خيار اصحيا لتناول وجبة خفيفة؟ اختر جميع الاجابات الصحيحة. } \\
& \text { 口 الفو أكه و الزبادي الخياري }
\end{aligned}
$$

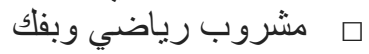

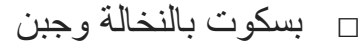

$$
\begin{aligned}
& \text { ه ت تفاحة و زبدة الفول السوداني (peanut butter) }
\end{aligned}
$$

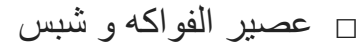

26. لماذا الإفطار (الريوق) مهم؟ اختر جميع الاجابات الصحيحة.

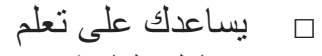
بعطيك الطاقة 口 يجاعلك كسول

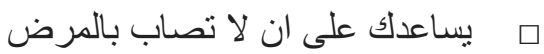

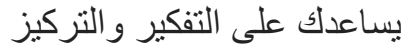

إجراءئ. التعليمات للأسئلة التالية، ضع علامة "x" في المربع الذي يمثل مدى تأكدك أو عدم تأكدلك من أنه يمكنك إكمال كل

27. ما مدى تأكدك من أنك يمكن أن تكون نشطة جسديا كل يوج؟

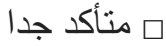

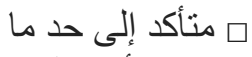

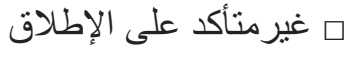

28. ما مدى تأكدك من مقدرتك على التعرف على الوجبات الصحية؟

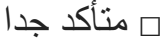

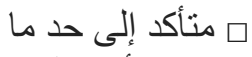

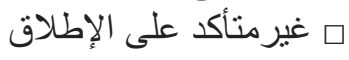

29. ما مدى تأكدك من نك يمكن أن تختار وجبة صحية في المنزل؟

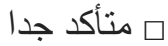

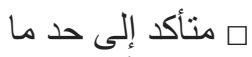

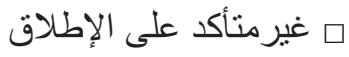


30. ما مدى استعدادك لاختيار وجبة صحية في المدرسة؟ 口 منأكد جدا

口 متأكد إلى حد ما

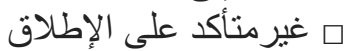

31. هل أنت متأكد من أنكأك تسنطيع أن تختار وجبة مع جميع المجموعات الغذائية الخمسة؟ 口 منأكد جدا

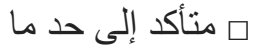

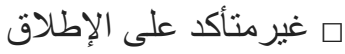

32. هال أنت متأكد من أنك يمكن أن تختار وجبة صحية عندما يختار أصدقائك وجبات غير صحية؟ 口 منأكد جدا

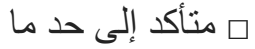

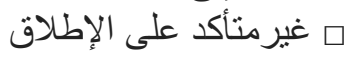

33. هل انت متاكد بمقدرتك لتخطبط وجبة تحتوي على ما لا يقل عن ثناث مجمو عات غذائية مختلفة؟ (تذكر أن

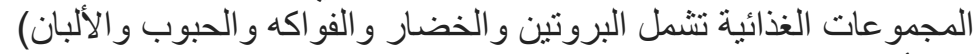
口 منأكد جدا

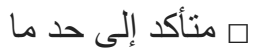
口 غيرمتأكد على الإطلاق مع مأل

34. ما مدى تأكدلك من أنك تسنطيع اختيار وجبة خفيفة صحية؟ 口 منأكد جدا

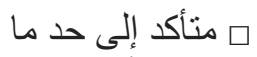

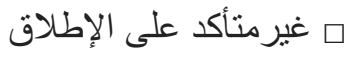

35. ما مدى تأكدك من أنه يمكنك اختيار النشاط البدني بدلا من تشغيل لعبة فيديو أو مشاهدة التلفزيون أو اللعب

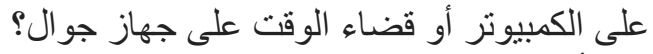
口 منأكد جدا

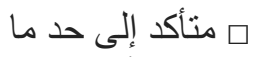
口 غيرمتأكد على الإطلاق مع مأل

36. ما مدى تاكدك لتناول وجبة الإفطار كل صباح؟ 口 منأكد جدا

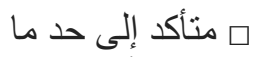

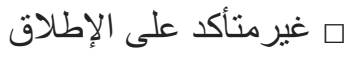

37. إذا لم تكن متأكدا من أن يمكنك تناول وجبة الإفطار كل صباح، لماذا أنت لست متأكدا بانه يمكنك تناول وجبة

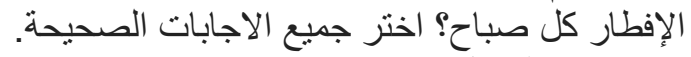
口 لا وقت لتناول وجبة الإفطار

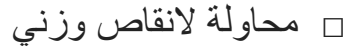
口 أنا لست جائعا في وقت الإفطار 口 لا أحب الطعام الذي يقدم في وجبة الافطار 


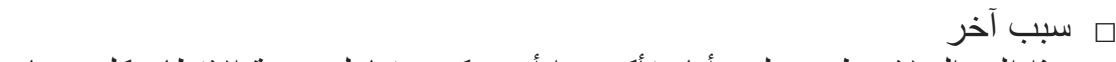

$$
\begin{aligned}
& \text { ه هذا السؤال لا ينطبق علي. أنا متأكد جدا أن يمكني تناول وجبة الإفطار كل صباح } \\
& \text { 38. يوم أمس، شاهدت الثاشـه (التلفاز، الايباد، الالعلي الاكترونيه، سينما، الخ) } \\
& \text { 口 ماعتين او اقل }
\end{aligned}
$$

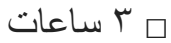

$$
\begin{aligned}
& \text { 口 } \\
& \text { ه اشاهد بقدر ما اريد } \\
& \text { 39.كم ساعة من وقت الثانشة تستطيع المشاهدة كل يوم؟ } \\
& \text { 口 ساعتين او اقل } \\
& \text { 口 r ساعاع } \\
& \text { 口 ع ساعات } \\
& \text { 口 اثناهد بقدر ما اريد } \\
& \text { 40. ما مدى تاكدك من استطاعناك بالتحكم بوقت الثشاشه بالوقت الموصى به؟ } \\
& \text { 口 متأكد جدا } \\
& \text { ه متأكد إلى حد ما }
\end{aligned}
$$

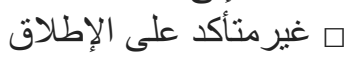

VITA

\section{GHANIMA ALABDULLAH}

\section{Education}

August 2004 - January 2009 Bachelor in Nutrition at Kuwait University, Kuwait

July 2010 - August 2013 Clinical dietitian, Food and Nutrition Department, Ministry of Health, Kuwait

August 2013 - April 2015 Masters in Dietetics and Nutrition, Florida International University, Miami, Florida 
$2013-2018$

August 2015 - April 2018
Recipient of Ministry of Health Scholarship, Kuwait

$\mathrm{PhD}$ candidate in Dietetics and Nutrition, Florida

International University, Miami, Florida

\section{PUBLICATIONS}

Ghanima Alabdullah, Joan Vaccaro, Deborah Abel, Lemia Habib, Fatma Huffman. Kuwaiti Mothers' Perception of Their Child's Body Mass Index and Their Belief in Early Childhood Dietary Advice. Curre Res Diabetes \& Obes J. 2018; 6(4): 555693. DOI: 10.19080/CRDOJ.2018.06.555693005

Alabdullah G, Abel D, Shaban L, Fatma Huffman: Kuwaiti Mother's Perception of Her 35 Year Old Child's Body Mass Index. Experimental Biology, San Diego, California, 2016

Alabdullah G, Sneij A. Fast-Paced Society: Influence of Societal Structure on Eating Habits and Physical Activities. Graduate Student Appreciation Week, Miami, Florida, 2016.

Alabdullah G, Abel D, Shaban L, Huffman F: Kuwaiti Mother's Perception of Her 3-5Year-Old Child's Body Mass Index. Kuwait International Conference on Life Science, Kuwait, 2017.

Alabdullah G, Huffman F, Campa A, Coccia C, George F, Shaban L: Promoting healthy eating habits among school-aged children in Kuwait - "My Healthy Habits Summer Camp". Future of Food and Nutrition, Boston, Massachusetts, 2018. 